\title{
A MIRROR OF SOCIETY: \\ FEMINIST ADVOCACY IN EMILIA PARDO BAZÁN'S SHORT STORIES
}

By

Patricia J. Ramsay

\begin{abstract}
A Thesis
Submitted to the Victoria University of Wellington in fulfilment of the requirements for the Degree of

Master of Arts in Spanish
\end{abstract}

Victoria University of Wellington

2018 


\begin{abstract}
This thesis is concerned with the manner in which the fin de siècle Spanish writer Emilia Pardo Bazán (1851-1921) disseminated her feminist views through her short stories published in popular newspapers and journals. As a female writer, she incurred the ire of many of her male contemporaries, challenging them both personally with her feminist views, and professionally, with her erudition and immense literary output. In this thesis I offer firstly an overview of Spanish society during Pardo Bazán's lifetime with particular reference to the situation of women and go on to outline her life and most significant achievements, literary and otherwise, with a view to contextualising the narrative analysis which follows. Twelve of Pardo Bazán's selected short stories are analysed in the light of the feminist topics which she addressed in several of her essays and, where possible, I correlate these stories with the relevant essays. In particular, I examine issues of female literacy, legal rights and prostitution, as well as the gendered double standards of the time in the area of religious observance and, in particular, the double moral standard. I also examine stories where women did exercise a degree of agency and act in ways that went against patriarchal standards of behaviour, making life-changing decisions. I argue that in these twelve stories, it is evident that not only is each one able to be read as seemingly conforming with the mores of the patriarchal society, but that each one also has a veiled subtext where the injustices suffered by the female protagonists are made evident. Thus, I show that these stories align with Pardo Bazán's essays and promote her broader feminist views to the reader willing to consider them.
\end{abstract}




\section{Acknowledgements}

I would particularly like to like to thank Nicola Gilmour, my supervisor, for the help that she has given me as I have planned and written this thesis. I appreciate her knowledge and judgement, the support that she has shown for my ideas, her (always polite!) criticism of my work and, above all, her encouragement. Thanks also to Laura Holcroft, my first Spanish teacher, who introduced me to Spanish short stories, and last, but certainly not least, to my husband Ian, who has been so understanding and helpful as I have completed this work. 


\section{Table of Contents}

Abstract

Acknowledgements iv

Index $\quad \mathrm{V}$

Introduction 1

Chapter 1: Emilia Pardo Bazán’s Fin de Siècle Spain 9

Chapter 2: Emilia Pardo Bazán: Life and Works 31

Chapter 3: Alone and Destitute 57

Chapter 4: Un Monstruoso Jano 81

Chapter 5: A Mind of Her Own 99

$\begin{array}{ll}\text { Conclusion } & 127\end{array}$

Bibliography 133

$\begin{array}{ll}\text { Appendix } & 141\end{array}$ 



\section{Introduction}

Galician author Emilia Pardo Bazán, (1851-1921), “is one of the most important literary figures of nineteenth century Spain [and] without doubt the most influential Spanish women writer of that century" (Tolliver Torn ix). Her literary output was prolific. She published twenty novels, twenty-one novellas, seven plays, two cookbooks, dozens of essays on a wide variety of subjects, and, most importantly for the purposes of this thesis, almost six hundred short stories. Most of the scholarly criticism of Pardo Bazán's writings has centred on a few of her naturalistic novels and a set of collected essays, La cuestión palpitante, from the late 1880 . Despite the number and literary quality of her short stories, there has only been sporadic interest in them, much of it from a small group of American researchers in the late twentieth century. And, following the same pattern as the criticism of Pardo Bazán's novels, much of the short story criticism has been focussed on relatively few narratives.

Pardo Bazán was a strong advocate for the equality of women in Spanish society. In this thesis I have selected twelve of her short stories and I will analyse the way in which they reflect the feminist views which she expressed overtly in zmany of her essays. Maryellen Bieder argues that the female characters in the majority of Pardo Bazán's most famous novels tend to reinforce and affirm existing patriarchal social values (“Authority” 473). ${ }^{1}$ However, I will argue that this is not the case in many of her short stories, including the twelve examples

\footnotetext{
${ }^{1}$ A striking exception to this statement is Memorias de un solterón (1896).
} 
analysd below. A number of the stories that I examine portray strong female characters willing and able to challenge and subvert patriarchal society. However, others highlight the injustices that women endured in Spanish patriarchal society of the time and the stories often convey a subversive feminist message. By presenting her argument to the mainly male readership in newspapers and journals, Pardo Bazán was in fact indirectly advocating for social change for Spanish women. I am drawn by the subversiveness and the forcefulness of the feminist message in these stories; the majority allow a reading which can be seen in some way to conform to the patriarchal mores of the society, while at the same time lending themselves to another, less obvious, feminist reading. Given the dearth of criticism existing on Pardo Bazán’s short stories, my work provides a different perspective on the stories I have selected, some of which have not been studied before in any depth.

The first chapter of my thesis will briefly examine Spanish society and politics during Pardo Bazán's lifespan, with a sub-section on the expected gender roles for the middle class at that time, and particular reference to the figure of el ángel del hogar. This focus on the middle class is important because the majority of the protagonists in these stories are from this sector of society, as was Pardo Bazán’s readership. In 1859 María del Pilar Sinués published El ángel del hogar, which became the "standard" that detailed acceptable behaviour for the ideal Spanish middle-class woman: a perfect wife and mother, submissive, pious, obedient to her husband and forgiving of any of his infidelities. A woman's whole upbringing was focussed on this one objective. Spanish men, on the other hand, operated according to a double standard; they were free to be impious and to 
have affairs, while demanding that their wives remain meekly at home, educating and instilling piety into their children (although women's own education was often rudimentary). Other social issues relevant to the short stories in the later chapters will also be covered, such as the slow development of female education in Spain and legal questions, including the women's lack of rights and divorce.

Pardo Bazán was a woman who held very definite opinions on a variety of moral, legal, educational, literary and philosophical matters. She condemned the widely accepted "doble moral" in essays and was forthright in her defence of women's rights-equality in marriage, the right to an education equal to that received by males, and the right to a public place in Spanish society for those women who desired it.

As Pardo Bazán's views, in most respects, were in direct opposition to Sinués’s widely accepted model of the ángel del hogar, I will examine her stance on these issues in Chapter 2 through an examination of her life, philosophy and her literary works. I pay particular attention to her essays, in which she presents her ideas in a straightforward and direct manner, rather than through the more indirect channel of a fictional character or narrator, although there will be some references to her other works in the thesis.

The essays I refer to expound many of Pardo Bazán's ideas and observations on the place of women in fin de siècle Spain, including the social status of married women, the religious and moral education which women received and on their inferior general education. They include "The Women of Spain" (1889) which first appeared in English in a London publication and the next year was serialised, with some amendments, as "La mujer española" (1890) in 
La España Moderna, as well as “La cuestión académica” (1891), "Sobre los derechos de la mujer" (1901) and "La educación del hombre y la de la mujer" (1892). In addition, this chapter includes a more substantial introduction to her short stories and the way that Pardo Bazán used some of these stories to represent the reality of contemporary life for many of the women of her timeboth middle-class and working-class-in order to advocate indirectly to her readers for social change that would grant women's basic freedoms and rights.

I argue that each of the twelve selected stories can be read as having a feminist sub-text and Chapters 3, 4 and 5 of the thesis show how Pardo Bazán in these short stories represented the life of many Spanish women, with all its hardships and gender-based injustices. Undoubtedly, there must have been many couples where both were comfortable with the ángel del hogar ideal. However, with one exception, none of Pardo Bazán’s protagonists in this thesis could be described as fulfilling this ideal. Some were impoverished rural women, some had been badly treated or betrayed by their husbands, fiancés or fathers, and others were the victims of suddenly altered circumstances that particularly affected them as women.

Each of the narratives illustrates and problematises different aspects of the difficulties which faced many Spanish women, and their families, during the Pardo Bazán's lifetime. The social "superiority" and rights of the male are evident in the stories, and many of them emphasise women's absolute lack of agency in both the private and public spheres. The suffering of women, resulting from this lack of agency, whether physical, mental or emotional is a recurring theme in these stories. Pardo Bazán recognised and made public this suffering in her 
society, and, to quote Donald Brown, "thought that there could never be anything wrong with saying the truth about things, however painful it was to hear" (40). As Pardo Bazán initially published her stories in various magazines, such as Blanco y Negro, El Imparcial, El Liberal, La España Moderna and Sudexprés, (with a mainly male readership) her points were being made directly to the sector of society who were able to implement change, if they so wished.

Female agency and the spiritual and moral double standards that were widely accepted in nineteenth-century Spanish society are the two issues around which I have structured these three chapters. The question of agency is discussed to a greater or lesser extent in all but one of the stories, and double standards feature in many. Most stories address more than one social issue and several stories would arguably fit equally well into a different chapter. However, I have organised them into three chapters as follows.

Chapter 3 examines the plight of women without agency and without adequate means of self-support. A middle-class married woman, although poorly educated, "trapped" in her own home under her husband's emotional and social control was at least financially provided for. The fate of many women without education, without money and without agency, who needed to find their own way in the world, however, was dire. Pardo Bazán’s narratives, in general, offer the reader a sympathetic view of such women. For women without some education, employment was often difficult to obtain; housekeeping, manual labour or prostitution were the most common options.

"El indulto" (1883), is the story of a destitute rural mother desperate to protect herself from the violence that her imprisoned husband has vowed to 
inflict on her upon his release and the helplessness of women, due to the lack of legal services available to them, is highlighted in this tale. "Champagne" (1898) and "Náufragas" (1909) illustrate the speed with which a woman's circumstances can change, leaving her penniless and with prostitution as seemingly the only option. "Las medias rojas" (1914) touches on emigration as a possible solution to avoiding a future life of poverty and, like "El indulto", illustrates the physical violence that many working-class women suffered within the domestic sphere. These two stories also reveal that any illusions of female agency entertained by poor illiterate women are exactly that. In their world, the male will almost invariably win.

In Chapter 4 I analyse the selected stories in the light of the gender double standards that existed in Spanish society. It begins with "Los huevos pasados" (1896), which illustrates, in a humorous way, the double standard of religious observance that existed between men and women-an open secret in society. Far more insidious, however, was the moral double standard featured in the other two stories, "Sor Aparición" (1896), and "La culpable" (1898), whereby men were not bound to respect single marriageable women, nor bound to fidelity within a marriage or engagement period, whereas the punishment for women in such circumstances was severe. "La culpable" also illustrates the destructive power that a bullying husband could wield over his wife and the burden of guilt which the woman bore as a result of any moral slip. El qué dirán, Spanish society’s communal "watchdog", is also seen to be firmly aligned to the male advantage. Chapter 5 examines five stories of women who do act for themselves and break from the expected behaviour pattern in order to further their own interests 
in one way or another. Two stories feature humiliated wives: "Feminista" (1909) examines a reversal of the masculine/feminine power structure within marriage, (supposedly in private); and "Paracaídas" (1910) is a story of planned public revenge for marital unfaithfulness. The final trio of stories centre on weddings: "La novia fiel" (1894), in which the fiancée chastely waits nine years for her unfaithful fiancé but eventually calls the relationship off; "El encaje roto" (1897), where the bride makes an unexpected and life-changing decision on her wedding day; and "La boda" (1909), in which a reluctant bride is able to make a splitsecond decision shortly after the wedding ceremony, thus giving herself some chance of ensuring her future happiness.

In this thesis I will examine the ways in which Pardo Bazán used her essays to identify gendered injustice in her society and I will show how these particular short stories reflect and represent these injustices suffered by women. As each of the twelve stories is analysed, Pardo Bazán's literary style and her use of narrative techniques will be discussed and it will be shown that in each one Pardo Bazán has created the situation where a reading against the grain reveals a narrative which expresses a feminist subtext, sometimes overtly, sometimes in a subversive manner. 


\title{
Chapter 1: Emilia Pardo Bazán’s Fin de Siècle Spain
}

\author{
"La cuestión de la enseñanza feminina en la España \\ decimonónica no se centra, como en otros países más \\ industrializados de la época, en el acceso de la mujer \\ a la universidad sino en la escolorización de las niñas." \\ -Catherine Jagoe, "Enseñanza"
}

\section{Introduction}

Emilia Pardo Bazán’s lifetime, from 1851 until 1921, spanned a particularly tumultuous time in Spain's history. The stability, wealth and territorial gains of $E l$ Siglo de Oro (1500-1700) had long gone, and the next century or so of European warfare and the Napoleonic invasion of Spain left the country struggling well into the nineteenth century. During this century much of Spain became caught up in a vicious cycle, with lack of education, poverty, and slow economic growth all eventually leading back to impoverishment for millions of Spaniards (Gabriel Tortella Casares 19).

This chapter provides an overview of Spanish history and society between the early nineteenth century and the first two decades of the twentieth century. Spanish political developments and the prominence and influence of the Catholic Church in Spanish society will be briefly discussed. However the main emphasis will be on social issues, particularly those which affected women, such as education (or, for girls, the lack of it), legal matters such as divorce, and the moral double standard which became an accepted part of Spanish patriarchal society. Middle-class women were relegated to the domestic sphere, in conformity with the Angel in the House construct which was popularised in the 
185os. Only a very few Spanish women made a name for themselves by rebelling against this, as I will discuss.

\section{Politics}

Spanish Liberalism, a reaction to historic monarchist absolutism, appeared during the post-Napoleonic period. It was loosely based on the philosophies of the English and French Revolutionaries embracing national sovereignty, checks on royal power and the lessening of aristocratic privileges and also included a nostalgic mythology which idealised the Middle Ages. José Álvarez Junco argues however that there was a particular feature of Spanish liberalism in relation to the Catholic Church that was unique among the European Catholic countries. It is the notion, stated in article 12 of the 1812 Constitution, drawn up by the Cortes of Cádiz that "the official, state-sanctioned religion of Spain is and always will be Catholic, Apostolic, Roman, only true one” (26). Spain’s Liberal Catholicism did not include religious tolerance, in sharp contrast to the French declaration of 1789 that "no one can be harmed on account of their opinions, including religious ones" (26). Apart from the six years of the Glorious Revolution (1868-74) the influence of the Catholic Church in Spain was all-pervading and was also instrumental in upholding the patriarchal status quo. We will see this point being particularly pertinent later in several of the stories, and also in relation to Pardo Bazán herself as she maintained a strong Catholic faith throughout her life.

The succession to the Spanish throne was contested in the 1830 and resulted in the Carlist Wars, originally in the 1830 and again in the 1870 . Fernando VII of Spain (1784-1833), whose reign "was marked by brutality and 
mediocrity in high places", left no male heirs, and on his death the heir to the throne was his daughter Isabel II, aged three (Vilar 58). His Queen, María Cristina, was appointed Regent until Isabel was of age. However, his political opponents had placed their support behind his brother, Carlos de Borbón (Carlos V), not wishing to see a woman ascend to the throne. Both times their cause was defeated (Vilar 58). The northern rural gentry, (including Pardo Bazán’s family and her husband) tended to be Carlist supporters; indeed Pardo Bazán herself had once taken part in their activities (Pattison 18).

In 1843 Isabel reigned directly, aged thirteen. She was not a popular queen but remained on the throne until she was deposed and forced into exile in France at the beginning of the Glorious Revolution of 1868. Two years later she abdicated in favour of her son Alfonso XII, although he did not take the throne until 1874. An Italian, Amadeo, Duke of Acosta replaced her on the Spanish throne from 1870 until 1873, at which time the Spanish Cortes proclaimed a Republic which lasted into 1874. Tortella Casares sums up nineteenth-century Spain to this point as having "existed in a state of latent turmoil", with de facto power in the hands of the various military groups (27).

This Revolution of 1868, which led to the Sexenio Democrático [six years of democratic rule], caused the balance of power to shift dramatically against the church with the outcome being an anticlerical and progressive backlash against the reactionary politics of Queen Isabel II (Carr 310, 286). The Constitution of 1869, which incorporated universal suffrage, ${ }^{2}$ religious freedom, the legality of

\footnotetext{
${ }^{2}$ The voting age was fixed at 25 , and "universal" in reality meant "male". Female suffrage was not officially adopted until 1933 during the Second Republic (Carr 310; Vilar 92).
} 
civil marriage, the jury system and freedom of the press (all on the Democratic agenda), was accepted (Carr 310). Although the Republican Party envisioned radical changes in society, it was neither strong nor united and, consequently, it was overthrown by monarchists in December 1874 before the Constitution could become a reality, and Alfonso XII finally became king.

The Restoration of the monarchy, under the guidance of the Prime Minister Antonio Cánovas del Castillo, returned Spain politically to the pre-1868 status quo. Newly-gained Republican reforms such as the legality of civil marriage were repealed, and a resurgent Catholicism dominated all facets of Spanish life. The Spanish catch-cry "España será católica o no será" reflected the mood of this Restoration period (Townson 74-75). Nevertheless, the anticlerical movement was never totally extinguished during the Restoration. It was somewhat revived by Spain's defeat by the US in 1898, "El desastre"3 and it reached a climax a decade later with La semana trágica in Barcelona in 1909, when half of the city's religious buildings were burned and 118 people died during a week of radical and anti-clerical violence (Townson 79).

During Cánovas's time as Prime Minister from 1874-188o he endeavoured to establish a stable monarchical constitution that embraced all Spaniards by devising an artificial two-party system, the turno pacífico. The Liberal and Conservative parties alternated in office, with the expectation that conflict between the parties would diminish and a "peaceful co-existence" would prevail (Carr 348-49). The caciques controlled the election, and the election results, by

\footnotetext{
${ }^{3}$ As a result of this defeat Spain lost her last colonies. Cuba became independent and Puerto Rico, Philippines and Guam's governance was ceded to the United States (Carr 379-388, Vilar 73).
} 
exerting their personal influence on voters. Overall, the turno pacífico, provided a surprisingly stable period of government until well into the 1890 s. Despite the increasing instability that developed in Spain after that time, the monarchy itself and the turno system of government would remain in place until the Primo de Rivera regime of 1923 (Carr 523), events which Pardo Bazán did not live to see.

\section{Social Issues}

\section{Education and Literacy}

At the beginning of the nineteenth century the Spanish education system, which, according to Tortella Casares, "was in a shambles from the seventeenth century onwards", collapsed completely. Catherine Jagoe reports that in 1803 only $5 \%$ of Spaniards were literate ("Enseñanza" 107). In 1813 the Quintana Report was issued, proposing state responsibility for general and free education, but unfortunately this vision was not fulfilled (Tortella Casares 47; Scanlon 16-17). A more successful attempt to re-establish a state education system occurred decades later, in 1857 , when legislators passed the Moyano law education reform, La Ley de Instrucción Pública. This law stated that children were to attend school from the ages of six to nine, although there was a great deal of uncertainty as to whether the word niños included girls (Jagoe "Enseñanza" 115).

It was more than a decade later, in 1868 , until an effective education system became established, but it was only able to progress during the Restoration period when the Liberals took their turn in power, making its development a slow, drawn-out process (Tortella Casares 47-48). Miguel de 
Unamuno (1864-1936) is reputed to have compared the progress in education with the task of Penelope-weaving and unravelling the same piece of work over and over again (Jagoe "Enseñanza" 106). Mid-century discussions in more industrialised countries, Jagoe observes, were about the right of women to a university education, while Spain at that time was discussing the right of girls to attend primary school in order to receive basic literacy skills ("Enseñanza" 105).

At this time, it was chiefly middle-class children who received a primary education and of these, only 1 in 10 students progressed to secondary school. Only male urban elites attended university and this area is where most government money was spent (Scanlon 49). Separate schools for girls were established in towns with more than 500 inhabitants and smaller towns allowed for one school, but with physical separation of the sexes (Scanlon 17). Teacher training for women was introduced in 1857 although it was described as "inadecuada a todos los respectos" (Scanlon 42). This curriculum specified for the first time the range of subjects that could be taught to boys and girls.

Unsurprisingly, girls were denied the chance to study science or classics, with teachers being instructed to teach girls only "nociones" of academic subjects, making it impossible for them to acquire any true depth (Scanlon 4243). The aim was to educate girls for the fulfilment of their future roles as wives, mothers and genteel members of society (Scanlon 18). Pardo Bazán, however, disagreed strongly with this cursory approach to female education. Her views are illustrated in one of her novels, El viaje de novios (1881), where the protagonist Lucía's "good" boarding school education is described disdainfully as one which allowed her to "chapurrear algo de francés y a teclear un poco en el piano; ideas 
serias, perdone usted por Dios; conocimiento de la sociedad, cero ... alguna laborcita tediosa e inútil, amén de fea" (41). Two short stories that will be examined in this thesis, "El indulto" and "Las medias rojas", highlight difficulties that illiterate women encountered, for example when faced with legal matters, having no option but to accept what they were told by males about their legal rights.

Tortella Casares considers that for a society to move towards modernisation a literate population is essential. He offers three concrete examples of areas in which literacy is important: to expand personal knowledge, to reach higher educational levels, and to operate machinery meaningfully and understand their associated written instruction books (14-15). However, in nineteenth-century Spain the Catholic Church "viewed with alarm the possibility that the faithful laymen ... should learn to read" (17). The Spanish state, he argues, also had responsibilities in this area, which it failed to fulfil, due to a combination of neglect, historical inertia, lack of political pressure and, possibly, insufficient resources. Mass literacy was often neglected in favour of other programmes which produced only short term results (19).

As a result of this lack of attention to education, between 1850 and 1910 Spain had one of the lowest literacy rates in Europe, with only $25 \%$ of the total population being literate in 1850 , and by 1910 still only $50 \%$ of Spaniards were able to read (Tortella Casares 13-14). Geraldine Scanlon asserts that there was little economic pressure, or need, for the majority of Spanish women, who were rural manual labourers, to receive more than the most rudimentary education (5) 
and the literacy rate for women outside Madrid at this time was only about $20 \%$ (Jagoe “Enseñaza” 114).

It must also be noted that the official literacy rates and, indeed, school attendance figures reveal a significant gender differential, with primary schools for girls first established in 1857, and secondary schooling for girls approved eleven years after that in 1868 (Blanco 376). As Oloriz wrote in 1900, "aprender leer y escribir abría las puertas de la seducción, y que las mujeres no necesitaban educación para servir a Dios y cumplir con su obligación doméstica” (cited in Scanlon 49), a statement which underlines the fact that even by the twentieth century the two fundamental problems for female education in Spain continued to be the attitude of the church and that of society.

\section{Slow Economic Growth}

One of the chief obstacles to general economic modernisation in Spain was the lack of agricultural development. This was due, in many cases, to the natural features of the country with its harsh climatic conditions and poor soil. Only Galicia and the northern coastal and the Pyrenean border strips were truly fertile regions. Living and working conditions for millions of campesinos were harsh, with semi-starvation common, and only seasonal employment being available in many areas (Tortella Casares 9-11).

Raymond Carr notes that the late nineteenth century saw a growth in the Spanish population, due to both a dramatic decline in infant mortality and a falling death-rate. The countryside, particularly the provinces of Andalucia, Extremadura and Galicia which, in 1900, comprised 35\% of Spain's population, 
was the worst affected and was unable to support the population growth. ${ }^{4}$ This led to increasing migration from these three provinces in particular. Many moved from the countryside to the cities; others took the opportunity to emigrate to the Americas. In 1913 alone, 134, ooo people left Spain. However the onset of the First World War abruptly slowed this particular exodus (Carr 414, 417). Pardo Bazán’s "Las medias rojas" graphically illustrates the harsh and brutal everyday lives of a typical Galician labourer and his daughter and the reader is left in no doubt as to why emigration appeared to be a popular option for people such as these. However, as the story also illustrates, there were often unforeseen difficulties for illiterate young women who naïvely believed emigration to be the answer to a better life.

\section{The New Century}

The twentieth century, by contrast, saw slow but steady economic growth, with only short-term industrial crises (Carr 389). Tortella Casares notes the sharp contrast in Spain between the slow growth and backwardness of the nineteenth century, measured in terms of the European norm, and its rapid growth in the twentieth century. This new century was a time of profound structural change, industrialisation, and economic development that led to the recovery of much of the ground lost previously (1-2).

The end effect of this slow and sporadic modernisation and industrialisation was that Spanish society itself became fragmented. The small

\footnotetext{
${ }^{4}$ See Tortella Casares Table 2.4 (42).
} 
municipalities were still ruled by the traditional poderosos who flourished personally with their pre-eminence and wealth and maintained tight control on the people within their jurisdiction. The financiers and large-scale industrial entrepreneurs, respectable and solid middle-class citizens, who emerged during the Restoration, became the dominant force of the industrial towns and the banking system. During this time, the conditions of the semi-skilled and unskilled labour force deteriorated, causing a marked class gulf to develop between the newly emerging and affluent middle class, and the lower labouring class, who in many rural areas were still living at little more than subsistence level (Carr 431-34, 438). And of course, the aristocracy, with their substantial landholdings, still wielded social and political influence.

These cultural transformations and fragmentations of Spanish society during the nineteenth century resulted in the "field of human activity" being reorganised into male-centred production and marketing, and the state and government (Kirkpatrick Románticas 3). Women were relegated to a private world of blood or love relationships, far from the rational masculine world of production and politics. The family itself became private and nuclear. From this, the idea emerged (and took hold) that femininity was concerned exclusively with this private world of domesticity (Románticas 3-4) and the social position of the middle-class woman had changed markedly.

\section{The Middle-Class “Angel”}

This "new" position of domesticity was presented to Spanish women in the figure of el ángel del hogar, most notably by Sinués, whose 1859 conduct manual for 
middle-class women of the same title proved so popular that seven reprints were produced in the next thirty years or so. ${ }^{5}$ British, North American and French authors also produced works on this theme, with this phenomenon being described by Jagoe as an international bourgeois mode of thought (Galdós 14-15).

The Angel in the House was a socially constructed model of femininity, based on the supposed absolutes that males and females possess: woman is love, not logic, controlled by emotion rather than reason, dominated by her heart and not her head. The physicians of the time attributed these absolutes to women's physiology. However, they opined that female sexual desire itself was an aberration. The ideal woman, the Angel, was non-sexual, with these natural sexual instincts sublimated, renamed and idealised as the source of motherly love (Aldaraca "Medical" 404-05). Aldaraca further argues that such socially constructed categories operate "in the realm of ideology to exercise control over the categorised group by those who define the category" (410-11). This was certainly true in Spain where this model was directed towards middle-class women and girls. Its effect was a rationalisation of their existing exclusion from the public sphere, their rudimentary education and their exclusion from the professions ("Medical" 410-11).

Spain, however, had had a longer history of this feminine ideal. As early as 1583 Fray Luis de León (1527-91) penned La perfecta casada as a wedding gift for his niece, Doña María Varela Osorio. This work offers advice for a wife, based on Proverbs 31 in the Bible. It emphasises wifely silence, honesty, absolute fidelity,

\footnotetext{
5 Blanco points out that Sinués and others promoted the socially acceptable feminine ideals of domesticity that they themselves did not really live by, since they became professional writers (372).
} 
piety, thrift and lack of vanity, and motherly care of the children, as well as her central place in the home, but not beyond it. The place of the husband in relation to the wife is firmly stated: a wife is a gift from God to the husband. It is her duty to do her husband's bidding (119), and the concluding paragraph assures the reader that a woman who follows the book's teaching will obtain a heavenly reward (152). The reader is left with the overwhelming impression that Fray Luis considered women to be morally, physically, and intellectually inferior to men, and capable of corrupting a man by their mere physical presence in the public sphere (10-11). Fray Luis's opinions were, however, well received, as the original wedding gift essay was later published in book form, and remained popular in Spain for several hundred years.

Bridget Aldaraca, in comparing the sixteenth- and nineteenth-century "ideal women" literature written by "self-proclaimed authorities" (Hogar 27), has identified a shift in the reasoning behind the male rationale for the women's behaviour from the sixteenth-century work of Fray Luis to the nineteenth century. In every era the woman is instructed to be modest, industrious, thrifty and (later) ilustrada, but the nineteenth-century woman's existence "begins and ends at her doorstep"; she is defined "territorially, by the space which she occupies" (Hogar 27).

One result of middle-class women being largely confined to the home was that children could be instructed, educationally and morally by their mother. For girls, however, elementary literacy, sewing, and "a firm indoctrination in Catholic dogma" was considered to be an "adequate female education" (Jagoe Galdós 68). By the nineteenth century this home-based instruction became a new 
justification for women's indispensability within the private sphere (Aldaraca Hogar 55).

Sinués, and other women writers of the period, also presented the woman's role as a spiritual leader within the home. This diffuse and imposible ideal is expressed in a quote from La Moda Elegante Ilustrada, a women's magazine, where A. Pirala writes that a woman is "el vínculo de los más nobles afectos, la reguladora del orden y de la economía, el iris de paz, la inspiradora del contento y bien estar de todos" (Jagoe Galdós 58). Joan Hoffman argues that this superhuman ideal created the social and literary ideal of a delicate, compliant, chaste, reticent and selfless being, but also one who was at the same time weak and repressed; she needed protection, which all too easily became control. The nineteenth-century woman may have been an angel, she states, but she was an “angel without wings” (“Ángel” 28).

"El ángel del hogar” was not a phrase that Pardo Bazán herself used frequently, nor did she subscribe to its values. There was, however, an instance in which she publicly made her negative views on the phrase and its implications very clear. As she delivered a eulogy for her fellow feminist Concepción Arenal (1820-1893) in 1893, she praised her for the way that she understood "cuál es el verdadero obstáculo para que la mujer se transforme y se complete; obstáculo serio y terrible, como que la forma un ideal, el ideal del ángel del hogar" (GómezFerrer 210). The majority of the short stories in this thesis will illustrate in some way the anathema she felt towards the Angel in the House. 


\section{The Legal Position of Women}

Arguably, it is the civil laws singling out women's position and their rights in Spanish society during the nineteenth and early twentieth centuries that provide us with the clearest picture of their subjugation within that society, despite the newspapers of the day constantly reassuring women of their "freedom" (Scanlon 122). Three sets of civil laws in particular impacted on women's obligations and rights (or in many instances their lack of rights). These were the Código Civil (1889), the Códigal Penal (1870) and the Código de Comercio (1885).

Unmarried women had more legal rights than their married sisters. By the end of the nineteenth century they were able to lease or buy property, operate bank accounts, lend or borrow money and make a will. They were legally able to run a business and they could be declared bankrupt. These women had the same filial duties and obligations to their parents as their brothers did, although they continued to be restricted in other areas, particularly where other people were involved. They could not take part in a family council, be named as guardian of a child or be a witness to a will (Scanlon 123-24).

The law, in Scanlon's opinion, discouraged any hint of independence on the part of a woman in these business and family matters, and it was even more restrictive in the public and political arena. All women were denied the right to vote, or to participate in any form of justice or government (125). The reasoning behind these decisions was often tortuous and at times ridiculous. Eduardo Gómez de Baquero, (1866-1929) a noted journalist and literary critic, for example, stated that, as women were not required to do military service, this, in itself, denied them the right to vote, adding that as they were naturally of a nervous 
and frivolous disposition, they would cause instability in the political arena (Scanlon 149-50).

There are wide gender variations, too, in the laws surrounding illegitimacy. A single woman had almost no rights. If a woman fell pregnant as the consequence of rape, and the father was successfully prosecuted, he was only obliged to offer some support and recognise the child if, when he was released from prison, he declined to marry the mother. As Scanlon pointedly notes, there is no mention of the fact that the woman may not wish to marry the man in question! For a conception under less brutal circumstances, the law prohibited any paternity investigations. Thus the mother lacked legal channels to obtain support or recognition from the father. The Spanish law's protection of the man implied that it was the woman who was at fault, and that the pregnancy was her problem (126).

At the moment of marriage, women immediately lost all the rights they had been able to exercise before marriage, a condition Scanlon calls legal slavery (126). Fin de siècle society instilled into girls that marriage was their destiny; for middle-class girls their entire upbringing was focussed on this one event in their lives. Spanish law fully described and supported the submissive role of the wife within the marriage relationship, and specified the penalties for any transgressions. Artículo 57 of the Código Civil instructs the couple: "El marido debe proteger a la mujer y ésta obedecer al marido", leaving no doubt as to the woman's standing in the marriage relationship. Furthermore, Scanlon cites Artículo 603 of the Código Penal, which specifies the infringements of this Civil law leading to imprisonment: the husband will be punished if he physically 
maltreats his wife. However, the wife may be imprisoned, not just for physically maltreating her husband, but for merely insulting him. Two short stories examined in Chapter 5 cover this point-Clotilde, the protagonist of "La feminista" certainly insults her husband, while Celina, the protagonist of "Paracaídas", whose story ends before its outcome is revealed, has dramatic and very public plans to do so also.

Scanlon also cites a further series of laws that sought to undermine the independence of a wife, so that in effect she had no legal existence of her own. She had to adopt the husband's nationality, live where he chose, obtain her husband's written permission (which could be withdrawn at will) to conduct any business, and allow him to manage any personal property that she may have brought into the marriage, such as her jewellery or furnishings, as is illustrated in "La culpable" in Chapter 4. In a case of a husband fraudulently using his wife's assets, the law will protect the husband, on the basis that "todos los hombres son inteligentes y razonables y todas las mujeres frívolas y estúpidas ... y necesitadas de protección" (Scanlon 130).

As harsh as the foregoing cases may seem, for most couples they were not everyday problems. There was a far more insidious and common matter in Spanish society in which the law fully supported the husband — that of extramarital relationships. Artículo 56 of the Código Civil instructs married couples to "vivir juntos, guardarse fidelidad y socorrerse mutuamente";m however, it was not uncommon for a husband to involve himself with another woman while continuing to live with his family. Total marital chastity was nevertheless expected from wives, no matter how unfaithful their husbands were. One 
adulterous lapse on the woman's part provided grounds for both an annulment of the marriage and a prison sentence for the woman. A man, however, had to cause a public scandal as a result of his infidelity before he was similarly punished. Likewise, crimes of passion, which were "not infrequent" according to Scanlon, resulted in short prison terms for males, and lifetime sentences for females (131).

Women were plied with advice from many sources as to how best to respond when they discovered that their husband was being unfaithful to them. For example, Sinués advocates tenderness, dignity and resignation towards their husband, rather than fury (Verdades 123). Doctor Salustio, in a work intended to be read by young girls before they were married, explains to his readers that, while as women, they are "criaturas esencialmente espirituales", their future husbands are "esencialmente carnales", and they will need extra-marital relationships. He adds that "[u]n desliz era comprensible en el hombre, pero una aberración en la mujer" [n.pag.]. Presumably the wife is to remain silent and accept that her husband's behaviour is normal. Thus, it is evident that this moral double standard was a recognised and accepted part of fin de siècle society. "La novia fiel", in Chapter 5 deals with this matter, and we will see that the Church is shown to be accepting of such behaviour. In "Paracaídas" there are examples of both an older woman who upholds Sinués's view of acceptance and resignation, as well as a younger woman who is only too ready to challenge it.

The subject of divorce was raised in 1870, during the Sexenio Democrático. It was a difficult subject in nineteenth-century Catholic Spain where Church teaching stated that marriage, by nature, was a perpetual and indissoluble bond, and divorce would undermine the sanctity of marriage. Public opinion at that 
time was firmly in accordance with the Church doctrine (Scanlon 141; Nielfa 57). When the topic was next raised seventeen years later in 1887 , Luis Larroder addressed the Real Academia de Jurisprudencia y Legislación and vehemently rejected the idea. He described divorce as a protestant heresy, which would, if legalised, invariably provoke scenes of immorality, degradation and vice. And, he added, it would lead to a marital climate of lasting hate and revenge in which nobody was able to pardon or be pardoned. Others added to this argument: $\mathrm{Dr}$ Perujo, a Cathedral Canon stated that, for a woman, it was preferable to suffer in a hard, bitter marriage with an unfaithful husband than to be divorced. Divorce for the woman would necessarily mean eternal punishment, while staying in the marriage would assure her of "recompensa del porvenir" (Scanlon 142). Edmundo González Blanco provided a further argument against divorce; he held the view that Spain was unlike either the United States, where women were not held in any esteem, or France, where, he reported, three-quarters of marriages were ruined by prostitution. In these countries, he said, divorce was a good thing. But Spain was different—special and morally superior-and therefore a country where divorce was not needed (Scanlon 143). Pardo Bazán’s “El indulto”, analysed in Chapter 3, makes it quite clear that in Spain even the threatened wife of a murderer was refused a divorce and required to resume living with him after he was released from prison.

This attitude of the politicians and clergy was affirmed in laws passed in 1889 where the word "divorce" in reality referred to a legal separation, with no right of re-marriage provided for either party. Artículos 104, 107, 68 and 73 of the Código Civil specify that divorce must be based on guilt, and that only the 
innocent spouse is able to sue, the judge alone makes decisions on alimony, and any children are kept under the authority of the innocent spouse (Nielfa 58).

Nevertheless, the difficulty of campaigning in the anti-divorce climate of fin de siècle Spain for absolute divorce laws did not stop one woman in particular from doing so: Carmen de Burgos (1867-1932), a teacher and journalist, often writing under the pseudonym "Columbine". In 1903 she created a daily newspaper survey in her Diario Universal column soliciting views on divorce, a topic which made her the target of a slur campaign in Catholic journals. She approached wellknown figures of the intellectual world (who she knew were in agreement with her views) as well as her regular readers, and collated the replies into a book that was published in 1904. With such a sample of "voters", it was no surprise that there were 1,462 respondents in favour of absolute divorce and only 320 against the idea (Burgos 137). For the next two decades Burgos was at the forefront of the campaign for the right for divorce in Spain. However the legal, clerical and highminded arguments such as those recounted above prevailed, and it was only during the Second Republic (1931-39), that absolute divorce was finally legalised in Spain. ${ }^{6}$

\section{Battling the "Angel"}

In 1904 Virginia Woolf wrote that "it was harder to kill a phantom than a reality" and that "[k]illing the Angel in the House was part of the occupation of a woman writer" (238). However, there were, in fact, a handful of Spanish women writers

\footnotetext{
${ }^{6}$ When the Nationalists gained power after the Civil War the laws permitting civil marriage and divorce were repealed. It was not until 1981 that absolute divorce was once again legally available (Glos 669).
} 
who had already realised this by the late nineteenth century, daring to present feminine models outside the "angel" mould, with Faustina Sáez de Melgar (18341895) among the first. In one of her novels, El hogar sin fuego (1876), Julia, the protagonist, laments her lack of education. This lack has led to her inability to obtain the employment she needs in order to provide for her family. As Julia loses her sanity at the close of the novel, Sáez makes it clear to the reader that it is society and its laws that are to blame for her downfall (Blanco 377).

Arenal carried the battle for women's education and employment a step further. Despite the protests of her family, (who were fearful of the disgrace that it would bring to them), Arenal dressed as a man and enrolled in the Law Faculty at the Central University in Madrid. Her future, however, was as a writer and as a social reformer, addressing women's issues in a systematic, consistent way, always based on a sense of justice (Hernández 30). In La mujer del porvenir (1861), she states that "[q]ueremos para la mujer todos los derechos civiles. Queremos que tenga derecha á ejercer todas las profesiones y oficios. ... Nada más. Nada menos" (132-33); she fought for these objectives for the rest of her life. Her second book, La mujer de su casa (1881), discusses working conditions for women and also argued that women had the ability to succeed in a variety of jobs outside the home. Arenal's essays enabled her to express her opinions publicly and forcefully. In "Estado actual de la mujer en España" (1884) Arenal presents a wideranging analysis of the effects of Spanish society's oppression and belittling of women, and in "El trabajo de las mujeres" (1891), she advocates both for better working conditions for women, and for equal pay for equal work when performing the same tasks as men. "La educación de la mujer" (1896) called for a 
comprehensive education for women, beginning with the argument that, perhaps, because of the great number of tasks that a woman was obliged to complete in a day, she needed more education than men, rather than less (Arenal “La educación” n.pag.).

Three other literary women stepped away from the socially expected “angel” model: Rosario de Acuña (1851-1923) and Concepción Gimeno de Flaquer (1860-1919), although the latter was not in favour of women's suffrage, fearing that any foray into the political scene would corrupt women in the same way that the men had been corrupted (Scanlon 151), and Emilia Pardo Bazán. A strong advocate for women's rights, particularly in the fields of education and equality within marriage, Pardo Bazán’s significant contributions in these areas will be discussed in some detail in other sections of this thesis. However, all three women were speaking and writing as concerned individuals. There was no organised feminist movement in Spain comparable to the feminist groups in the United States, Britain or many European countries. Michael Ugarte presents an important reason for this national difference: that Spanish feminism has had to contend constantly with the authority of the Catholic Church, an institution which has always resisted feminist reforms. In Spain, he argues, women had become the ideological property of the Church hierarchy (62).

Scant progress was made in collective female political activity until 1918 when a number of women's associations were formed. The Asociación Nacional de Mujeres Españolas (ANME), which had a middle-class membership base, was particularly far-reaching and influential. Scanlon comments that the ANME, although rooted firmly in the Catholic tradition, was able to maintain an 
independent stance and avoided collaboration with organisations that appeared to defend women's rights, but which in reality defended their own religious interests. Despite the wide range of its programmes, the organisation managed to avoid becoming either anti-Catholic or too radical. Little change was evident, however, until after the formation of the Second Republic in 1931, a period beyond the scope of this work (206).

It can be seen, then, that for the majority of Spanish women very little changed for them in the years between 1850 and 1920. Basic primary-level education was more accessible. However secondary education was for a minority and education at tertiary level was still out of reach. Absolute divorce and female franchise were still years away. Middle-class women had little personal agency, subject to the strictures of the ángel del hogar construct, submissive to their husbands and tolerant of the moral double standards that prevailed.

We have seen that there were some women who did rebel and spent their lives advocating for change for themselves and their sisters, raising awareness of feminist issues in the society of their day. Pardo Bazán, in particular, thrust herself to the forefront of these issues, and it is her life, polemics and writings that the rest of this thesis will be concerned with. She made her feminist views clear in her essays and created plots in many of her short stories which alluded, either directly or indirectly, to the lack of rights, agency and freedom for women in fin de siècle Spain. The following chapter will detail Pardo Bazán's life, ideas and literary output and in the remaining chapters, the dozen short stories I have selected will be analysed. 


\title{
Chapter 2: Emilia Pardo Bazán: Life and Works
}

\author{
"No estamos ante una escritora plana ni univocal, \\ sino ante un carácter inquieto que demuestra \\ fehacientemente su deseo de abarcar muy \\ diversas parcelas del mundo social y literario." \\ -Ángeles Quesada Novás, \\ El amor en los cuentos de Emilia Pardo Bazán
}

\section{Her life}

Emilia Pardo Bazán y de la Rúa-Figueroa was born in La Coruña, Galicia, on 16 September 1851 to José María Pardo Bazán y Mosquera and Amalia de la Rúa y Somoza, and died on 12 May 1921 in Madrid. In "Apuntes autobiográficos", published in 1886 as a prologue to the first edition of Los pazos de Ulloa, Pardo Bazán describes her early life in a moneyed, upper middle-class family. She was an only child, self-contained and somewhat lonely, spending her early years in one or other of the three family homes. Two were in Galicia-el Pazo de Meirás near La Coruña and an estate at Rías Baixas in Pontevedra-while the third was in Madrid.

She was surrounded by adults, and took delight in the various libraries of the family homes. In "Apuntes autobiográficos" she discusses her introduction to literature from the age of five, becoming an avid and eclectic reader by her teens. Each summer was spent at el Pazo de Meirás, where Pardo Bazán immersed herself in the library, permitted to read whatever she chose, except for the French Romantics. However, she unashamedly “appropriated” a copy of Victor Hugo's Notre-Dame de Paris, from a friend's family home, to read later by candle-light (“Apuntes” 25). 
Her father was determined that his daughter would have as extensive an education as was possible for a girl at that time, believing that women were the intellectual equals of men, and should be given every opportunity to reach their potential, an attitude for which Pardo Bazán repeatedly expressed her gratitude (Gómez-Ferrer 16; Alberdi 24). The family spent the winters in Madrid, and for three years Pardo Bazán was enrolled in a French-speaking Ladies' Academy where she received a standard education for a girl of her social standing (Hemingway 163).

Suddenly, at sixteen years of age, her childhood was over. She comments of that year: "Tres acontecimientos importantes en mi vida se siguieron muy de cerca: me vestí de largo, me casé, y estalló la revolución de Septiembre de 1868” (“Apuntes” 26). Her husband, José Quiroga y Pérez de Deza, was nineteen years old and a law student belonging to one of the most eminent families in Galicia, a fellow Carlist sympathiser and, in her parent's eyes, a "highly suitable match" (Hemingway 163; Bravo-Villasante 26-27). The marriage, which took place at Pardo Bazán’s family home in Meirás, was agreed to by both sets of parents and the couple happily accepted the arrangements. After a European honeymoon they continued to live in Galicia until 1869, when they moved, with Pardo Bazán's parents, to Madrid (Alberdi 22).

By 1870 her father, a Carlist, decided that the family should leave Spain for political reasons. They spent the next three years travelling in France, England and Italy, which provided Pardo Bazán with the time and opportunity to read widely, teach herself English, study philosophy, theology and natural sciences and to delve into German philosophy, particularly Krausism (Clèmessy 1: 16; 
Hemingway 163). She described those years as a wonderful journey during which her desire to write was renewed ("Apuntes" 38). She then added, somewhat wistfully:

Apenas pueden los hombres formarse idea de lo difícil que es para una mujer adquirir cultura autodidáctica y llenar los claros de su educación. Los varones, desde que pueden andar y hablar, concurren á las escuelas de instrucción primaria; luego al Instituto, á la Academia, á la Universidad, sin darse punto de reposo, engranando los estudios. ... Todas ventajas; y para la mujer, obstáculos todos. (“Apuntes” 38)

The early years of Pardo Bazán's marriage appeared happy, enveloped in the social whirl of Madrid enveloping her, leaving no time for literary pursuits, apart from some poems which were published to an acclaim that surprised her (“Apuntes" 26). Three children were born after the couple returned to Spain: Jaime (1876), Blanca (1879) and Carmen (1881). In 1876 her writing career began in earnest with an essay on the Benedictine monk Benito Jerónimo Feijóo (16761764), for which, (somewhat controversially), she won a prize, articles on heat, light and electricity, and analyses of Dante, Milton and Darwin (Clèmessy 1: 20; Hemingway 163).

Pardo Bazán by this time was familiar with the contemporary literature of much of Europe, except, she realised, that of her own Spanish contemporaries. She started reading Juan Valera (1824-1905) and Pedro de Alarcón (1833-91), and from that point, she said, she "needed no further guidance" (“Apuntes” 39). Her reading inspired her to try fiction writing for herself-an activity which appeared 
to her, at that point, to involve little more than describing familiar customs and places, and creating characters by studying the people around her (“Apuntes” 34). Her first novel, Pascual López, Autobiografía de un estudiante de medicina (1879), described by Hemingway as "a relatively light-weight piece”, was accepted for publication (163). During the next two years Pardo Bazán spent time considering various European literary styles, and reached the conclusion that her preference was for "our own national Realism” (“Apuntes” 6o).7

Her preference for Spanish Realism notwithstanding, Pardo Bazán was also attracted to French Naturalism, ${ }^{8}$ particularly Zola's writing, and the "echoes of French Naturalism" which appeared in in the prologue of her second novel, Un viaje de novios (1881) were quite deliberate (“Apuntes" 59). Rutherford comments, however, that in this prologue Pardo Bazán's naturalistic writing "ill assorts with the rest" and has been "inserted with painful deliberation" (289). Pardo Bazán continued to ponder this approach to novelistic writing in a series of essays, published weekly in La Época during 1882, which would eventually form $L a$ cuestión palpitante. Her stated intention in writing these was to "decir algo en forma clara y amena sobre el realismo y naturalismo” (“Apuntes” 64). One of her

\footnotetext{
7 Realism appeared in Spanish novels in the second half of the nineteenth century as the industrialisation of the country gave rise to the middle class, who provided it with its principal subject matter, its public and its literary exponents. Realism described contemporary social reality, depicting experience, activities and emotions objectively, without apparent authorial comment. This raised problems in conservative, Catholic Spain as activities and emotions regarded as sinful feature in the texts, without condemnation, apparently shamelessly promoting immorality and condoning evil. This caused some problems for Realist novelists such as Pardo Bazán and José María de Pereda (1833-1906) who held traditional moral values (Rutherford 27174).

${ }^{8}$ Naturalism began with the French novelist Émile Zola (1940-1902) in the 1880s. The naturalist novelist functioned as an impartial scientist, observing nature, rejecting both supernatural explanations of the physical world and absolute standards of free will and morality. Nature and human experience were viewed as deterministic and mechanical processes, with empirical observation being preferred to imagination (Lehan 529).
} 
arguments was that these "new" literary movements of Realism and Naturalism in fact had their origins in Spanish literature, in works such as Fernando de Rojas's La Celestina (1499) and Miguel de Cervantes's Don Quijote (1605, 1615) (Cuestión 181).

While endorsing Zola in many respects, there were some aspects of Zola's thinking that Pardo Bazán felt compelled to challenge. His stance was one of a rigid deterministic philosophy while, as a self-described “católica apostólica romana”, Pardo Bazán took a different stance (Rutherford 285; Cuestión 352). She was happy to accept the laws of nature, for example, "la caída de la piedra", but she expressed doubts about the inexact sciences such as psychology, commenting that "lo psíquico es irreductible a lo físico" (Cuestión 148).

Inés Alberdi observes that "la polémica acompañó a Pardo Bazán a lo largo de toda su vida", beginning in 1883 with the publication of La cuestión palpitante (55). While Spanish male authors Benito Pérez Galdós (1843-1920), José Ortega Munilla (1856-1922) and Narcís Oller (1846-1930) had already introduced this style of writing into their novels without public comment, the Spanish reading public saw it as shocking when a respectable married woman dared to use the same naturalistic style (Clèmessy 1: 99). Because of this, La cuestión palpitante received a mixed reception among the Spanish reading public. Despite the fact that the noted author Leopoldo Alas (Clarín) (1852-1901) had written the prologue to the book and that the book itself, in which Pardo Bazán describes naturalism and strongly criticises some of its aspects, had been previously published in the newspaper La Época, La cuestión palpitante was alleged by many to be scandalous, indecent, pornographic and godless (Alberdi 57). Others, however, 
were more accepting. Among them was Leopoldo García Ramón (1876-1958) who thought that "Pardo Bazán debe tratar esos asuntos aunque, para los imbéciles, deje de parecer dama española, pues ante que dama es artista. ... Es más hombre que mujer, intelectualmente hablando, y como tal debe portarse" (Tolliver Cigar 24). Unsurprisingly, the notoriety of both the content and, by this time, Pardo Bazán herself led to a huge demand for not only copies of the book but also for Spanish translations of French naturalist novels (Alberdi 56-57; Clèmessy 1: 99).

The controversy that accompanied the reception of La cuestión palpitante, however, was too much for Pardo Bazán’s husband. Quiroga, horrified at the attention, notoriety and criticism that his wife was receiving, asked her to stop writing. She refused and they separated-apparently amicably—in 1884, with Quiroga returning to Galicia and Pardo Bazán remaining in Madrid with the children and her parents. The practical support that her mother was able to provide with child-rearing and household duties enabled Pardo Bazán to concentrate on her literary career. When Quiroga died in 1912 she observed traditional mourning dress and the associated social customs for the next year (Alberdi 24).

Bieder argues that Pardo Bazán considered authorship to be an ungendered activity ("Literary” 19). In a letter to Luis Alfonso following the publication of La cuestión palpitante, Pardo Bazán states that “[d]entro del terreno literario no hay varones ni hembras” (Cuestión 366). Pardo Bazán’s narrative intent and style certainly seemed to differ from the majority of her contemporary women writers, the literata, women such as Sinués whose output was aimed at women, and whose texts reinforced the "Angel in the House" 
construct. And, unlike several of her contemporaries, she was prepared to put her own name to her writing, neither hiding behind a pseudonym, nor relying on her status as a married woman. 9

As Bieder demonstrates, Pardo Bazán followed the currents of male narrative trends, addressing the same broad readership as her male peers, writing within and for a patriarchal society, with fiction built on analogous patriarchal structures and institutions. In much of her fiction she employed male-voiced strategies at both the authorial and narrative levels, which, Bieder asserts, created "no disruption for her readers on the surface" ("Authority" 475).$^{10}$ With her malevoiced narrative and her feminist-leaning content, Pardo Bazán distanced herself from the norms and rhetoric of self-effacement that most other women writers had adopted. On the one hand, she was a living fulfilment of their arguments for equality with men; on the other, she was seen to be breaching the firmly established boundaries of gender activity, thus provoking a polemical response to her work (Bieder "Authority" 475).

\footnotetext{
9 Cecilia Bohl de Faber (1796-1877) published her works under the masculine pseudonym of Fernán Caballero. By contrast Carmen de Burgos (1867-1932) often used the pseudonym "Columbine" (Mandrell 97; Ugarte 6o). Others, for example, Sinués de Marco and Gimeno de Flaquer (1850-1919), who wrote as women, for a female readership, took the opposite path reinforcing their marital state by including their husbands' names in their literary signatures, a style that both affirmed the strictures of female narrative space and confirmed reader expectations (Bieder "Authority" 477-78).

${ }^{10}$ In light of Pardo Bazán's ability to publish her works on an equal platform, and the fact that she directed her writing towards the same readership as her contemporary male writers, the attitude of many of her modern academic critics is surprising. The literary convention of first using an author's full name and then referring to them solely by surname is not often upheld when Pardo Bazán is discussed. Even as they speak of her "authorial authority" they undermine this very authority by using gender or social markers with her name, such as "La Pardo Bazán", "la gallega", "doña Emilia", "la condesa", "la novelista coruñesa" or the overly-familiar (in an academic context) "Emilia" or "our author". Tolliver and Bieder are two critics who have spoken directly against this practice (Tolliver Cigar 178-9 n2o; Bieder "Authority" 478).
} 
Nicola Gilmour also addresses this dilemma which every feminist fin de siècle writer faced. Characterised as "masculine" by critics because of her writing style, Pardo Bazán determined to brush aside the personal insults and endeavoured to remain impervious, "como estatua de mármol”, to this mudslinging and criticism levelled at her by "los malos y los necios" (Pardo Bazán “Educación” 174). However, her private life demonstrated a more conventional femininity—her Catholicism, her nationalist leanings, her fashionable dress, culinary and household skills-all the while continuing to pen the greater part of her fiction under her own name rather than a male pseudonym, using a malevoiced narrative (Gilmour 149-53, 155).

Despite her feminist views, Pardo Bazán “was not generally known for her solidarity with other women writers" (Tolliver "Distinguished" 217). This is exemplified by her response to an invitation by Burgos, another feminist, for support with her 1904 survey on divorce. Pardo Bazán's reply to Burgos consisted only of an implausible excuse followed by polite platitudes, rather than the serious answer that Burgos would have hoped for: "No contesté á usted porque no tengo opinión sobre el divorcio, y por lo tanto no me es posible emitirla. Necesitaría dedicarme á estudiar esa cuestión, y no dispongo de tiempo” (Divorcio 71). Nevertheless, there are instances in her literary output, for example the short story "El indulto", analysed later in this thesis, which demonstrate that she had in fact spent time considering the question.

At times Pardo Bazán appeared to place herself alongside other wellknown female feminist authors, but modern critics have accused her of using these associations for her own ends, her defence of these other women being 
perceived as a "manifestation of her own personal ambition and lack of modesty" (Tolliver "Distinguished" 217-18). An example of this, in 1891, is her invoking of her "excelsa compañera Tula", Gertrudis Gómez Avellaneda (1814-73), in order to further her own ambition to be appointed to a vacant chair in the Real Academia Española (Gómez-Ferrer 30). This led her to her becoming involved in what has been described as the most prolonged public polemic of her career, la cuestión académica (Tolliver "Distinguished" 223).

Thirty years previously Gómez Avellaneda had attempted, unsuccessfully, to be named to the academy. El Correo re-published correspondence surrounding this event in a public attempt to undermine Pardo Bazán's application and the newspaper prophesied the same sorry fate for her. She refuted the newspaper's aspersions in the form of two letters published in El Liberal, addressed to Avellaneda (who had died in 1873), entitled “La cuestión académica: A Gertrudis Gómez Avellaneda (en los campos Elíseos)". In these letters she stated her own case for inclusion to the Academy and pointed out that the same misogynistic ideology that had kept Avellaneda from being accepted in her time appeared to be operating against her now (Gómez-Ferrer 30). However, despite her ongoing efforts, her application was ultimately refused, and her second and third applications for inclusion, in 1892 and 1912 respectively, were similarly unsuccessful.

Arguably, one of Pardo Bazán’s greatest achievements was her singlehanded authorship and production of a monthly literary magazine Nuevo Teatro Crítico. In all, there were thirty issues, each of about a hundred pages, which were self-published between January 1891 and December 1893. Pardo Bazán used 
the magazine to discuss subjects that, in her opinion, had been neglected or glossed over in the press, and to educate "un pueblo joven e inculto" (Varela Jácome 159).

The title, Nuevo Teatro Crítico, was a personal tribute to Feijóo, of whom Pardo Bazán had been a long-time admirer. ${ }^{11}$ Her magazine had a set format, with each issue featuring at least one short story or serialised novella, a critical literary review of a recent book or play, a biography or obituary of a noted author and an essay with a contemporary social or political theme (Varela Jácome 160). Many of these essays were "uncompromising attacks on the gender mores of her time" (Tolliver Cigar 64). In addition, there were travel commentaries, historical essays, religious commentaries, fine art reproductions, or Pardo Bazán’s own contributions to the polemics of the day, such as the "feud" between Valera and Ramón Campoamor (1817-1901). Nuevo Teatro Crítico was a publication which offered "las más diversas materias y asuntos" (Cornide Ferrant 329). And, most importantly, in Benito Varela Jácome’s opinion, the magazine provided Pardo Bazán with a platform to defend her own work, which she did vigorously (16o-61). In addition, she now had the opportunity to publish, without editorial censure, material which crossed the moral boundaries of the time. Short stories, such as "No lo invento" (1891), which deals frankly with necrophilia, and "Cuento primitivo" (1893), in which Pardo Bazán subverts the Biblical story of Adam and Eve by rewriting it from a feminist perspective, are two examples. The magazine served Pardo Bazán well during the three years that it was in existence, with the

\footnotetext{
${ }^{11}$ Feijóo's own magazine was titled Teatro crítico universal o discursos varios en todo género de materias para desengaño de errores comunes.
} 
articles highlighting "la aguda penetración crítica de la autora” (Varela Jácome 164).

Pardo Bazán was relentless in her efforts to improve the educational and cultural levels of Spanish women. In 1892 she created the Biblioteca de la mujer with the aim of publishing in Spanish feminist texts by other authors, encompassing a wide range of themes, including history, literature, religion, sociology and Spanish cuisine. However, as Paredes Núñez explains "no siempre mantuvo este ardor polémico y combativo, y ya en 1913-desengañada de sus ideales-da un brusco cambio a la Biblioteca, donde ahora publica La cocina española" (312). She expressed her frustration at the apparent lack of interest in her crusade in a letter to the Director of La Voz de Galicia:

Cuando yo fundé la Biblioteca de la mujer, era mi objeto difundir en España las obras del alto feminismo extranjero. ... He visto, sin género de duda, que aquí a nadie le preocupan gran cosa tales cuestiones, y a la mujer, aún menos. Cuando, por caso insólito, la mujer española se mezcla en política, pide varias cosas asaz distintas, pero ninguna que directamente, como tal mujer, le interese y convenga. Aquí no hay sufragistas, ni mansas ni bravas. En vista de lo cual, y no gustando de luchar sin ambiente, he resuelto prestar amplitud a la Sección de Economía Doméstica de dicha Biblioteca, y ya que no es útil hablar de derechos y adelantos femeninos, tratar gratamente de cómo se prepara escabeche de perdices y la bizcochada de almendra. (Bravo-Villasante 285) 
About a century later Adrienne Rich was to note that the two choices that women writers have are "to write badly and be patronised or to write well and be attacked" (cited in Showalter 215). This aphorism had certainly been true for Pardo Bazán, who faced on-going opposition and merciless criticism from some of her male contemporaries, with criticism of both her work and her person being published in various magazines and newspapers. Alas, Pereda, and Emilio Bobadilla (Fray Candil) (1862-1921) were three of those heavily involved in personal attacks. They managed to couch their arguments in such a way that it was often impossible for Pardo Bazán to rebut them. An example was Alas's remark about Los pazos de Ulloa: that no woman could produce a good naturalistic narrative, his implication being that either the novel was substandard, or that Pardo Bazán was not a proper woman—or perhaps both. However, when Insolación (1889), which was considered a more "feminine" work, appeared he dismissed it as "trapo" (Tolliver Cigar 23). Pereda compared the “immoral" protagonist of Insolación to Pardo Bazán herself, and Bobadillo referred to Pardo Bazán derisively as "mucho hombre" (Tolliver Cigar 23, 21). Occasionally she did respond directly to the criticisms, notably to the arguments of Alfonso (referred to above); at other times she put it to the criticising men that, as a woman, she was unable to respond (Tolliver "Distinguished" 221).

For the rest of her life Pardo Bazán endured this level of criticism from male peers; it was, Tolliver states, the price that she paid for using the "distancing" form of address rather than the "engaging narrations" of the sentimental novelists (Cigar 34). However, it was her choice of narrative style 
that ultimately won her a place in the canon of Spanish literature; her destiny was to be that of a lone woman speaking within a group of men (Cigar 28). 1916 saw Pardo Bazán appointed catedrática de Lenguas Neolatinas at the Universidad Central, the first Spanish woman ever to be recognised in this manner. However, once more the male bias persisted against her. The students, all male, refused to be taught by a woman. Only one older student attended her classes, and when he stopped coming Pardo Bazán, by then disheartened, resigned (Bravo-Villasante 289-90, 94). She also received other accolades during her life. She was the first female member of the Literature Section of the Athenaeum in Madrid, and in 1906 its first female president and she was also the first female professor at the Escuela de Estudios Superiores (Bravo-Villasante 290).

Pardo Bazán died in Madrid on 12 May 1921, survived by her three children. The eldest, Jaime Quiroga, married Manuela Esteban Collantes (1880-1959) and they had one child, also called Jaime. Tragically, father and son died together, murdered, on 11 August 1936 in Madrid. ${ }^{12}$ Carmen Quiroga remained single and died in 1935 while Blanca Quiroga, also known as María de las Nieves, married José Cavalcanti (1871-1937) and died without descendants in 1970. Pardo Bazán’s family home in Galicia, el Pazo de Meirás, was appropriated by General Franco in 1936 at the start of the Civil War and was lost to the family. Blanca was even denied the right to enter in order to recover her mother's remaining possessions and personal papers. In 1978, on the eve of the Constitutional Referendum, a fire

\footnotetext{
${ }^{12}$ Jaime had previously fathered an illegitimate and unacknowledged son, who had joined the Republican Militia and, taking advantage of the disturbances created by the onset of the Spanish Civil War, he sought out and murdered both his father and legitimate half-brother (Faus 511 n83).
} 
at Meirás destroyed the library and any of Pardo Bazán's papers and books that may have remained there (Alberdi 25-27).

\section{Pardo Bazán's fiction and non-fiction works}

\section{The Essays}

Pardo Bazán was a fearless woman of strong opinions and radical views that were unacceptable to many in her society and, for her, the essay provided an ideal platform to disseminate these views. For almost fifty years, she published hundreds of essays that covered a huge range of topics, beginning with the set of essays on Naturalism in La Época in 1882. With their publication she thrust herself into the public eye and from that point "a constant flow of informed, reasoned often polemical, sometimes impassioned and always timely essays" flowed from her pen covering such diverse topics as travel, hagiography, pedagogy, history, literature, literary criticism and women's rights (Bieder "Literature" 25). They also provided a channel in newspapers and journals both in Spain and abroad, through which Pardo Bazán was able to engage with the critics of her own work.

In fin de siècle Spain the literary essay was considered a "masculine" genre, with educated male writers presenting their ideas to male readers, in a linear and logical manner. For Kathleen M. Glenn and Mercedes Mazquiarán de Rodríguez, one of the main factors that drew authors towards essay writing was the directness of address that enabled the writer to convey their ideas in a forthright but "exposed" manner. In the essay ideas, questions and opinions are presented 
to readers as if the author were speaking directly to them, rather than being expressed indirectly through a fictional character or narrator, for example (6). This direct approach was, however, considered more socially appropriate for a man than for a woman, who was expected to adhere to advice such as that given by José de Manjarrés, in his 1854 Guía de señoritas en el gran mundo: "Si la petulancia elevase la conversación a cierta altura de la ciencia, el silencio sin inquietud deberá ser en una señorita la demonstración más propia de su fina educación" (cited in Scanlon 19). Furthermore, the essay was considered by male writers to be beyond the intellectual and discursive capacities of women (Irizarry 6).

A particularly compelling point for nineteenth-century Spanish women essayists such as Arenal and Pardo Bazán was that this format conferred a degree of gravity to their thoughts, and gave them a public voice, which had previously been denied to them (Glenn and Mazquiarán de Rodríguez 2-3). While Arenal is considered a master of the genre, having published twenty-three volumes of collected essays at her death (Irizarry 6), it is Pardo Bazán who was the most prolific and the most distinguished Spanish woman essayist of the nineteenth century. In them she covered many diverse topics and Bieder asserts that few contemporary Spanish men, let alone women, were able to match the breadth of Pardo Bazán's interests, her reading or her experience (Bieder "Literature" 25, 2829).

Tolliver singles out four of Pardo Bazán’s longer essays which are concerned in some way with feminist issues, and it is these issues which are of particular interest to this thesis (Torn 15). In 1889 Pardo Bazán was invited by 
London's The Fortnightly Review to write "The Women of Spain” in which she gave a frank overview of a woman's subordinate place within Spanish society. The following year it was published in Spain, serialised in four parts, with some amendments, as "La mujer española". "La cuestión académica” and "La educación del hombre y la de la mujer" followed. These latter essays outline some of her views on the place of women in fin de siècle Spain, including the religious and moral education which women received and on women's education in general (or, more correctly, the lack of it) (Torn 15). Pardo Bazán's views on female education were forthright. She believed that girls should have access to the same education as boys, and that the "watering down" of the educational curriculum offered to girls was a disgrace. Thus she used her essays, particularly "La mujer española" and "La educación del hombre y la de la mujer", to disseminate her views. In the former she states plainly that Spanish men appear to prefer: una mujer que sin ambicionar la instrucción fundamental y nutritiva, tenga un baño, barniz o apariencia que la haga "presentable". ... Este sistema educativo donde predominan las medias tintas, y donde se evita como un sacrilegio el ahondar y el consolidar, da el resulto inevitable, limita la mujer ... manteniéndola en perpetua infancia. (Gómez-Ferrer 102)

Walter T. Pattison makes the observation that Pardo Bazán felt that she would be satisfied only if all Spanish women were educated and free to enter all professions (110).

In "Sobre los derechos de la mujer" Pardo Bazán asserted that as far as reclaiming women's rights to gender equality was concerned, there was no 
obstacle that could not be overcome, but the progress was slow. She likened this process to an alpinist laboriously cutting footholds in a rock, looking eagerly towards the summit (Gómez-Ferrer 259). One of the first footholds that Pardo Bazán cut for herself was in 1883 with the publication of "El indulto", and the manner in which she defended her right to speak as she saw fit on the controversial topics raised by this narrative And, from that point on, as Pattison observes, "to the day of her death she kept on urging the reforms she knew would not occur in her time" (110).

\section{The Short Stories}

Pardo Bazán's narrative talents were equally suited to the concise form of the short story, and the density and terseness of her writing, as well as the breadth of themes and her diverse styles were extraordinary (Rutherford 308). Pardo Bazán wrote a remarkable number of short stories; almost 600 have been catalogued by various critics and many have been known to be lost, particularly those published in the Americas (Paredes Núñez 42). Tolliver asserts that, among Spanish writers, only Alas wrote with comparable stylistic skill and diversity, but his production was limited to about sixty short stories (Torn xvii, xviii).

I will argue that, in common with Pardo Bazán's essays (and her novels), her short stories introduce "social questions of immediate concern to her contemporaries" (Bieder "Authority" 473). However, in common with her essaysbut unlike the novels-as I will discuss shortly, in many of the short stories the authority of Spanish patriarchal society is questioned and challenged, rather than reaffirmed. 
The first of Pardo Bazán's short stories, "Un matrimonio del siglo XIX" (1866) was written when she was fifteen, and the last, "El árbol rosa" (1921) was published posthumously in a special edition of the journal Raza Española, which was dedicated to her. The majority of the stories, however, were written between 1890 and 1920. Tolliver comments that, because of the sheer number of her short stories, "there is little critics can do, and little indeed that they have done, but to classify them" (Torn 18-19, n177). Indeed, Juan Paredes Núñez has devoted thirtyfour pages to his various classifications of Pardo Bazán's short stories—by collections (of which there are twenty, compiled by Pardo Bazán herself), alphabetically, by title, chronologically and by publication details (4: 427-61).

Pardo Bazán, together with many other short fiction writers, took full advantage of the literary supplements included in numerous newspapers and journals, which supplied an "appreciative audience" for the short story authors. These publications proliferated in late nineteenth-century Spain, with 1,347 periodicals in print by 1900 (Viñao Frago cited in McKenna 22-23).

Along with other later writers, Pardo Bazán drew models and inspiration from earlier Romantic short stories which relied on popular sources such as folktales, anecdotes and fables, translating "what we know ... into telling" (Charnon Deutsch Nineteenth 19-20). This style, exemplified by the cuento costumbrista, combined a manners narrative with local colour to communicate the author's vision of Spain and its mores. The emphasis was on exposition and commentary rather than plot, with stock characters that were, at times, implausible. 
McKenna notes that in the late nineteenth-century there was a structural change, that of temporal reduction, in the short story. She argues that where the stories of the Romantics and their predecessors spanned the character's life, both before and after the focus of the story, later stories present an interesting and decisive moment, with neither a "before" nor an "after", digressions or secondary characters (20). The Realist and Naturalist authors of this period, such as Valera, Alarcón, Galdós, Alas and Pardo Bazán sometimes retained the literary techniques of the costumbristas, but they rejected their ideology, often preferring a sociological approach, probing beneath the surface of their characters and their circumstances. The works of the late nineteenth century, and Pardo Bazán's work in particular, according to Kirkpatrick, showed a growing interest in characters who were outside a recognisable moral code, causing the actions of these characters to be more open to the reader's interpretation (Románticas 295).

Pardo Bazán's efforts in the genre of the short story have been widely critically acclaimed. Paredes Núñez argues that her great achievement was to bring psychological conflict into the realm of the short story (Charnon-Deutsch Nineteenth $16 \mathrm{n} 8$ ). Pattison takes the praise a step further, stating that it was Pardo Bazán who acclimated the genre and made it a significant part of the Spanish literary scene (92).

Charnon-Deutsch commends Pardo Bazán, in particular, as a writer able to create characters as separate from, or at odds with, her primary focus for a particular narrative. She adds that this is a technique which engages the reader in deeper motivational analysis (Nineteenth 165). "No lo invento" illustrates this point well: the story features a necrophiliac grave-digger as the protagonist, a 
man whose actions, although he can give his own rationale to the court for his behaviour, are well beyond the moral boundaries of the time (or any civilised time, for that matter). But also clearly transmitted in this narrative is Pardo Bazán's condemnation of the then-prevalent ideal of female sexual passivity. As well as characters who are teetering on the edge of society or morality, Pardo Bazán also created characters who are representative of people everywhere, "obsessed with individual problems of loneliness, anxiety, triumph and despair" (Charnon-Deutsch Nineteenth 166).'

\section{The Novels}

Although Pardo Bazán published nineteen novels, ${ }^{13}$ the naturalistic works Los pazos de Ulloa (1886) and La madre naturaleza (1887) are, arguably, those best known. Janet Pérez noted in 1992 that these two texts alone had absorbed almost $80 \%$ of the critical attention dedicated to the author ("Winners" 347 ). However, Pardo Bazán's narrative style was constantly changing and evolving, with Rutherford commenting that this was simply her response to the changes in literary fashions (308). Hemingway observes that her later novellas, Insolación (1889) and Morriña (1889), and the novels Doña Milagros (1891) and Memorias de un solterón (1894), for example, deal more with individuals' inner conflicts and self-deception than external reality, while her last three novels, La quimera (1905), La sirena negra (1908) and Dulce dueño (1911) follow the style of modernismo and explore the psychology of religious experience.

\footnotetext{
${ }^{13}$ A complete chronological list of Pardo Bazán's novels, novellas and important poetic, critical and general works that were published in book form is provided in Hemingway (pp. 169-70).
} 
Rutherford views Pardo Bazán as a realist writer who created characters representative of different social groups and classes. He considers that Una cristiana and La prueba (both 1890), La quimera and La sirena negra have all achieved a "remarkable depth of psychological portrayal", featuring "exceptional people with unusual personal problems" (308). Bieder makes the comment, however, that Pardo Bazán's novels reinforced the existing social structures surrounding her female characters. She acknowledges that within the texts there are “social questions of immediate concern to [Pardo Bazán's] contemporaries” but her conclusion is that the authority of the Spanish patriarchal society has been reaffirmed in Pardo Bazán's novels, rather than challenged ("Authority” 473).

\section{Writing for the Readership}

Bieder's statement above may well be true in relation to Pardo Bazán’s novels. However, in this thesis I assert that this is not the case with many of her short stories. I have selected twelve stories, (selected from over thirty similarly themed stories), to show that in this shorter genre Pardo Bazán has produced numerous instances of overt or subversive challenges to the Spanish patriarchy. I am concerned in particular with the way that Pardo Bazán represented in her stories the reality of contemporary life for many of the women of her time, very often exposing the gender-based injustices that were so anathema to her. "She was not a lighthouse, but a mirror", according to Ronald Hilton, with her output constituting a historical document of her era, demonstrating "how an eminent Spaniard reacted to the problems besetting her country" (346-47). Pardo Bazán's 
concern with the lack of basic freedoms and rights for women in the patriarchal society of fin de siècle Spain has already been briefly discussed, and I will argue that each of the stories in the chapters which follow advocate implicitly for the social change that would grant Spanish women a degree of personal agency within their society.

As Pardo Bazán initially published the majority of her cuentos in magazines, such as Blanco y Negro, El Imparcial, El Liberal, La España Moderna and Sudexprés, which had a mainly male readership, her implicit arguments were being made directly to the people who were able to implement change in their society. She was keenly aware that her implied readers fell into two groups. First were the men who read these magazines and the literary columns in the newspapers and second, the few educated women, who read the same magazines. Articles on politics, both local and international, such as the Cuban crisis of the 1890 or the Chilean civil war in 1891, and diversions-for example, the mathematical puzzle competitions-were the chief reason for the publications' popularity. Such content was deliberately designed to appeal to the male reader as this material was considered to be beyond both the interests and comprehension of women. The literature section, however, and the short stories in particular, were more than likely to be read by men simply in passing. Some magazines, however, such as Blanco y Negro, made "special appeals" to women, with recipes and articles on fashion or the socialites of the day, in an effort to draw in a feminine readership (Charnon-Deutsch "Media" 192-94).

As has already been stated, Pardo Bazán's writing style was crafted to appeal to the male reader, with characters who often, at first glance, appeared to 
conform to the social mores of the day, but like so many of the earlier English women writers such as Jane Austen (1775-1817), Mary Shelley (1797-1857) and Emily Bronte (1818-48), she was also able, (within her narratives), to include deeper, less obvious and less socially acceptable levels of meaning (Gilbert and Gubar 73). By writing in this way her texts could be read at different levels by different readers. This approach was effective for a feminist-leaning woman writer as she endeavoured to produce a narrative acceptable to the majority of her readership, while at the same time critically exposing the lack of autonomy afforded to, in Pardo Bazán’s words, “más de la mitad del género humano” (Gilbert and Gubar 76; Gómez-Ferrer 258).

\section{Two Voices: Two Worldviews}

Pardo Bazán was only too keenly aware that her readership was predominantly male with a worldview that was almost invariably patriarchal. These men expected an authoritarian male voice in their literature and Pardo Bazán's use of this expected male voice in the majority of her short stories provided a point of identification or a point of entry to the stories for these male readers who may have been unable or unwilling to process the undertones and subtleties of any female-voiced framed subtexts directly (Thomas 83). There were, in fact, only a few short stories among the 600 or so that Pardo Bazán wrote that use an explicitly feminine voice and they are always framed by another narrative voice (Tolliver Cigar 90). Two of these are analysed in this thesis- "Champagne" and "El encaje roto" and the framing will be discussed in greater detail as the stories are examined. However, there are many Pardo Bazán stories with a male-voiced 
framing narrative, introducing the protagonist's tale via a voice other than the protagonist's own, resulting in multiple narrative levels within the story. As Charnon-Deutsch states, "no story is ever independent of the techniques that relate it" (Nineteenth 15). Thus a critical analysis of the way in which Pardo Bazán uses this "double narrative" technique in four of the stories will provide some insight into the way that she was able to speak effectively to her different groups of readers.

Susan Lanser's “Toward a Feminist Narratology” examines the implications of narrative framing devices that permit two narrative voices to express different ideologies within the same text. Her particular interest is their use in feminist narratives where one of the voices, usually a powerful male voice, may be direct, strong in both word and tone, and rational or unfeeling. This she calls the "public" voice. It contrasts with the other voice, that of a woman which represents a "discourse of the powerless". This second voice, the "private" voice, may be polite, self-effacing, emotional, gossipy or uncertain. Lanser argues that narratives constructed in this way create both a surface text and a subtext. This subtext may contain an entirely different "message" and be read in an entirely different way from the surface text and, in addition, it may even be written to a different addressee ("Feminist" 348-49). Gerald Prince describes this second voice as providing "a narrative within a narrative" (25).

Walter also discusses such framing devices in her book From the Outside Looking in: Narrative Frames and Narrative Spaces in the Short Stories of Emilia Pardo Bazán. She uses the term “embedding narrator" for Lanser's public voice, normally the stronger one, which provides a setting, or frame, for the main, or 
embedded narrator. Many of Pardo Bazán's short stories use this technique, and as in "Champagne" and "El encaje roto", she occasionally used a feminine embedded narrator which enabled the female to speak using her own voice, rather than having her thoughts "filtered" by an omniscient third-person narrator.

The two narrators in these texts have different levels of discursive authority. The embedding (Walter) or public (Lanser) narrator has no prior existence in the fictional world. They create their own voice, and their role is to address the reader in order to bring this fictional world into existence, thus performing a public act. The embedded (Walter), or private (Lanser) narrator, is a normally a character in the text, bound to the fictional world, and dependent upon it to speak. When they do speak it can only be to others inside the fictional context (Act 138).

The embedding narrator will often become the narratee who acts as an internal audience for the central story about to unfold in the embedded narrative. As the embedded narrator speaks, the embedding narrator is able to participate in the narrative. Each brings their own ideology to bear and it is these interactions, in particular, that contribute to the reader's interpretation of the tale. Pardo Bazán frequently uses this device to introduce a veiled critique involving socially-imposed gender inequities, as we shall see in "Champagne", "Sor Aparición", "Feminista" and "El encaje roto". The outcome is not always straightforward either, leaving the reader to draw their own conclusions (Walter Outside 22, 39). However, Walter argues that the framing devices themselves 
were an attempt by Pardo Bazán to control the readers' interpretations of her stories, a point which will be noted in later chapters (“Tales” 11).

The following chapters will discuss selected individual stories which will reveal the complex, and often tortured, private lives of many of the female characters. Pardo Bazán was an author who knew her country and her own society well and, having had a broad education, she was also familiar with most of European culture and society. With a sharp eye for the minutiae of daily life, she used fleeting incidents, coincidences, even a wayward glance, to construct these tales. The public and private tragedies of women's infidelities, decisions, delusions and mistakes are woven into the narratives that, in the majority of cases, prove to be more complex that an initial reading may suggest. 


\section{Chapter 3: Alone and Destitute}

"All happy families resemble one another; each unhappy family is unhappy in its own way." -Leo Tolstoy, Anna Karenina

Throughout her life Pardo Bazán never passed up an opportunity to use her writing in order to bring her social views and her values to the forefront and defend them (Alberdi 113). The twelve stories featured in the next three chapters will reveal this very clearly and, in each, one or more of Pardo Bazán's feminist views will be identified and discussed. This chapter will examine four stories which consider some of the issues facing women less fortunate than Pardo Bazán herself. With her comfortable upbringing, Pardo Bazán would not have personally identified with these protagonists-poverty-stricken countrywomen and a woman who had, previously, been considered by society as a middle-class angel del hogar, and whose circumstances had suddenly changed. Despite having been comfortably off, when her spouse died she suddenly found herself alone and destitute, without a home, but still with the responsibility of protecting and caring for her children (Pattison 96). Another, more through naivety than design, was abandoned by her husband on her wedding night and ultimately became a prostitute. However, as we shall see, Pardo Bazán treated the situations of these unfortunate women sympathetically.

Pardo Bazán, in her essay "La educación del hombre y de la mujer”, expounded at length on situations such as these: “[E]l eje de la vida femenina para los que así piensan ... no es la dignidad y felicidad propia, sino la ajena del esposo e hijos, y si no hay hijos ni esposo, la del padre o del hermano y cuando éstos faltaren, 
la de la entidad abstracta género masculino" (Gómez-Ferrer 152). Spanish middleclass women were supported by their husbands and not expected to work outside the home. As Pardo Bazán noted "[t]he distinguishing mark of a lady is to do nothing at all" and she adds that even if they wish to work, or need to work there are few vocations open to middle-class women ("Women" 893). If a woman with little education and no marketable skills is forced to support herself and her children, her life can be bleak.

\section{"El indulto"}

Pardo Bazán wrote only about four short stories before 1883. However that year she produced seven, among them, "El indulto" (Paredes Núñez 4: 444). ${ }^{14}$ There was a reason for her tentative beginnings with the genre, according to Mario Santana. Referring to Constantine Cabal's El libro de cómo se hacen todas las cosas (1919), he explains that Pardo Bazán had been discouraged by negative comments from her father about her earlier efforts, but finally "un impulso interior la hizo coger la pluma nuevamente para emborronar dos o tres [cuentos]. Uno de ellos, Indulto, se hizo célebre" (250). "El indulto" first appeared in La Revista Ibérica 1 (1883), (the same year in which she published La cuestión palpitante) and it was later re-published in three separate collections_La dama joven (1885), Cuentos escogidos (1891) and Cuentos de Marineda (1892).

\footnotetext{
${ }^{14}$ All references to the stories in this thesis are taken from Cuentos completos, edited by Paredes Núñez. Subsequent references will be by volume and page numbers only.
} 
In the Prologue to La dama joven Pardo Bazán relates how reaction to the publication of "El indulto" in 1883 was almost instantaneous, with people "afirmando que tenía mucha miga y planteaba toda especie de problemas sociales, morales y jurídicos, y ponía en tela de jucio no sólo el derecho de indulto, sino la indisolubilidad de matrimonio" (Villanueva and González Herrán 7: 7). She agreed that it was a story of some substance, that dealt with, perhaps, half a dozen thorny social problems, but not, she swore, somewhat disingenuously, intentionally. She stated it was a "sucedido que me contaron en Marineda y yo apunté sin quitar una tilde" (7). However, as a writer she felt obliged not to remove anything that she considered important from her work, even after a backlash of negative public opinion (7). Janet Pérez, in "Subversion of Victorian Values and Idea Types”, comments that the origin of this story is ultimately irrelevant, whether it was based on fact, as Pardo Bazán claimed, or not. It was a story, Pérez asserts, which Pardo Bazán chose to retell and "the rhetoric of the retelling is necessarily her own". As will be seen, despite her disavowal, it is a powerful "indictment of the disempowerment of women and their victimisation by spousal abuse" (38).

The narrative of "El indulto" begins in medias res but, as with so many of Pardo Bazán's works, the reader is rapidly informed about preceding events. The narrator is extradiegetic and gender neutral; there is little narratorial intervention in the text, leaving the events to speak for themselves.

Antonia, the protagonist, was married to a butcher's assistant, and they had lived comfortably, together with her mother who had been astute, hard-working and thrifty and, as a result, well off. However, her mother had been brutally murdered and her savings taken, savings that had been coveted by her son-in-law who wished 
to buy his own butchery. Although it appeared obvious to everyone in her community that the woman's son-in-law had murdered her, in court Antonia's oral testimony was disregarded and her husband and his friends contrived a false alibi enabling him to avoid the death penalty but he was jailed for twenty years. He boasted publicly and told Antonia privately that he would murder her also. To compound her problems, she was pregnant, with her son being born a few months later.

However, Antonia's community, "las cariñosas vecinas”, had helped her and offered advice at the times that she was not able cope (1:122). Gradually, over the next few years, the palpable terror that she felt at the thought of her husband and his threats towards her began to diminish. The law, she reasoned, "[e]sa entidad moral, de la cual se formaba Antonia un concepto misterioso y confuso, era sin duda fuerza terrible, pero protectora, mano de hierro que la sostendría al borde del abismo" (1: 123).

How wrong she was. The king, as a part of his marriage celebrations, granted a number of pardons to prisoners. As Antonia collapsed with fear, it was again "las cariñosas vecinas" who stood with her, persuading her to see a lawyer in order to "saber lo que dispone la ley" (1: 123). Her visit to the lawyer confirmed to her that the law was a truly masculine institution. She was dismayed to learn that "[l]a ley, en vez de protógerla obligaba a la hija de la víctima a vivir bajo el mismo techo, maritalmente, con el asesino” (1: 123). “¡A sí los bribones que las hacen las aguantaran!" is the collective chorus of disbelief that rises from the women who gathered on Antonia's behalf (1: 123). Apparently she could obtain a divorce and then separate, but it would take time, and she would need clear proof of her husband's 
mistreatment of her, which she did not have, as his deliberate threats had been in private, without witnesses. The narrator adds that "los pleitos no se acababan nunca, y peor aún si se acaban, porque los perdía siempre el inocente y el pobre" (1: 124).

The husband was not selected for a pardon. However, the next year, on being told that the Queen was pregnant and, after the child's birth, pardons would be once more be offered, Antonia crumbled again, until she heard the astounding newsthat her husband had died in prison! ${ }^{15}$ Colour rose in her cheeks and she wept for joy, "[e]lla era la indultada" (1: 125). Short-lived joy however, as when she arrived home she realised that the news of the death was simply a rumour as her husband was there waiting for her. He refused to let her run away, demanded a meal, and then insisted that she sleep with him—in the same room and bed in which her mother was murdered. The son's screams woke the neighbours the next morning. The man had run off, the boy told them, because he couldn't wake Antonia. A doctor was called. Antonia was in a coma, apparently uninjured. However, she died some hours later. "A natural death" was the doctor's verdict.

Pardo Bazán has provided an ending which fails to explain the reason for Antonia's death, thus encouraging the reader to re-appraise the story in order to reach a satisfactory conclusion (McKenna 47). McKenna suggests that by examining Antonia's plight and considering the role of women in Spanish society and the biased legal system, the reader may reach the same conclusion as she has, which is that Antonia, "[u]nable to withstand the afflictions imposed on her by an insensitive male

${ }^{15}$ The actual events referred to are the marriage of King Alfonso XII and María Cristina (29 November 1879) and the birth of their daughter María de las Mercedes (11 September 1880). 
establishment succumbs to death, as she submits to her husband, with 'la docilidad fatalista de la esclava”' (47).

However, there may be a more prosaic reason for Antonia's death. Mario Santana notes a textual clue early in the narrative-a reference to Antonia's pallidity being the result of a weak heart (1:122). Could Antonia simply have succumbed to this long-standing affliction, and thus the doctor's verdict was the correct one? The ending to this story is undoubtedly (and deliberately) ambiguous. Nevertheless Santana argues that the mystery of the ending is perhaps not "what killed Antonia?" but rather "how does the reader react to her death?" (256), adding that the reader is forced to take a stand that cannot be directly substantiated by the text itself. He further argues that the obvious reading of the story, as a criticism of the female condition under the patriarchal structures of the time, as a defence of Antonia, is biased. In this tale the narrative empathy lies with Antonia and draws the reader into the unfolding events so that they cannot but help feeling compassion for her. However, in order to interpret and judge Antonia's fate, the reader needs to move consciously beyond the facts presented into the realm of ideology (256-57).

A close examination of the text reveals that it is public opinion that has provided the facts in this story. The text does not record the mother's death, Antonia's comments about her husband greedily eyeing his mother-in-law's savings, the court trial itself, the husband's death threat to Antonia or Antonia's conversation with the matrimonial lawyer. Antonia is the only person who knows the truth about these events to which, apart from the court trial, she is the only witness. Nevertheless, a group of women have aligned themselves with her, appearing to believe her story implicitly. The reader's perspective of events is both from a female 
and quasi-objective viewpoint that is, in reality, based on subjectivity. This raises, for Santana a further question: "Is Antonia telling the only possible truth?" Could she have lied? How reliable is Antonia's oral testimony? (258).

Throughout the story two conflicting worlds are apparent. There is the male world of the Law. It is a world of power, truth, facts, and clear proof, here represented at every level; the king, who has the power to issue pardons for prisoners; the court, which has the power to judge between a man and a woman, and will invariably side with the man; lawyers, who proclaim that women's rights are non-existent; and the husband, who can order his wife to share his bed. In contrast, the female world offers opinions, testimonies and rumours. At the husband's trial these two worlds were thrown into sharp relief. Antonia's testimony and the producing of the butcher's cleaver used to commit the murder was considered "indicio vehenísmo" of the husband's guilt, but that was insufficient proof for the judge; he preferred the "truth" spoken by the husband's drunken friends (1: 122-23). Another tension also apparent in the narrative is that between truth and rumour. The foregoing discussion has aligned truth as belonging to the male sphere and rumour to the female. However, as Santana points out, male truths may also be grounded in rumour, rumour legitimised by the power of the State (26o). He cites the rumour about the supposed death of Antonia's husband: it was reported by the captain's orderly's boss; it was spread by a husband, who told his wife, she shared the news at a shop. It then reached the market and by this time everybody would have known about it (1: 125). The source of the rumour, the captain, and the next two links are all male voices, the last three female. With these few lines, Pardo Bazán has stripped the male voice of its unwavering truthfulness and equated it with the 
"hearsay and innuendo" to which the feminine voice has been linked to. Just as the readers realised that in the narrative the communal feminine voice was based only on the testimony of Antonia, allowing the possibility of unreliability, they now have to form an opinion on the reliability or otherwise of the male voice.

This is a narrative whose resolution is objectively impossible, according to Santana (262). In "El indulto" Pardo Bazán has forced her contemporaneous Spanish readers to contemplate their legal systems. The readers are made fully aware of both of Antonia's claims about her husband's behaviour and of her subsequent treatment by the legal system. The reality and depth of her suffering are evident, and it is left to the readers to form their own individual judgement as to the cause of this.

Pardo Bazán, in different essays, examined the social and legal points on which this narrative touches. In "La vida contemporánea" (1904) she discusses, albeit in a historical context, the suffering that a pardon can cause for a woman, in two strong statements that leave no room for doubt as to her views on this topic: "[L]a libertad del criminal es para el inocente decreto de muerte" (Gómez-Ferrer 279). A little further on she states that "[l]a víctima despertará de su intranquilo sueño evocando todos los sufrimientos pasados, reviviendo la atroz vida y creyendo ver entrar por la puerta a su verdugo. Será, cada mañana el despertar del sentenciado que cree que van a decirle 'Ármate de valor ha llegado la hora'” (Gómez-Ferrer 27980).

Pardo Bazán may have, as she asserted, merely retold a tale recorded in a newspaper report. However, an examination of the text reveals an underlying call for female justice in many areas that is difficult to ignore. Antonia's plight is presented 
as fiction but is, nevertheless, factually representative of the majority of rural Spanish women of that era.

\section{“Champagne"}

"Champagne" is a story which provides veiled social critiques of arranged marriages, the moral double standard and the lack of agency for a penniless, uneducated woman in fin de siècle Spain. It was originally published only in Pardo Bazán's Cuentos de amor and not, as so many of her other short stories were, in the popular journals of the day. Tolliver attributes this to both the subject matter-essentially the backstory of a prostitute-and Pardo Bazán's narratorial technique of using a prostitute as a framed first-person narrator "without commentary", which, at that time, would have been perceived as scandalous, especially for a woman writer (Torn 68). Indeed, as stated earlier, "Champagne” is one of the very few of Pardo Bazán's stories which feature a female narrator relating her own story (Tolliver Cigar 172). She adds that on the rare instances that Pardo Bazán does represent female discourse in the first person the fact of the narrator's female sex plays a crucial part in the narrative dynamics (Torn 68).

An omniscient narrator sets the scene and introduces the first of the two characters, Raimundo Valdés, who becomes the narratee for the second, homodiegetic narrator, the un-named protagonist, who is a prostitute. The story begins in medias res, with a conversation between the protagonist and her client, Valdés, who has just uncorked a bottle of champagne for them to share. Valdés's introduction frames the narrative and encourages the protagonist to tell her story, 
which is the main focus of the narrative; his continuing questions and comments prompt her to reveal the details of her story. Valdés himself, with his very presence in the prostitute's company and his forthright questioning about the possible faults of her husband, provides a veiled critique of the moral double standards that operated within nineteenth-century Spanish society.

His "compañera momentánea" seems, to Valdés, to be sad—a "lujo reservado solamente a las mujeres honradas, dueñas de su espíritu y de su corazón” (1: 293). Women like his companion are without rights, even to their own heart and soul, with her paying clients having the right to expect her joviality, no matter how she may be feeling. The implication is that with his money he feels that he should able to buy momentary power and authority over all aspects of his companion. Valdés appears to be oblivious to the fact that he too, by sharing her company, is outside the traditional strict morality of the Catholic Church and, in effect, a dishonourable man.

However, the prostitute's sudden sadness causes Valdés to be curious, and his questioning of her allows her to relate her story. It transpires that the prostitute was indeed sad, because of the memories that surfaced in her mind when she saw the champagne. While still a child, she said, her mother died, and her father, poor and jobless, with two small children to care for, remarried. His new wife, a wealthy jamona, grew to be jealous of her attractive adolescent step-daughter and was in a hurry to get her out of the way. Although the girl was in love with someone else, a financially advantageous marriage to an older wealthy man was secretly arranged by her parents, the girl's own plans not being a consideration. One day the protagonist was suddenly confronted with this decision, being told: “i[A] casarse! no vale 
replica”. Attempts at protest were met with physical blows from her stepmother and she reluctantly acceded to the arrangement (1: 294).

Still, arranged marriages were common in Spain, where women were "traded" advantageously as far as the parents were concerned, often as in this story without the consent of the girl in question, and in secret. On her wedding day, she appeared unhappy during the ceremony and reception, but became more cheerful after the obligatory glass of champagne for the toasts, and even happier after "tres, cuatro, cinco, quizás media docena...”, having being encouraged to keep drinking by her guests (1: 294).

In the coming hours her life was irrevocably altered "not by the marriage itself—but by her own actions and decisions" (Hoffman “Transformations" 238). The effect of the alcohol made her loquacious and, as she explained at length to her husband while they were travelling to his house after the wedding, she was in love with a lieutenant whom she would have preferred to have married. And, she continued, as a revenge for the foiling of this plan, she intended to beat her husband to death. By now, "más pálido que un muerto", her husband was understandably upset (1: 294). As a married man, with full legal control over his drunk and possibly threatening wife, he pondered the situation suddenly facing him, and then ordered the carriage to turn around and go back to her family home.

Equally understandably, her father and step-mother did not welcome her back and made her life with them intolerable. Meanwhile, the lieutenant had married someone else. Considering her by now, limited options, she took the initiative and decided to “tomar la puerta, ¡qué caramba!” (1: 294). By implication, the poverty of the family, who were "sin un céntimo"- "no podía mantenernos el 
pico"-would have prevented the children, particularly the daughter from obtaining any more than a rudimentary education (1: 293). For her, therefore, options for supporting herself as a single woman would be severely limited and prostitution for her became a necessary choice.

However, the protagonist is not delivering a soliloquy. Raimundo Valdés frequently interrupts her with his own comments and questions; by using this technique Pardo Bazán is able to reinforce her message. When the protagonist explains that "[p]or haberme casado ando como me veo" (1: 293), Valdés assumed that her husband must have behaved badly and, without hesitating, he recites a list of some the ways in which Spanish men, in his experience, mistreated their wives: “¿TT]u marido será algún tramposo, algún perdis? ... ¿te daba mala vida? ¿Tenía líos? ¿Te pegaba?"-an indictment of contemporary Spanish male behaviour. And, as the protagonist describes the haste and secrecy of her wedding, Valdés is mystified as to why this should have upset her: "Hija, por ahora no encuentro mucho de particular en tu historia. Casarse así rabiando y por máquina, es bastante frecuente" (1: 293). Here Valdés again acts as the voice of Spanish society. He reminded her of her husband's obligation to support her, despite her disgrace. She told him she had seen a lawyer, but, in retrospect, was too ashamed of her actions to even ask her husband for money for support (1: 295).

Here we see that in the interaction between the protagonists the text of "Champagne" indeed expressed two different ideological perspectives. Valdés's is the "public voice", direct and rational. For him, arranged marriages are simply a practicality and the equanimity with which he speaks of beatings and extra-marital affairs as not uncommon occurrences represent the patriarchal norm. His is the 
worldview that the Spanish reading public expected and preferred. He does have the grace, however to inform the woman of her marital rights, that her husband should have supported her financially. The prostitute's story, the "private voice", is a "discourse of the powerless" (Lanser "Feminist" 349). It forms the subtext within which Pardo Bazán has subtly expressed several feminist critiques of her society. The injustice, in this case, of an arranged marriage is perceived from the point of view of an unwilling and somewhat bewildered bride and the end result of the lack of employment options for poverty-stricken women on their own is made obvious. The fact that work as a prostitute seems so readily available, together with the fact that Valdés was even with her, highlights the ubiquitous "doble moral" in Spanish society. This woman's worldview is far from that of the reader, but with Valdés framing the story, I argue that Pardo Bazán has been successful in presenting these points to her readers, whereas the prostitute's story on its own would have been unacceptable It may have been her lack of experience that led to the multiple glasses of champagne, but the honesty of her narrative, and her subsequent total abandonment by the men who were legally required to care for her have an impact on the reader. The reader is forced to recognise not only how rapidly the course of a woman's life could change and how dire the position of an uneducated woman was, but also the meagre forgiveness that there was in Spanish society for a woman who "challenged the norms" in any way. The tale of the protagonist is a clear illustration of the lack of agency of a woman in her situation. Without their own legal standing, daughters were handed over to be submissive to their husbands and, unable to obtain meaningful socially-sanctioned employment outside the domestic sphere, if the 
marriage irrevocably failed, as this one undoubtedly had, prostitution appeared to be the only possible option.

As a rule, Pardo Bazán acknowledges the character and behavioural faults of her female protagonists, but even when they are not blameless, she is slow to condemn these women. She argues in her widely disseminated essay "The Women of Spain", that as "nine out of ten actions performed by a woman are done in obedience to ideas which have been suggested to her by man, it would be neither just nor reasonable to hold her entirely responsible" (879). In this one short story, relating a single conversation of, perhaps, twenty minutes duration, Pardo Bazán has presented multiple critiques: of the institution of arranged marriage, the helplessness of the woman who finds herself without the protection and support of her father or a husband, the moral double standard whereby a man's sexual transgression outside matrimony is ignored by society, and the physical and emotional harm that a husband is able to inflict on his wife. And possibly, most shocking of all, is that the profession of prostitution for a woman in that society did in fact have some advantages over matrimony. The protagonist's final request-“Anda, ponme más Champagne... Ahora ya puedo beber lo que quiera”-emphasises her freedom both to now drink as much as she wishes, and to ask a man to serve her that drink (1: 295). However, as McKenna observes, the reader is now aware of just how much this freedom has cost her (Crafting 148). 


\section{"Náufragas"}

The very title of the story conjures up images of survivors of a shipwreck, passengers drifting helplessly in a flimsy lifeboat. One minute they are safe, the next, their very survival is in doubt. And that is exactly the situation in which a mother and her two daughters, the main protagonists of this story, find themselves. They are "náufragas, perdidas en el mar madrileño, anegadas casi, con la vista alzada al cielo, con la sensación de caer al abismo" (1: 141).

The mother, "de familia 'distinguida' de médicos y farmacéuticos, que no son gañanes", had been married to a pharmacist and they had made their home in a small country town. The pharmacist was "sin vicios, tan trabajador, tan de su casa" (1: 141), but he did have one tragic flaw: a compulsion to be "up-to-date" in his pharmacy which, for him, meant having at hand the rarest and most costly modern remedies, remedies which a country doctor would not consider prescribing, or which, for that matter, the patients would never consider buying. These patients were country people, content to use "friegas, flor de malva, sanguijuelas y bizmas" (1: 141).

Somewhat ironically, the pharmacist died of jaundice, a common ailment, from which none of his exotic medicines was able to save him. The subsequent sale of both the business and the family home left just enough money for his wife and daughters, now reduced to poverty, to travel to Madrid to find work.

The mother was very particular about what constituted acceptable employment; she would only be interested in a position that would not compromise their middle-class values. They had received vague offers of assistance from the pharmacist's friends, suggestions of good and proper housekeeping options for the 
mother and older daughter, and free schools for the younger one. However, in Madrid, when pressed for details these friends, now described as conocidos indiferentes, with their own problems to attend to, merely fobbed the trio off, with vague murmurs that "times were hard here", as indeed they were, with Spain still recovering from economic troubles following the events of 1898 . However, behind their backs they were lamenting the misplaced optimism of the mother: " $[\mathrm{V}] \mathrm{Vya}$ usted a colocar a tres hembras que quieren acomodo bueno, amos formales, piñones mondados! Dos lugareñas que no han servido nunca... Muy honradas, sí..., pero con toda honradez ¿qué?, vale más tener gracia, saber desenredarse...” (1: 142).

The narrative opens with a lyrical, romantic description of twilight in Madrid- “el fresa con tonos amatista del crepúsculo envuelve en neblina sonrosada, transparente y ardorosa las perspectivas monumentales. ... La fragancia de las acacias en flor se derrama, sugiriendo ensueños de languidez, de ilusión deliciosa.” (1: 141). There are girls selling cut flowers and some women reach for them, only to be pitied if they cannot afford to buy: "Y esto sucedió a las náufragas..." (1: 141). And with this impersonal phrase the protagonist and her daughters are introduced into the narrative: faceless, nameless, poverty-stricken, and passive, unsophisticated country women. Still in mourning for their husband and father, they are women who have never worked outside their home environment.

As the story develops the reader will realise that this twilight, a half-light, neither day nor night, reflects the situation of the protagonists. Pardo Bazán chose to publish the story in Blanco y Negro, a magazine, with a publication run of 9o,ooo that year, which had a stated policy, suggested by the title, of reflecting the contrasts of contemporaneous Spanish society: "La risa y el llanto ... lo triste y lo alegre, lo 
grave y lo baladí ... todo ese ... será lo que nuestro seminario refleje" (CharnonDeutsch "Media" 193, Fictions 263).

Now, after having have been in Madrid for a month, the family realised that they were without any immediate prospect of work or schooling, surrounded by what appeared to be hordes of well-off people, one of whom, they hoped, would have offered to employ them. They existed day to day in the cheapest boarding house possible and, even there, they were in debt while only a few weeks earlier they were comfortable, solid bourgeois citizens. Without the support of their husband and father, in society's eyes they were nothing. The mother, as the ángel del hogar of her own home, was a part of her provincial bourgeois society, but with the loss of the hogar came the loss of her place in this society and, indeed, her entire identity. Now, adrift in Madrid, they were a trio without direction, without agency, living in the shadows, desperately seeking a return to some semblance of normality.

The vain search for employment did have one brief moment of hope but it only lasted for an instant. A friend of the pharmacist's told them that he knew of work for the older daughter, just across from his business, in a popular beer-hall.... The mother and the oldest girl recoiled, scarcely able to believe the implications of this suggestion. The mother politely refused on the girl's behalf: "Mi niña... no sirve para eso". The girl herself blushed and added "[n]o, no; cualquier cosa; pero eso, no" (1: 143).

However, confrontations over debts with their landlady were ongoing and finally she gave them an ultimatum - pay or leave, as she, too, had her own debts. As they had only enough money for two more weeks they frantically searched for housekeeping work, but to no avail. The mother and daughter looked at each other, 
both having the same thoughts: "Era visto que ser honrado, muy honrado, no vale de nada" (1: 144). It was the father's fault, they said to each other, it was because he managed his business so badly, his fault that they were now adrift, fighting these waves that were closing around them, close to drowning. The next time that they passed the pharmacy, the mother, fearing a rebuff from her daughter, enquired as to whether they should go in and enquire about the beer hall job. "En todas partes se puede ser buena" was the daughter's sad reply, her middle-class dignity and modesty about to be sacrificed, or at least endangered, in order that the family survive (1:144).

The reader has been provided with a glimpse of the slightly backward and simplistic provincial worldview that women have left behind; the herbal cures favoured by the ill, and the protagonist's plan to quickly find work in a well-to-do house where she and her daughters would, perhaps, in time, come to be regarded as family. Tolliver emphasises the reluctance of the protagonist to leave the domestic sphere, the only one that she knows (Cigar 158-6o). This has been contrasted with the "mercantile sophistication of the Madridians", people well aware of the economic crisis, loath to employ anybody out of pity (Cigar 160). In fact, the only kindness shown to these women has come from their landlady, who is herself struggling to survive, being only one step ahead of her own creditors.

Pardo Bazán's readers would identify with the opening paragraphs. She is describing "their" Madrid. They would identify with the insinuation that people from the provinces were unsophisticated, paletos, or lugareños, and out of their depth in the capital, and quite possibly identify with the people who had earlier magnanimously offered the widow help, only to brush her aside when she approached them. Tolliver notes that the voice Pardo Bazán uses here is one allied 
with sophisticated urbanites who are economically comfortable (Cigar 162-63). This voice reappears during the story, reinforcing a comforting bourgeois opinion on the plight of the women. It relates their plans for the future, the ease of finding a job, the congeniality of the employers, the free schools in Madrid. The very neutrality of the voice speaking of the unattainable hopes of the "náufragas" would be perceived as ironic by sophisticated madrileños. The narrative voice, stating blandly, "pero con toda honradez ¿qué?, vale más tener gracia, saber desenredarse...” would resonate with the men who, leaving their wives at home, would spend their evenings in the taverns (1: 142).

Pardo Bazán's message to her readers, however, is not one that would reinforce an urban patriarchal lifestyle. Indeed, it is quite the opposite. It highlights the paucity of opportunities available to women outside the home. The former comfort of the protagonist's life provides a deliberate contrast to the unexpected poverty of her situation in Madrid. The mother would like her youngest daughter to still be in school, and she and her older daughter would have received the usual schooling afforded to middle-class girls. We have seen, in this story, however, that their education counts for nothing in their male-dominated society where even housekeeping positions are difficult to secure (while opportunities for prostitutes are, apparently, easily come by). By publishing this short story in a popular magazine, Pardo Bazán has made a sad indictment on fin de siècle Spanish society. 


\section{"Las medias rojas"}

"Las medias rojas" was first published in Por esos mundos, a magazine which focussed on travel, and was later re-published, a year after Pardo Bazán's death, in Cuentos de la tierra, a collection of forty of her short stories set in Galicia. This collection features recurring motifs: misery, superstition, hunger, violence, envy, brutality, ambition and evil—a somewhat disturbing panoply of actions and emotions, but, in Pardo Bazán's eyes, they reflected the true nature of her province (Villanueva and González Herrán 10: xxx). "Las medias rojas", with its depiction of poverty, despair and violence, fits well in this volume.

Ildara, the chief protagonist, is young, pretty and somewhat vain, forever rearranging her hair, which is styled in a similar way to that of well-to-do women. She is a girl with aspirations above her station. However, her reality is that she lives in the Galician countryside, in near poverty on leased estate-land with her widowed father, el tío Clodio. Her days are spent gathering wood and cooking and housekeeping for her father. However, unbeknown to Clodio, she has planned her "escape" to America, where, she has heard, "el oro rueda por las calles y no hay sino bajarse para cogerlo" (3:196). America is the site of her "sueño de porvenir" (3:196). Others from her community had made this journey and Ildara, who has almost reached the age where she will be legally independent from her father, has begun to make her own arrangements for the voyage. Her father, being emotionally attached to his meagre plot of land, was content to stay in Galicia (3: 196).

Pardo Bazán, in her essay "Women of Spain”, vividly describes the life that would be Ildara's if she remained within her community: "In Galicia women ... with children at the breast may be seen digging in the ground, sowing the maize and 
wheat and cutting the grass for the cattle" (904). She refutes the opinions of the (male) theorists who ignore the plight of Galician and other rural women, piously suggesting that all women should remain in the private sphere by stating " $[t]$ he home of the needy peasant woman, where food and firing are wanting ... is almost always empty. The mistress has been emancipated by a liberator, eternal, merciless, and deaf-Necessity" ("Women" 904).

As a realist story, "Las medias rojas", tells the truth about ordinary life (Furst 3). It is presented, according to convention, with one voice, that of an omniscient narrator which gives the reader both access to the thoughts, feelings and motivation of the protagonists, providing a psychological depth and insight. Free indirect discourse is used to represent the interactions of Ildara and her father.

As the story opens Ildara was wet and dishevelled from scavenging firewood. As she entered the house she tidied her hair—her first priority—-then set the fire and prepared the meagre meal—cabbage, potatoes and half-soaked dried beans, all apparently unacknowledged by her father as he was absorbed in rolling a cigar. As she knelt to check the fire her father, suddenly noticing red cotton stockings under her skirt, enquired “¿Qué novidá es esa?” (3: 195). He assumed that Ildara had purchased them with his money, and was angry. As she stood up to his anger, she made a mistake by fabricating a lie about the source of the money for their purchase, saying that she had sold some eggs. Clodio, however, being an astute man, replied that he knew that was untrue, as it was not the laying season. Yet no answer would have satisfied Clodio. His daughter had obviously had access to money to purchase the stockings, and this money must have come from some illicit dealing with a man. 
Becoming uncontrollably enraged and fearing that his daughter was about to leave him, he hurled Ildara against the wall and beat her.

Pardo Bazán uses the narrator's voice at this point to pause the sequence of events and broaden the narrative by revealing Ildara's thoughts. Her first concern was that her father not maim her face in the way that her cousin Marisola had been maimed by being branded by her mother. Ildara knew that the girls who emigrated had to be "perfect", with good teeth and eyesight. She thought of the boat, her boat, and the middle-man, the gancho, who had given her five pesos as an advance in her contract, the source of the money for the stockings. And all these thoughts swirled through her head as her father continued to beat her. The real-time narrative resumes, describing Ildara's vain efforts to shield her face. Her eye was hit, her nose, her cheeks, her mouth. In a few violent moments her dreams of a future were ruined. As she washed her face after the assault, a tooth fell into her hand and she realised that she had been blinded in one eye-her ship would leave without her.

"Las medias rojas" deals explicitly with the damage that patriarchal power can inflict on women physically, socially and emotionally. Ildara, in her father's eyes, transgressed by spending money, which he may have thought of as rightfully his, behind his back, and he reacted by beating his daughter until she would no longer be attractive to anyone. She would now not leave their home, and for the rest of his life she would be there to do his bidding. Pardo Bazán's story concludes with a belated doctor's visit which only confirmed the extent of her injuries; she was permanently blinded in one eye as the blow to her face had caused a detached retina. Again, this detail shows Pardo Bazán's keen and continuing interest in scientific matters. There is no mention of any censure of or charges against Claudio for harming his 
daughter - the law was firmly on the side of the males, and remained so for the next century. ${ }^{16}$ The reader is left with the impression that injuries such as those of both Ildara and Marisol were not uncommon in rural Galicia.

However, as Ildara made efforts to escape the oppressive authority of her father, there is no indication that she in any way realised that she was simply exchanging the authority of one man, her father, for the patriarchal authority of a chain of other men, beginning with the gancho, who would view her as a commodity once she arrived in America. If Ildara could not, in her day to day life in Galicia, find money for a pair of stockings, then it is extremely doubtful that she was paying ahead for her passage to the Americas (most probably Argentina). She had struck an “acuerdo" with the gancho, possibly binding, and she had already (albeit probably unwittingly) drawn five pesos from him against her future earnings (3: 196). This had, if she thought about it, put her in debt to another set of men before she had ever boarded the boat. I argue that Galician girls in Ildara's position were invariably illiterate and if there had been a written contract for her to make "her mark" in order to receive her money, she would have been unaware of its wording and implications. A girl like Ildara was totally dependent on the integrity of the man that she was dealing with to truthfully convey to the wording and intent of the document. ${ }^{17}$

\footnotetext{
${ }^{16}$ It was only in 2013 that a definitive Spanish law which prohibited violence against women was passed. <www://evaw-global-database.unwomen.org/en/countries/europe/spain/2013/planestrategico-del-cuerpo-nacional-de-policia>.

${ }^{17}$ The word "gancho" adds a disturbing element. Carlos Llorca Baus, states that when it is applied to Spanish emigration, middlemen "hook" attractive girls in Europe with promises of employment in America as servants, teachers, or governesses (Llorca Baus 171; Goldar 228). They were in fact agents who had connections to pimps in the Americas, particularly Buenos Aires, a common destination for Spanish emigrants, described by Goldar as "el mayor mercado de carne humana del mundo" (228) There was a special telegraphic code used by the ganchos to alert the Buenos Aires pimps to the imminent arrival of mercadería, the new women. The pimps then met the ships and selected suitable girls, las candidatas, for their brothels (Goldar 228-35).
} 
This story starkly illustrates the dominance of the male in Spanish society in Spain at this time. Ildara may dream of autonomy but she will never be able to truly exercise her own agency and her one attempt failed miserably. Even when her father dies he ensured that she would never travel "hacia horizontes de holganza y lujo. Los que allá vayan, han de ir ... con sus ojos alumbrando y su dentura completa" (3: 197).

Each of the four stories in this chapter, have emphasised the lack of agency that a woman, particularly one who is destitute, has and, in each, Pardo Bazán has presented a veiled challenge to her society's patriarchal values. In "El indulto" she speaks for women whose voice is ignored in the court, those who suffer marital violence, the practical problems that arise from female illiteracy, and those who have no legal recourse to a dissolution of an obviously dysfunctional marriage. In "Champagne" she challenges parentally-arranged marriages which ignore the daughter's wishes, the moral double standard and the lack of employment opportunities for a poorly-educated woman on her own. This latter point is also at the heart of "Náufragas", while in "Las medias rojas" Pardo Bazán problematises the day to day existence of campesinas, highlighting issues of family violence, female submission, illiteracy and emigration. The next chapter will expand on one of these issues in particular, that of the gendered double standards that were accepted in Pardo Bazán’s Spain. 


\section{Chapter 4: Un monstruoso Jano}

"No haya inmoralidad comparable a la de una moral doble ... monstruoso Jano que por un lado ríe con risa de sátiro y por otro se contrae con hipócrita mueca."

—Emilia Pardo Bazán, "La mujer española"

All her life Pardo Bazán railed against the double standards that prevailed in her society. In her opinion, the same standards of behaviour should be applied to everyone, regardless of gender. As has already been stated the two most obvious areas where behavioural standards differed were in religious observance and in marital fidelity.

The three stories included here all have a religious sub-text. "Los huevos pasados" illustrates in a humorous way the gendered double standard of public piety in Spanish society, while the other two stories, "Sor Aparición" and "La culpable", deal explicitly with the far more pernicious gendered moral double standard which permitted men to be unfaithful to their wives and to treat unmarried women with disrespect, behaviour which was widely accepted, even being sanctioned by the Church. The two stories present to the reader a sombre picture of the destruction that this could cause in women's lives.

"Sor Aparición" and "La culpable", set perhaps half a century apart, ${ }^{18}$ also foreground the influence of public opinion—el qué dirán—on Spanish women's lives. The female protagonists both succumb to the seduction of men with whom they believe themselves to be in love and, as a result, their lives are, in society's view,

\footnotetext{
18 "Sor Aparición" is set between 1825 and 1827 (Tolliver "Sor" 396). "La culpable" appears to be set sometime in the late 1800 s, as in earlier years an overnight train journey would not have been possible.
} 
ruined. The first protagonist, Irene, in "Sor Aparición" is overwhelmed and contrite, but deals with her misfortune in an entirely different and, in some ways, more positive manner than the second protagonist, Elisa, in "La culpable". Elisa, incapacitated by guilt, becomes submissive and remorseful to the point of death as a result of her so-called indiscretion.

The stories both focus on the female protagonist, and allow for more than one reading. If read from the patriarchal perspective of fin de siècle society, it can be argued that the women have each received the punishment that society has decreed for their behaviour. An alternative reading from a feminist perspective will emphasise that, although these women did overstep the norms of their society, their anguish is so vividly portrayed in order to provide a dramatic contrast with the attitudes of the men who instigated and were ultimately responsible for the transgressions in the first place. A third reading, examining the religious subtexts of these two narratives, will reveal two very different attitudes towards religious faith.

As has already been discussed, Spanish society was unforgiving to women who had been discovered to have been alone with a man before marriage, while being totally unconcerned about the man's part in this matter. It was a moral double standard that, like other social inequalities, incensed Pardo Bazán. She was particularly scathing on this topic in her essay "La educación del hombre y de la mujer", asserting that: "[N]o haya inmoralidad comparable a la de una moral doble, y que a la duplicidad es preferible la supresión: y la cuestión sexual ha arrastrado a la humanidad a constituirse una moral doble, monstruoso Jano que por un lado ríe con risa de sátiro y por otro se contrae con hipócrita mueca" (Gómez-Ferrer 157-58). With the crafting of these two stories Pardo Bazán illustrated to her readers the 
extent to which this devious male behaviour had an impact on the lives of often totally naïve women.

\section{"Los huevos pasados"}

“Los huevos pasados", one of Pardo Bazán’s few humorous stories, was published in 1899 in two separate collections. The first, Arco Iris, comprised an eclectic selection of stories, while the stories in the second book, Cuentos sacroprofanos, as its title suggests, all have some connection to a spiritual theme. The narrative differs from others in this thesis, in that the protagonist is male and the focus of the story is almost entirely on this man—his actions and interactions with his family, and his attitude to Catholicism. Women, apart from his two daughters, are outside the text.

Ten years previously, in 1889, Pardo Bazán, in her essay “The Women of Spain", unequivocally expounded her views on the double standard of religious observance ingrained in her society. Spanish men, in her view, had a right "greatly assisted by the law" to choose their spiritual beliefs, to be deist, atheist, sceptic or materialist, while their wives, daughters, sisters and mothers must be "nothing else than Catholics pure and simple". She added that "[w]hilst the women are hearing mass their husbands await them, leaning against the pillars of the porch. Only women assist at religious exercises ... and celebrations. All this is so well known and common that nobody pays any attention to it" (885).

However, Pardo Bazán, as a lifelong Catholic, was not advocating for women to reject their faith, but rather, wished that men shared the faith also: "Heaven knows they need it!" she exclaimed. Her argument is that there is a humiliating 
gender inconsistency at play here. The Spanish man has explicitly forbidden women to reject their faith, while he:

arrange[s] his life on an elastic moral system of his own making. ... This is why no Spaniard ... would consent to see the women of his family abandon the religion in which they were brought up. Men there are who have not confessed for thirty years and yet would be shocked to hear that their wives had failed to carry out the commandment of the Church. (884)

In "Los huevos pasados" Pardo Bazán uses humour to address this inconsistency head-on. A third-person extradiegetic narrator introduces the family of the protagonist, Donato López: bourgeois, respected and respectable, a pillar of society. Pardo Bazán's narrator, however, does not quite have the same faith in the solidity of Spanish society, describing it as being "como torre de hierro en postes de caña” (3: 449). López was a man who upheld societal norms, and his refusal to tolerate "la impiedad en materia religiosa" is given particular mention (3: 449). The religious activities of Sra. López and their daughters Enriqueta and Laurita were exemplary and, “como creían sinceramente, sinceramente reprobaban a los incrédulos" (3: 449). The daughters grew up believing that their faith was the same faith which inspired their father, and that they were indeed following "el impulso de un jefe de familia cristiano"- a man who appeared to take a keen interest in their religious formation $(3: 449)$.

However, one day the daughters' implicit faith in their father's own piety was crushed. López was a demanding man as far as his breakfast was concerned. The breakfast itself was simple enough — two boiled eggs—but the exact length of the 
boiling time was difficult to judge. The last household cook had mastered this timing, but she had been dismissed over a theft, and he had refused to eat the eggs that had been served since then. Enriqueta, a mature and resourceful girl, had thought of a way to help her father. She bought a small spirit stove and placed it on the dining table so that she could cook her father's breakfast for him and, as she started the process, she asked him about the timing of the eggs. "Hay que rezar tres Credos—contestó el padre—y al acabar de rezarlos están los huevos perfectamente pasados" (3: 450).

This may appear to be an unusual request. However, it may have been due to the previous cook's illiteracy, which extended to not being able to interpret a clock face to tell the time. The cook, who would have attended Mass from her childhood, would have learnt the Creed by rote. Enriqueta, unable to concentrate on everything, quite sensibly, and with no reason to doubt her father, asked him to do the praying, while she paid attention to the actual cooking of the eggs but, before he had completed reciting the first line of the creed, Lopez's world crumbled around himhe had forgotten it. His mind went blank; he reddened and started to sweat. The girls both instantly realised what was happening. Enriqueta went pale and dropped the saucepan with the eggs in it, while nine-year old Laurita "soltó la carcajada y gritó: ‘Mamá! ¡Mamá! ¡Ven! ¡Ay qué guasa! ¡Papá no sabe el Credo!” (3: 450).

The revelation of López's ignorance reinforces a feminist perspective. The father has unwittingly given Enriqueta a glimpse of what the future holds for her. Although her own faith may be real, she will come to realise that any expectation that her future husband share her faith is remote. Nothing will now alter the disappointment and disillusionment that her father has been revealed as a hypocrite. 
Laurita, who was present also, in time will recognise the truth of what she has just witnessed, that many men, including their father, are hypocrites, insisting that their wives and daughters be pious, while they themselves have unashamedly abandoned their faith. Enriqueta and Laurita, as women, however, will be expected to unquestioningly retain and live by their Catholic faith throughout their lives. Pardo Bazán has presented this story in a light-hearted way, poking fun at the father, but for many Spanish woman the issue was serious.

\section{"Sor Aparición"}

In the preface to Cuentos de amor, the collection in which "Sor Aparición" was published, Pardo Bazán discusses the real life incidents, or sucedidos, which inspired several of her stories. Some were based on common knowledge and others, she said: “[y]o los vestí y arreglé á mi manera, ... por gusto y capricho (Obras completas 8: 351, 353). Some of these stories had shocked her readers, among them "Sor Aparición”, which was based, according to Pardo Bazán on a "broma infame, dada por uno de nuestros mayores poetas románticos" (355). However, she adds that she does not know what became of the original victim of the so-called "joke", whether she entered a convent as Irene, the fictional protagonist, did or not (354-55).

The encoded Juan Camargo, the fictional poet in this story, would almost certainly have been José de Espronceda (1808-1842), whose well-documented womanising, involving licentiousness of the type described in this story, would not have endeared him to Pardo Bazán, despite his undoubted talent as a poet (1: 296). Paredes Núñez in Cuentos Completos simply states, without any discussion, that Camargo is Espronceda (1: 486 n1). 
Pardo Bazán’s “anti-romanticismo” is evident, Clèmessy argues, in La cuestión palpitante (1: 73). Indeed, a large portion of the fourth chapter of Pardo Bazán's work is concerned with her perception of the genre. She offers particularly scathing comments concerning the excesses and extravagances of the Romantic writers themselves, highlighting their dress and hair styles, their lifestyles and vicissitudes and their heightened emotional states, which at times led to self-destruction (Cuestión 162-165). However, despite her distaste for Romantics and Romanticism, Pardo Bazán does acknowledge that the genre provided the foundation for the development of the Realist and even the Naturalist schools of writing which followed (166). Although Pardo Bazán publicly undermined Romanticism she also used her detailed knowledge of the genre and its followers to her own advantage in her writing, as “Sor Aparición” will illustrate.

"Sor Aparición" is a framed story, with the unnamed embedding narrator glimpsing an elderly nun in the courtyard of a convent. At the end of the story it is revealed that this narrator is, in fact, a woman. ${ }^{19}$ It was the nun's eyes which impressed the narrator: they were fiery, intensely black and passionate-eyes that the narrator, seemingly familiar with Romantic hyperbole, thought "deletaban un pasado borrascoso" (1: 295). A chance encounter with an elderly gentleman at her hostel that evening confirmed these thoughts. By coincidence, a friend of the gentleman's father had participated in the very shameful incident that had led to Irene-for that was her secular name-becoming Sor Aparición, the nun in question. The friend who had been part of the event had passed the story on to the man's

\footnotetext{
19 The use of the word "admirada" in the penultimate sentence of the story is the only indication of the gender of the narrator (Tolliver "Sor" 401). In this story, (as in "Feminista"), Pardo Bazán has inserted a character very like herself, attentive, aware and very ready to listen to an interesting life-story.
} 
father, his father had, in turn, passed it to his son, and now the son, as the embedded narrator, is able to recount, albeit third-hand, the events of Irene's long life to his eager listener.

Irene had been young, innocent and beautiful. While still a teenager, her life changed forever when she caught the lustful eye of a poet, Camargo, who sent her a strange poem expressing his desire for her but also lamenting that if he approached her, his touch would destroy her. Apart from the poem Camargo completely ignored her, and left for Madrid shortly afterwards. However, an obsession with him and the poem took over Irene's life from that point on, causing her to waste away and, in the style of a true Romantic heroine, she fell into a decline. In desperation, her parents took her to Madrid, both for treatment and distraction.

A chance meeting in the street led to Camargo courting Irene and, after six months, they had a chance to be alone together. Undeterred by the implicit warning in Camargo's poem that a true relationship was impossible, Irene was happy to be with him and, on the second occasion that they met alone, she succumbed to his seduction. As she lay in Camargo's arms with her eyes closed, trembling and somewhat confused, Camargo laughed and drew back a curtain to reveal eight or ten of his friends who had been lecherously spying on the entire encounter through a curtain. As they all laughed at her and started clapping, Irene fled from Camargo's house, mortified and in a state of considerable disarray, into the street, where she was stoned by some children. Camargo's friends, it transpired, had teased him for being "slow" in his seduction of Irene and his pride had led him to bet with them that he could conquer her. He had obviously won his bet. However the narrator emphasises the cost of this event for Irene. 
These events had all happened some sixty years before. Irene entered the convent soon after and spent years living as a penitent-fasting, praying and torturing herself and, for the first forty years, weeping constantly. To the male narrator this extended penance indicated that she was indeed guilty of a moral lapse for which she had never forgiven herself. The female narrator, seeing the event from a different perspective however, begged to differ: “¿Piensa usted que Sor Aparición no se acuerda del alma infeliz de Camargo?" suggesting that, perhaps, the penance was being offered for two (1: 298).

Two breaks in the indirect narrative serve to point the reader away from an obvious conclusion and draw them in to keep their interest. In the first, the embedding narrator, who has become the narrate, interrupts, sure that she knows what is coming next: "Irene, se enamoró de Camargo, él la desdeñó, y ella, para olvidar, entró en el claustro...” (1: 296). The comment is met with the amused denial that it has to be much more than that or the story wouldn't be worth telling. In the second, the narrator takes the initiative, telling his listener: "Veo en su cara de usted que cree adivinar el desenlace... Verá usted que no" (1: 297). Walter sees in the first remark an implication that it is common for women to be seduced only to be later abandoned, as happens very often in Romantic novels, and then, unable to withstand their shame and society's judgement on them for what is seen as their moral lapse, discover their only option to be the cloister (Outside 113).

The embedding narrator appears delighted that such an eminent poet as Camargo is featuring in this re-told story. Camargo was, in her opinión, "[el] autor del Arcángel maldito—-tal vez el más genuino representante de la fiebre romántica— nombre que lleva en sus sílabas un eco de arrogancia desdeñosa, de mofador desdén, 
de acerba ironía y de nostalgia desesperada y blasfemadora” (1: 296). ${ }^{20}$ With this sentence, the knowledgeable narrator encapsulates the characteristics of the Promethean Romantic hero, a transgressor of the barriers to desire, a superior and socially alienated individual, one with a self-divided consciousness, fired by neversatisfied desire (Kirkpatrick Románticas 14, 23). This hero is a figure linked to Prometheus and Lucifer, and Pardo Bazán underscores this with the mention of Camargo’s Arcángel maldito (Románticas 14).

The self-absorption of this Promethean figure, according to Tolliver, destroys that which it desires, making a woman desirable only if she remains untouched, as Camargo's poem clearly foreshadows. As the man acts out his sexual aggression towards her, he destroys both her desirability and, it must be added, her position as a respectable woman within Spanish society. This action also shifts the figure of the woman from that of a subject in her own right to that of being merely an object. In the story Irene has become an object of Camargo's vanity and pride, presented as a trophy by Camargo to his gawking friends in order to confirm to them his masculinity (“Sor” 397, 400).

There is never any mention of Camargo's having transgressed societal laws, as Irene had done, although it would be difficult for anyone to find his behaviour acceptable. Nor, indeed, does he show any sign of shame or responsibility for his part in this cruel and crude behaviour towards her. Tolliver argues that the embedded narrator, with his supposition of Irene's guilt, subtly reproduces the stance of the original informant, passing on the story of a foolish woman who allowed herself to

\footnotetext{
${ }^{20}$ Two of Espronceda's well-known works, "El estudiante de Salamanca" and "El diablo mundo", can arguably be said to be referenced here. Espronceda himself was a student in Salamanca and "Arcángel maldito" possesses the same connotations as "El diablo mundo".
} 
be seduced, and who was wholly responsible for her own seduction, thus reinforcing the woman's position as an object exchanged among men and, in this case, offered up for the titillation of the "audience". The original transaction was visual and voyeuristic; the embedded narrator's is verbal. She further argues the fact that the female narrator refutes the idea that sole blame for the sadistic incident rests with Irene and suggests that it is Camargo who still needs forgiveness and thus encourages the reader to consider the responsibility of the man ("Sor" 402). It follows, then, that if Irene is innocent, all her penance is for Camargo's soul. However, sixty years of prayer, fasting and self-torture on Irene's part have not sufficed to save Camargo ("Sor" 403).

The differing worldviews of the narrators are again evident. The male embedded narrator, with his readiness to impart his third-hand account of male licentiousness which would not be worth telling without the sordid details, provides a tale that would be of interest to the typical male reader. However, the embedding narrator obviously saw the responsibility for the seduction differently. I argue that because of the framing technique that Pardo Bazán used this woman was able, on equal terms, to express her views as she questioned whether Camargo, as well as Irene, needed absolution and, the reader is also forced to confront this question. By framing the story in this way Pardo Bazán has been able to control its interpretation in order to provide a veiled feminist viewpoint for her readers.

Tolliver argues that "Sor Aparición" was written with two possible interpretations. The first conforms to the societal mores of the day, being the story of an infatuated single young woman who succumbs to the sexual advances of a man. She is publicly shamed—with even children recognising her sin—and has rightfully 
been undergoing penance for this moral lapse, a penance which, it appears, will continue until she dies. The second interpretation is much more radical. Pardo Bazán herself stated that it is a fact that Espronceda committed a similar shocking misogynistic act, and, by barely disguising him as Camargo, she has exposed to her readership the base nature of "the nation's most revered Romantic poet” (Tolliver “Sor" 403).

However, to onlookers, Irene, with her decades of self-imposed discipline and unflinching penance, has turned her situation into something appearing spiritually admirable. Rather than accepting lifelong disgrace and allowing it to destroy her, as happens to Elisa in "La culpable", Irene has created her own path as an intercessor for both herself and Camargo, and as a martyr.

\section{"La culpable"}

Bravo-Villasante singles out "La culpable" as a story in which "la Pardo es sarcástica con una sociedad mezquina, limitada y severísima para las mujeres, para las supuestas faltas de las mujeres, y en cambio muy abierta y comprensiva para los pecados de los hombres" (201). Despite the obvious feminist undertones that this description implies, "La culpable" is also a story which portrays a realistic and sympathetic priest, which, despite the author's authentic Catholic faith, is not common in Pardo Bazán's stories.

Elisa's well-known, very well-connected and moral family barely tolerated her fiancé Adolfo. The couple had been engaged for five years, but her family always found reasons to delay their marriage as they “creían conocerle y presentían su condición moral" (1: 303). Adolfo, frustrated by this behaviour, carefully planned an 
elopement. Elisa agreed and they went off together, spending 24 scandalous hours together on a train. The police were called, not to arrest Adolfo but rather to detain Elisa and take her to a convent. Two weeks later, by then publicly disgraced, she finally married Adolfo. Her family also considered themselves to be disgraced because of her moral lapse. Her parents even refused to attend the wedding, shunning their daughter from that point on, and telling some people that she had died, rather than admit that she had married "in disgrace". Her sisters were too embarrassed about Elisa's behaviour to leave their house for several months. El qué dirán — what "other people" might say, or even think, an anonymous faceless voice of society's moral standards—-pervades the entire narrative.

Pardo Bazán herself was well aware of the power of el qué dirán; indeed it appears to have been a factor in the failure of her own marriage (Alberdi 23). She was also a woman who, as has been shown, amply demonstrated in her own life that other people's opinions could be ignored, and that it was possible for a woman to break society's rules and survive. However, she was an exception and was only too aware that many other women did not possess either her determination or resources to survive outside society's "mainstream".

Marriage, for Elisa, proved not to be her salvation; rather, it was the beginning of a self-inflicted, downward spiral towards an early death. She endeavoured to be a perfect ángel del hogar but was unhappy from the start. Consumed by her guilt, she was described by the narrator as "una mujer desgraciadísima durante toda su vida conyugal" (1:303). Adolfo, for his part, lived for himself from the moment the honeymoon was over, at times spending days absent from the home. Elisa "lloró en silencio" and lived almost as a recluse, even neglecting to educate her children, or 
make decisions on their behalf (1:304). When she discovered a letter among her husband's clothes that confirmed that he was seeing other women and not attending political meetings as he had claimed, she was devastated. Meanwhile her husband had denied her even the right to manage their household finances, lying to her about the fact that she had received her full inheritance following the death of her father. Indeed, "se hizo cargo de todo y dedicó la mayor parte a sus goces" (1:304). This will come as no surprise to the reader, as the aim of his courtship of Elisa had been to secure "la presa de la acaudalada muchacha" as the narrator states (1: 303). It is arguable as to whether Adolfo had ever truly loved Elisa for herself, while Elisa was smitten with him from the moment they met until she died.

Elisa's married life is succinctly described at the start of the narrative: "[F]ue una mujer desgraciadísima durante toda su vida conyugal y murió, joven aún minada por las penas" (1:303). Her society had condemned her, as the narrator wryly notes: "[Y]a se sabe que Dios es muy bueno; ipero en cambio, los hombres jamás olvidan ciertas cosas, y la mancha de vergüenza allí está sobre la frente hasta la última hora del vivir!" (1: 304). And so it was with Elisa. As she was dying, her one desire was a word of forgiveness from her husband, forgiveness for her sin that day on the train. It took a few seconds for Adolfo to respond to her request, but eventually he gave her a perfunctory kiss, enabling her to die in peace, happy for the first time since her marriage.

McKenna argues that Spanish society itself, the Church, Adolfo, and Elisa's family are all equally responsible for the lovers' "so-called transgression” (89-9o). Although the Church has offered absolution for this transgression, it is Elisa herself who cannot accept it or forgive herself, unable to overcome her belief that she will 
always be guilty (Bieder "Subversion" 145). It is my argument, furthermore, that the priest is the one voice in the narrative that dares to challenge Elisa's attitude of socially-induced, permanent self-guilt. He had heard her, "por centésima vez", accuse herself over that sinful day on the train and this time he implored her to deal with her present-day shortcomings "porque Dios no acostumbra recontar los ya perdonados y absueltos" (1: 304$)$. Sadly, his advice was too late to be effective as, at that moment, Elisa was dying.

Less than ten years previously, Pardo Bazán, in her essay “The Women of Spain", had written that "husbands and all others who hold authority over women, know that the confessor is rather an ally than an enemy" (886). However with this exhortation from the priest in "La culpable", Pardo Bazán has made a strong antipatriarchal (and at the same time Christian) statement. These words have taken the priest beyond his accepted (and acceptable) role of upholding the male norms of society, which included the tacit acceptance of male extra-marital relationships. ${ }^{21}$ Instead he emphasised that God himself had already absolved Elisa for her part in the elopement. The priest delivers a message which, if it had been delivered to Elisa somewhat earlier, and had she heeded it, could have brought her life back to some normality. His message, one of Christian compassion, is a strong rebuke to the faceless el qué dirán of Spanish society.

Adolfo is depicted as a schemer and opportunist, revealed in his meticulous planning and execution of the passionate elopement, which would have necessitated him persuading Elisa to overcome any reservations that she may have had about the

\footnotetext{
${ }^{21}$ The direct yet compassionate words of the un-named priest in this story can be favourably contrasted with the traditional, misogynistic views expressed by Father Incienso in "La novia fiel".
} 
consequences. His extra-marital affairs, his shifting of all the disgrace that the elopement caused on to his wife and his absolute control of her money, although common enough occurrences, were, nevertheless, outside the realm of an ideal marriage. In accordance with the societal norms of the time, however, the story offers not one word of overt condemnation of Adolfo's behaviour.

The hypocrisy of Adolfo's final kiss, Thomas Feeny argues, illustrates Pardo Bazán's contention that man's forgiveness is totally without meaning (12). With this last act in their marriage, Pardo Bazán has given the reader the opportunity to reconsider Elisa's "moral lapse". There were two people involved in the escapade, but only one had imagined, planned and instigated it. The other may have been willing, but was not responsible for its execution. It was a foolhardy thing to do; they must both have known that. For one, the only consequence appeared to be the lack of a society wedding; for the other, it led to a life of remorse and, ultimately, an early death. One tried to make amends; the other lived totally selfishly, indeed, benefitting from his actions, without any fear of consequences. Surely something in Spanish patriarchal society must be fundamentally wrong, the reader is encouraged to think, for Elisa to be convinced that she needs the forgiveness of her husband. Should he not be the one apologising to her for his instigation of the elopement and its consequences?

Again Pardo Bazán has published a story that can be read as one that simply conforms to the accepted patriarchal societal mores of blaming and ostracising both a girl and her family for a moral lapse, despite her efforts to be a model wife. The closure of the story with Elisa's inevitable death conforms to traditional nineteenthcentury narrative closure (McKenna 89). However, given the markedly polarised 
protagonists, who are both extreme in their own way, the hypocrisy of this conventional closure appears evident. McKenna suggests that the reader may choose to "reenter the text for further clarification" and offers an alternative interpretation: that the "guilty" are those who impose hypocritical standards on others, only to violate those same standards whenever they please (89). In addition, McKenna argues, it is a story which challenges the conventional images that (falsely) represent and characterise both men and women (90).

Pardo Bazán has offered no overt condemnation of Adolfo's actions, whether the story is read in a way which conforms to the traditional nineteenth-century patriarchal worldview, or from a wider feminist perspective. Instead, I argue, by depicting Adolfo as such an inflexible, mercenary and manipulative character who has caused Elisa so much mental anguish, the reader is encouraged to form a judgement in favour of Elisa. The reader has been exposed to the inequality and lack of rights to which the fin de siècle woman was subject and invited to support the woman.

The protagonists of these two stories, Irene and Elisa, were both young women who had their futures destroyed by scheming men. Camargo was driven by macho comradeship, his exploits creating a legend which was shamelessly passed from one man to another. Irene, having accepted her downfall, was able to exert her own agency once she had entered the convent. Her life of penance was not the life that she had envisioned for herself, but it was lived on her terms: a life of fasting, prayer, weeping and self-denial, a life that amazed her fellow nuns with its intensity and purpose. Pardo Bazán may have shocked her readers with this tale, but she has 
also drawn, for the perceptive reader, a strong, resolute and intensely spiritual woman.

Elisa, on the other hand, willingly agreed to be courted by Adolfo, who, it is revealed, was driven by greed. However, her acquiescence to his scheming and the public disgrace brought on her by Adolfo's actions caused her to withdraw into herself and relinquish any agency that she had as a married woman. Some degree of self-determination was still in her hands but she could not bring herself to accept it. In these two stories Pardo Bazán underscored the shallowness and cruelty of the masculine moral double standard that permeated her society without overtly saying so and furthermore, in "La culpable", she has promoted an image of Catholicism that is more supportive of women. 


\section{Chapter 5: A Mind of Her Own}

"I won't tell you that the world matters nothing,

or the world's voice, or the voice of society.

They matter a good deal. They matter far too much.

But there are moments when one has to choose between living one's own life, fully, entirely, completely

-or dragging out some false, shallow, degrading existence that the world in its hypocrisy demands.

You have that moment now. Choose!"

-Oscar Wilde, Lady Windermere's Fan

The five stories analysed in this chapter share a common theme, that of women who overtly challenge or more subtly subvert the accepted Spanish fin de siècle behaviour norms of courtship and marriage in order to further their own interests in one way or another. As Pérez argues, most of the protagonists of Pardo Bazán’s courtship and marriage stories are not the "willing victims" that Spanish society demanded, but rather, they resemble the enlightened heroines of English courtship novels, such as those by Austen-although Celina, in "Paracaídas", arguably wishes to go further than any Austen heroine ever would have. The women in these five tales all become protagonists with significant prerogatives of choice and action, which they exercise, or intend to exercise. Their reasons for acting outside traditionally accepted roles are varied, but far from trivial (Pérez "Winners" 349-50).

\section{¡Represalias!}

In the first two stories I analyse the protagonists who unexpectedly find themselves humiliated by their husbands. For Clotilde, in "Feminista", it happened on the first morning of her marriage. For years she patiently heeded the lesson of subservience that her husband had so unfeelingly imparted that morning, but when he became 
enfeebled by illness an opportunity for revenge on him presented itself. Her actions were intended to be private. However, in crowded spa surroundings her secret became widely known. Celina, by contrast, had thought that her marriage was ideal until she was publicly humiliated by her husband's affair with a cabaret singer. An equally public revenge was her planned response: she too would become a cabaret singer, so famous that her husband would be shamed for allowing his wife to behave in such a manner. Both of these women exerted agency for themselves (or planned to) in defiance of the prevailing social mores.

\section{"Feminista"}

Husband and wife, Nicolás Abréu and Clotilde Pedregales, to a casual observer at the Aguasacras spa, appeared to the narrator to be happy, despite Nicolás's very public misogynistic rantings, to anyone who would listen, about the modern-day lack of male authority in the domestic sphere. Clotilde seemed happily resigned to both hearing her ailing husband's views and caring for him. When a spa client, the narrator, unexpectedly met the medical director of the spa on a Madrid street, the Abréus' name surfaced as they conversed.

With this unremarkable introduction Pardo Bazán frames one of her more radical narratives as the spa director reveals Clotilde's behaviour during the couple's stay at the spa, behaviour that was outside the norms of nineteenth-century patriarchal Spain. “Feminista” was published in Pardo Bazán's collection Sud Exprés: Cuentos actuales, stories which were modernist, decadent, and light in tone. The subgroup containing "Feminista" oscillates "entre la leve ironía y el cruel sarcasmo" (Villanueva and González Herrán 8: xix-xx, xxiii). 
The spa patron is the embedding narrator of "Feminista", becoming the narratee for the spa director's tale. Pardo Bazán has left it unclear, from either the context or the language of the narrative, if the embedding narrator is male or female; it is a gender-neutral voice which remains intentionally ambiguous. The story, related by the spa director, falls into two parts. The first begins with an account of the Abréus' marriage, an event which took place without any real courtship as Nicolás chose his wife only because she was pretty and from a good family. Her parents "se la dieron gustosos" because he was a man of money and position (3: 108). Clotilde herself appears to have been voiceless during these arrangements.

On their first morning as a married couple Nicolás demanded that his wife get out of bed and put on his trousers. As Clotilde hesitated, somewhat mystified at this strange request, he snapped at her: “¿Has oído? ... ¡Ahora mismo, hija mía!” (3:108). She pulled his trousers on and then he lectured her, using his trousers as a vivid metaphor to emphasise his authority. He told her sternly that it was the first and last time that she would wear trousers, as he was in charge and he would, henceforth, be obeyed. Clotilde had entered the marriage somewhat naïvely, imagining that a marriage relationship would be based on love. Now disillusioned, she realised it would be based on servitude.

After that morning Clotilde said nothing: “[G]uardó ese silencio absoluto, impenetrable”, while Nicolás, unashamedly, “anduvo jactándose de ello como de una agudeza y un rasgo de carácter que convendría que imitasen todos los varones para cimentar sólidamente los fueros del cabeza de familia..." (3: 108). Bieder observes that many contemporaneous readers, both male and female, outraged by the "feminists" 
of their society, would doubtless have applauded Nicolás's behaviour ("Subversion” $150)$.

The second half of the tale, however, destabilises this image of the "angel wife" completely. The title itself, "Feminista", which provoked a huge outcry, gives some indication that traditional gender boundaries are about to be crossed (Garza Revindicación 50).The spa director, normally “un hombre muy ... discreto", informs his listener about the Abréus' strange behaviour during their last stay at the spa (3: 107), a story that has been repeated to him often during its wide circulation amongst spa guests. It was first reported, he says, perhaps by chambermaids, or possibly the people in the next room-he waves away the question of the exact origin of the story, (and any responsibility on his part not to gossip), adding "en los balnearios no hay nada secreto" (3:107). Nicolás was by then gravely ill and Clotilde had become his full-time nurse, an occupation which she appeared to carry out with the utmost care and diligence, apparently resigned to her fate and modelling "the wifely virtue of abnegation" (Bieder "Subversion" 148). However Clotilde's "public face" was a façade, as each morning, as they arose, she issued her husband with an order “iPonte mis enaguas, querido Nicolás! ¡Ponte aprisa mis enaguas!” “Para que sepas que la llevas ya todo tu vida, mientras yo sea tu enfermerita, ¿entiendes?”, she added, sweetly (3: 109). And each morning her husband would reluctantly comply with her order until Clotilde was ready to help him dress for the day. With the revelation of her actions Clotilde has been re-plotted-from a self-sacrificing wife to, depending on the reader's worldview, either an avenging angel or a quick-thinking feminist (Bieder "Subversion" 142). 
There are two narrative perspectives in this story. The first is the embedding narrator, the spa patron. This narrator sets the scene for the story, introducing the Abréus and their public behaviour at the spa. The second narrative voice is that of the spa director, obviously masculine and authoritative. However, it lacks the forcefulness and male-oriented worldview which characterises many of Pardo Bazán's male narrators. This voice is gossipy (an ironic quality given that the first narrator has previously described this man as "discreet"). It is unsupportive of the male protagonist and at the same time not judgemental of the actions of the female protagonist. If anything, he appears pleased that she has so successfully out-witted her husband (Walter Outside 152-53).

Bieder highlights the symmetry in this narrative, with its structure of reversal. The spa patrons' enjoyment of the husband's comeuppance contrasts with the discomfort that many of them would have felt listening to Nicolás's blustering diatribes about the superiority of men. Bieder asserts that the story illustrates first the male's power to define the limitations of the female and then the newly empowered female reversing this same authority ("Subversion" 150). As the reader begins the story, it would appear to be about Nicolás. It is only as the last couple of paragraphs have been read that it is evident that it is, in fact, about Clotilde.

In "Feminista” Pardo Bazán has depicted a somewhat extreme example of the extent of patriarchal expectations and authority within a marriage relationship, but its very extremity provides a backdrop of humour to the story. The final paragraphs are, in their own way, equally radical. The narrative is designed to provoke a reaction in the reader and offer a challenge to their way of thinking, whatever their views on patriarchal authority may be. The title "Feminista" would resonate with men who 
saw Nicolás upholding traditional values and presumably their view of feminists as meddlers interfering with the fabric of Spanish society. These men would be horrified at Clotilde's actions. Nevertheless, even for this group of readers, Nicolás's hypocrisy and unkindness would be evident. On the other hand, women readers who were trapped in similar marital situations to Clotilde would surely be encouraged. This woman, albeit fictional, saw her opportunity to exert some agency of her own and seized it, leveraging her role as a ministering angel into a position of power and ultimately gaining the upper hand, to a degree that she could never have imagined with the aid of the unasked-for publicity. Bieder cites Thomas Leitch, who has postulated that every short story must mount a challenge to the way its world is first delineated, before it can achieve a sense of resolution or closure, even if the challenge takes the form of an ironic joke (151). The poetic justice in "Feminista" must indeed be considered an ironic joke ("Subversion" 151).

\section{"Paracaídas"}

The injustices of Spain's moral double standard and the gender inequality that fin de siècle Spanish law imposed on a separated woman, who was legally required to remain under the authority of a philandering husband, are the particular social issues highlighted by "Paracaídas”. The story, in Bravo-Villasante’s view, is written from a feminist viewpoint, detailing one woman's plan of revenge against an unfaithful husband (202). I agree that this is perhaps the obvious reading. However, I will argue that a second, equally important, parallel reading of the text reveals a narrative of motherly love and self-sacrifice. 
The story was first published in a bi-weekly Madrid magazine, La Ilustración Española y Americana, which was, according to La Fundación Joaquín Díaz, "sin género de dudas, la publicación más importante de la segunda mitad del siglo XIX español". This magazine, sold throughout the Spanish-speaking world, was a "Museo Universal”, according to its masthead, of "ciencias, artes, literature, industria y conocimientos útiles". ${ }^{22}$ More than eighty of Pardo Bazán's short stories appeared in this publication and other well-known writers including Alarcón, Alas, Campoamor, Unamuno and Zorrilla were also regular contributors to the magazine.

"Paracaídas" is the only story in this selection which was published in $L a$ Ilustración Española y Americana. It is a daring story, detailing the spirited plans of a betrayed bourgeois wife to become a cabaret singer, a plan which, if successful, would be a revenge on her adulterous husband. The narrative clearly challenges the contemporary, cavalier, male attitudes to both the moral double standard and the prevalent gender inequality in marital separations. ${ }^{23}$ These two topics were among the multiple issues on which Pardo Bazán, in her essays, propounded her very strong views and, by publishing this story in such an influential magazine, with world-wide circulation, she was able to disseminate her views far beyond Spain.

In "Paracaídas", Pardo Bazán again uses the technique of reversal, in order to place these gender-based injustices at the forefront of the tale, offering the woman a position of authority and agency (Bieder "Subversion" 153). Celina, the fictional protagonist, represents a new generation of women who are not prepared to simply accept the status quo. The story also arguably reflects the fact that, despite Spain's

\footnotetext{
$22<$ <ww.cervantesvirtual.com/partes/234931/la-ilustracion-espanola-y-americana/99>.

23 The Código Civil dictated that a woman lacked autonomous rights, even after a legal separation $<$ http://noticias.juridicas.com/base_datos/Vacatio/vo-cc.lit4.html>.
} 
lack of organised national feminist movement, the women who were actively promoting feminist ideals, such as Pardo Bazán herself, Arenal, Carmen de Burgos and Rosario de Acuña were, in reality, having some impact on society, and old attitudes were changing.

"Paracaídas"has two protagonists, Celina, and her now widowed mother, la señora de Marialva, who hold differing views. The surface reading of the narrative will reveal Celina as a new-generation progressive woman, una mujer nueva, ${ }^{24}$ who is not afraid to both hold and express her own views about being betrayed, while her mother represents the traditional ideal of the ángel del hogar. The mother models the wifely virtue of unquestioning resignation and passive acceptance when confronted with marital infidelity, personifying the ideal woman, one who has been given "an august guardian, God" by her husband. Should the husband seek "pleasure and distraction abroad", God will then be the One who consoles his wife (Bieder "Women" 884).

An alternative reading of "Paracaídas" places the mother as the protagonist of the story, fulfilling a selfless role. The narrative details her somewhat tragic family life: her husband and three of her six children have died and her two living sons are idle, vicious spendthrifts who only see her when they want money. The narrator comments that motherhood is characterised by "solidaridad con unos cuantos seres para sufrir doblemente lo que ellos sufran” (1: 241). Celina's home, for her mother, was an oasis of peace and rest, and Celina too appeared happy. She married Tomás

\footnotetext{
${ }^{24}$ La mujer nueva was a new, emerging, gender ideal, exemplified by Pardo Bazán herself. The mujeres nuevas challenged the traditional ángel del hogar model by accessing specific areas of public activity such as education, culture, social welfare and new sectors of the labour market (Nash 30-31).
} 
Espaldares "por inclinación, no por codicia de los millones del cosechero, [y] estaba cada día más prendada" (1: 241). Before they were married, the couple had discussed their hopes for their life together and Tómas had promised to be open with Celina, "sin ambages", and never to expose her to ridicule, shame or betrayal (1: 242).

However, by having an affair with a cupletista, he has reneged on this agreement, leaving her both humiliated and angry. She sought solace in her mother, who, unknown to Celina, had also experienced marital betrayal.

However, the reactions of the mother and daughter to marital infidelity are very different. The mother simply accepted the fact, telling Celina: “ $\mathrm{iHija}$ de mi vida, pobre es el consuelo; pero tu caso es tan corriente: Todas, o casi todas las mujeres, hemos..., hemos...! ... [1]as mujeres nacemos para eso: para ser burladas... y perdonar" (1: 242). Celina, however, could not find it in herself to be either accepting or forgiving of Tomás's behaviour-in fact she worked out a plan to take her revenge. As far as she was concerned, her life had been destroyed "iMamá", "mi caso es corriente..., mi alma no lo es!" she cries (1: 242). Celina then explained and justified her plans to her mother. She had trusted Tomás's pre-wedding promises, and asserted that she had the right to take revenge as " $\left.{ }_{i}\right]$ el engaño da derecho al desquite!"(1: 242). However, her mother was appalled when the details of her daughter's "retaliation" were spelled out: "Adopto una profesión festiva. ... Pues cupletista me hago" (1: 242). She imagined herself with an adoring audience applauding her, showering her with presents and baskets of flowers-"como los que Tomás le manda a esa mujer"—and Tomás would read the glowing reviews of her performances every morning in his daily newspaper (1:242). 
The two women were both familiar with Spanish marital law, and for the second time her mother voiced her conservative and traditional views: "Tu marido puede oponerse a que hagas ese género de vida" (1: 242). Celina, though, had her reasoning for thinking otherwise. Tomás had not honoured their pre-nuptial agreement and the law had not prevented her heart being broken. Therefore she viewed her planned revenge as being both just and fair, adding: "Ya sabes que soy mujer que cumple lo que dice ... esa solución, ... era la más justa” (1:242). Celina was persuasive in her argument and her mother recognised her headstrong daughter's point of view. Furthermore, she realised that nothing she could say at that point would alter it and, in order to help Celina she would have to go along with her for the time being. Against the values which she expressed all her life, she said to her daughter: “[C]omo no has de andar por el mundo sola, iré contigo... ¿Me lo permites, Celina?” Celina replied “Sí, vente, madre... ¿Quién sabe si me salvarás?” (1: 243).

The narrative is introduced by a third-person, extradiagetic narrator who reflects on the situations of the protagonists, as well as providing the background to the two women's lives. The opening statement “i[e]s tan vulgar el caso!”, teases the reader from the start, and they are halfway through the story before any explanation of these somewhat enigmatic words is given (1: 241). The second half of the narrative explains "el caso" by means of a lengthy section of free direct discourse whereby the two women, with only occasional narratorial observations, both speak frankly, each expressing their own worldview, one in accordance with the social mores of the day, the other with a more radical mind-set. The mother, who listens far more than she speaks (which is appropriate for an angel), attempts to temper each of her daughter's 
ideas with an "acceptable" reply as to why her daughter should not carry out her radical plan.

The "written warning" early in the story that "algunas veces la realidad presenta inesperadas complicaciones, y no son los finales tan pacíficos y burgueses" (1: 241) suggests that the usual pattern of forgiveness towards the husband on the wife's part and "keeping it in the family" might not be followed in this instance. In fact, Celina has no intention of quietly pardoning her husband or of resuming her previous lifestyle. She has thought through her next move. It is evident that she has been badly treated, that the law has failed her and that her new "career move" may be unwise but, she has ascertained, not illegal. While it is doubtful that she has any real grasp of what will lie ahead for her, risking the safe, if unhappy, middle-class existence that she is accustomed to, she has made up her mind.

Her mother listened to her arguments, and replied as a "good" mother would. But when Celina finished explaining herself, she realised that she must be with her daughter, rather than against her, in order to support and help her. Perhaps, sometime in the future, she would be able to persuade Celina to reconsider her decision, but for the present she must put aside her own life-long reservations about straying from traditional female ideals and support her daughter's views and intended lifestyle. If Celina succeeded, it would bring flowers and wonderful newspaper reviews, but also social disgrace and shame that would exclude her from her bourgeois society. If Celina is about to throw herself headlong into unknown territory her mother will set aside her personal wishes, and indeed her personal values, to accompany her and soften her landing. It is at this point that the reader finally understands the meaning of the story's title "Paracaídas". The mother is 
selflessly surrendering her life to be a metaphorical "parachute" for Celina, delaying and softening her daughter's almost inevitable crash with reality as she leaps into the unknown brazen world of cupletistas.

At the beginning of the story the mother represents the "ideal woman" in a patriarchal society—patient, submissive and forgiving of her husband's marital betrayal, indeed, forgiving of every Spanish male's betrayal. This is indicated in her words, quoted above, that women are born to be deceived in this way, and then to pardon the offender. Celina, however, represents the views of a growing number of women, las mujeres nuevas, who did not simply accept that this was their role and were prepared to challenge the very real injustices that women were expected to endure in Spanish society. The narrative concludes with the women deciding to make this move together, with the mother supporting her daughter's subversive decision. The reader is left with a question: how will the story end for them? Have Celina's arguments convinced the reader that it will end in applause, baskets of flowers and glowing reviews? Or have they adopted the more realistic, and possibly cynical view that Celina's intended actions will end in personal failure and a moral "fall"? Her views may have been valid from a feminist perspective, but they were still unacceptable to mainstream Spanish society. In this respect she is a typical Pardo Bazán female protagonist, who, according to Pérez, refuses to be a mere passive victim—even if her rebellion fails and she is forced to accept a conventional resolution. In deciding to follow her own desires she represents an alternative, ceasing to be an object and becoming a subject in her own right ("Winners" 355).

An interesting comparison can be drawn between this story and "Feminista". Although the marriages of the two couples were contracted on different bases-that 
of Celina and Tomás on mutual affection and that of Clotilde and Nicolás by parental arrangement—both of the wives were humiliated by their respective husbands: Celina was publicly humiliated when her husband began a relationship with a cupletista, while Nicolás, in the privacy of their bedroom, shamed and bullied Clotilde. Both women saw an opportunity for revenge. Clotilde's was opportunistic and private, made possible by her angelic role. Just as she was forced into her husband's trousers and admonished, Nicolás's illness allowed her to impose a similar humiliation on him. Celina has adopted a different attitude. She has made up her mind that no matter what society may think, she is seeking revenge on Tomás. She has determined that she will humiliate him as publicly as he humiliated her by taking up the role that he appeared to find more appealing - if it was cupletistas that Tomás preferred, then she would become one too.

\section{¿Fueron felices y comieron perdices?}

The final three stories_- "La novia fiel”, "El encaje roto" and "La boda”-all concern courtship or marriage, and in each narrative the protagonist is confronted with an unforeseen difficulty. None of the women will marry the man they had initially hoped to marry. In fact, in these stories, only one of these women will marry at all. Each female protagonist has a sudden insight into the man they love, or thought that they loved. In “La novia fiel”, Amelia's sudden cognisance of her fiancé’s behaviour forced her to reconsider their future marriage; Micaelita, the protagonist of "El encaje roto", realises as she observes a brief change in her groom's expression that her impending marriage will, in all probability, never be happy; and Damián's sudden appearance at Regina's wedding reception and his revelation about his earlier 
behaviour caused Regina's longing for him to instantly turn to contempt and anger, opening up the possibility of real happiness with her new husband.

For young women in fin de siècle Spain marriage was one of the few times when they might be able to exercise agency. Here Pardo Bazán has created three female characters who do choose to act independently before, during or after the occasion. They each exert their own agency and make their own decision as to the outcome of the relationship. In two of the stories, "La novia fiel" and "El encaje roto", they act in a manner that is against the expectations of their parents, the Church and societal norms. These two novias decide that remaining single would be a far better option than a life as a betrayed or beaten wife. The third, Regina in "La boda", realises at the last minute how lucky she is to have avoided a man who uses his charm and amorous attentions for his own ends, and acts accordingly.

\section{"La novia fiel"}

"La novia fiel" continues the pattern of being read as upholding patriarchal values, but also allows for an alternate reading which will expose the by now familiar fin de siècle problem of the moral double standard. This tale also includes reference to a daring, almost taboo element for the time-that of female sexuality. In this story, Amelia Sirvián, the novia of the story's title,breaks her ten-year engagement to her fiancé Germán Riaza because of his continuing unfaithfulness to her during this period. Pardo Bazán reinforces the extent to which this double standard permeated Spanish society by including a clergyman's wholehearted acceptance to the "right" of men to be unfaithful to their women. 
"La novia fiel" begins with a desenlace anticipado (1: 43). A synopsis of the story is given by the third-person omniscient narrator in the opening sentences, noting the brief facts of Amelia and Germán's failed relationship, the shock of the news among the community and states that "[s]ólo el confesor de Amelia tuvo la clave del enigma" (501). This is sufficient to outline the plot; the intrigue, for the reader, as Paredes Núñez notes, is in the development of the plot (1: 43).

The story itself is both simple, and, in many ways unsurprising, when the social mores of the time are recalled. Germán had proposed to Amelia the first time that they met—some ten years previously—and she longed to be married, waiting patiently and chastely, first while he finished his studies and later when he, perhaps somewhat deliberately, took his time establishing himself as a lawyer. The first six years of the engagement, when Germán was studying at Compostela "fueron encantadores" for the couple. However when he spent a year in Madrid, still studying, their relationship altered (1:305).

For Amelia this time was an “i[a]ño de prueba para la novia!" Letters from Germán were infrequent and brief, but far more disturbing were reports from Amelia's friends about his wonderful social life with his female acquaintances in the capital (1:305). However, when he returned, Amelia soon forgot her doubts and the relationship continued apparently unchanged, with the couple reaching an agreement that they would be married when Germán secured permanent employment (1:306). Intentionally or otherwise, for the next year or so no permanent job eventuated, and Germán developed an interest in local politics, which meant that they saw each other much less frequently. Amelia "se lamentaba de esto" but to no avail and, as their relationship was under Germán's absolute control, the 
wedding would be when he decided, "así que se lo permitiesen las circunstancias" (1: 306). By the time that they had been engaged for nine years Amelia was in turmoil. In “Knowledge, Desire and Syntactic Empathy in Pardo Bazán’s 'La novia fiel” Tolliver has made an exhaustive study of the syntactic structures used in this narrative. She argues that the gender-based societal assumptions regarding sexuality, of masculine activity contrasting with feminine passivity, are at the heart of this story. A criticism of this attitude is encoded linguistically in the narrator's discourse, through the interplay of the active and passive syntactic modes (909). Although the story is ostensibly about Amelia and her engagement to Germán, Tolliver has noted that an analysis of the syntax of the story shows that during the courtship and engagement period Amelia has been consistently posited as a syntactic object. Germán has been active; he is the one who has been pursuing his academic (and physical) desires. He has made all the decisions that affected them as a couple-to marry Amelia, to go to Madrid, to set up his business, to delay the marriage itself, while Amelia has simply been waiting for Germán, and waiting to be married.

Throughout the courtship Amelia is the object of the verbs. It is only when she fell ill and struggled to understand her feelings and the truth about Germán and their future together that she changed. She had her own thoughts, made her own decisions, and carried them through with positive actions. After her illness Amelia is the subject of the verbs. She recognised her feelings for what they were, she was able to tell her parents that the relationship was over and to organise for Germán to be informed. And, in addition, she was able to confront the priest with the truth about herself and about Germán, standing up to him and justifying her stance when he tried to demean her. 
Nothing in Amelia's life was, or ever had been, under her own control.

Germán was attracted to her appearance, proposing to her "cuando la pusieron de largo" without ever having had a proper conversation with her (1: 304). Tolliver draws our attention to the passive construction of "la pusieron de largo". It is the parents who decide when their daughters attend these events and the parents who dress them appropriately, like a child, or a doll, Tolliver comments, rather than the young women making these decisions for themselves ("Knowledge” 910). It was Germán who decided when they met during the period of their engagement, and it was his decision to postpone the wedding. A woman as a passive object under the domination of a man was the accepted societal norm, and this portrayal of Amelia is another factor that would have enabled the story to appear unremarkable to a conservative reader.

As the story develops, Amelia's position changes. The almost ten-year wait broke her emotionally and, yearning to be married, she fell into a decline. Somewhat unsure of exactly why she was behaving as she was, Amelia "mostrábase llena de rarezas y caprichos, ya riendo a carcajadas, ya encerrada en hosco silencio. Su salud se alteró también; ... además sufría aflicciones al corazón y ataques nerviosos” (1: 306). Then, without needing to have anybody explain her feelings to her, "con precisión impúdica" she came to the instinctual realisation that she was longing to be married, that "[s]u mal no era sino deseo, ansia prisa, necesidad de casarse" (1: 306). As a young woman with "nociones de honor y honestidad ... que le inculcaron desde la niñez", the realisation of her sexual frustration embarrassed Amelia. Then she began to wonder how Germán, who, she reasoned, had waited as long as she had to be married, had remained so calm and relaxed (and, it must be added, so loath to 
set a wedding date). As she pondered this, suddenly, she saw the light: "[E]n su alma relampagueaba la terrible noción de la realidad ... una carcajada sardónica dilató sus labios, [y] rogó a sus consternados padres que advirtiesen a Germán que las relaciones quedaban rotas" (1: 306-307).

The prevailing societal explanation for Amelia's behavioural "abnormalities" was hysteria. It was officially recognised in the late 1870 by the French psychoanalytic clinician Jean-Marie Charcot (1825-93) and was, of course, not confined to Spain. However the diagnosis of hysteria was used by Spanish proponents of the ángel del hogar model to confirm their beliefs in the hypersensitivity of the female nervous system and therefore a woman's unsuitability for anything other than the hogar. Concealment of the existence of female sexual desire was included within this term as it was believed that this desire was diffused into the nervous system and sublimated into motherly love. This tendency towards hysteria, the bursting out of the sublimated and repressed energy, "accounted for" a woman's need to be protected by a man, and prevent female access to education and the professions. Hysteria was a socially constructed category operating "in the realm of ideology to exercise control ... by those who define the category" (Aldaraca “Medical" 401-405, 411).

Despite being questioned by everybody about her extraordinary decision, Amelia told nobody, except Father Incienso, her confessor, of her reasons for not marrying Germán. ${ }^{25}$ Father Incienso's reply illustrates the deep-seated acceptance of

\footnotetext{
25 Three of Pardo Bazán’s short stories, "El señor doctoral", "Causística” and "La novia fiel”, feature Father Incienso, and it is quite possible that this is the same character who appears in Pardo Bazán's novels Doña Milagros (1894) and Memorias de un solterón (1896) Hemingway notes that Incienso's "very name smacks of irony" and, in Doña Milagros, he is more concerned for his own reputation than he is about Argos, the girl under his spiritual direction (122). Gilmour, in her analysis of Memorias de
} 
the double standard in Spain. He told her that she had made a mistake in leaving Germán, and explained to her that men, including her fiancé, found these sexual escapades enjoyable. Male adultery had become normalised, an accepted and acceptable facet of life in nineteenth-century Spain. However, as for Amelia herself and her imaginations.... A series of ellipses breaks his reply to Amelia, but the reader is left with no doubts that she is the one at fault (307). Amelia's final words of protestation make it clear that she, who for ten years waited patiently and chastely for marriage, should not be seen as the one who has erred. She has not erred yet, but if the situation continues it is likely: “Si no le dejo...le imito!" she tells the priest (1: 504). By acting in this way, and for possibly the first time in her life, Amelia exerted her own agency and was able to remain true to herself (McKenna 56). Yet, despite the apparent positioning of Amelia not as a submissive betrothed girl but as a woman truly in charge of her life, Pardo Bazán, by the use of the subtle syntax, has written a story which may also be read as reflecting the socially acceptable status quo.

The priest's patriarchal attitude towards Amelia is not surprising. With his enthusiastic endorsement of Germán's sexual behaviour he personifies the behaviour that Pardo Bazán, somewhat scathingly, identified in the clergy as being all too ready to advise a woman to submit to the authority of the male, rather than protesting or struggling to express her own viewpoint (Pardo Bazán “Women” 884, 886). It was a view that the Spanish Church had upheld for decades and, as Tolliver remarks, it was considered perfectly acceptable male conduct ("Knowledge" 915). arrogant, intolerant misogynist" (198-99). This same assessment is valid in "La novia fiel". 
However, the second issue that is considered in "La novia fiel", that of female sexuality, was considered quite radical. Pardo Bazán uses different literary techniques in this story, which allow her to avoid direct confrontation with more conservative readers. One is the use of elliptical omissions, which have the effect of disrupting the text and allowing the reader themselves to provide "missing dialogue" (McKenna 56). A second is the "desenlace sugerido", where the narrative ceases with the final dialogue in the confessional left unresolved, and again the reader is left to ponder the ultimate outcome-a technique which, according to Paredes Núñez, serves to intensify the drama of the story (43).

The ending of the narrative, however, is ambiguous. In stating " ¡Si no le dejo ... le imito!" was Amelia implying that she would willingly enter into a premarital sexual relationship with Germán? Or that she would find another man? Society's acquiescence to the double standard and its focus on marriage and motherhood for women left Amelia, now single and in her twenties, with few options. She herself ruled out the possibility of asking her parents for a prompt marriage and, perhaps unwittingly, with her action of casting Germán aside, brought "scandal" to her name. The text gives no indication whatsoever of an interest in any other man, and leaving the relationship in order to suppress her sexual longings would be consigning herself to a life of spinsterhood. Her natural longings for marriage, may well now never be fulfilled. In "La novia fiel” Pardo Bazán has vividly illustrated the emotional destruction that the widely accepted, but insidious, moral double standard inflicted on many Spanish women. Amelia exercised her agency in breaking her engagement. In doing so, she has been able to stand by her own values, but she has also negated 
her chances to reach what she truly desires, a normal, loving, marital relationship. Although she has won on one front, she has lost on another.

"La novia fiel" provides another example of a short story, accepted for a literary magazine and able to be read by even the most conservative reader as upholding social mores, but it can also be shown to contain the possibility of a very subversive feminist point of view. This story offers one woman's answer to the "monstruoso Jano", all too prevalent in Spanish society. It is a radical answer, casting aside an otherwise apparently suitable man, and it would not be every woman who would choose to do this. Many women would not be able to afford to act in this way, simply on economic grounds, even if the idea appeared attractive. Nevertheless, Amelia is a character who has demonstrated that a woman is able to exert her own agency, although in this case, as in "Champagne" there is a high price to be paid. It is also a story in which Pardo Bazán is able to show, through the character of the priest, how the church supported the gender bias of fin de siècle Spanish society.

\section{"El encaje roto"}

This is another subversive story, one which obliquely targets chaperoned engagements, threats of domestic violence and the lack of autonomy and selfdetermination for young women. It also reinforces the hardly surprising fact that, with sufficient wealth, a girl who has decided to remain single can lead an acceptable, comfortable life, whereas, as we have seen in "Champagne" and "Náufragas", women with no independent means were often forced into servitude or prostitution in order to survive. 
Micaelita Aránguiz, in many ways, was fortunate at having been being born into an affluent bourgeois family whose expectation was that their daughter would marry well, with a sumptuous wedding ceremony and reception. Micaelita's courtship with Bernardo de Meneses, a man whom she liked very much, progressed to the point of marriage. Her only concern was vague murmurings that "algunas personas le jugzaban violento" (1: 331). However, due to the close chaperoning of their relationship and, despite several attempts to elude it, she had no way of truly testing him in this matter. His behaviour when he was with her was always impeccable.

The narrative is framed, with the un-named female embedding narrator, ${ }^{26} \mathrm{a}$ friend of Micaelita's, informing the reader of the shocking fact that Micaelita had walked away from the altar before assenting to her union with Bernardo. As in "La novia fiel", the desenlace anticipado sets up a mystery story where the interest for the reader is in the development of the narrative and, in this case, learning exactly what happened at this scandalous ceremony. The narrator had been invited to but had not actually attended the wedding, and all of her knowledge of it had come from hearsay or gossip, which, for quite some time afterwards, was plentiful. The event in the narrative is drawn only from this hearsay and the fact that all weddings were very similar, following a script decreed by society, in which the bride herself was a passive participant (Tolliver "Torn" 238). More than half of the narrative is given over to describing the event as the narrator imagines it to have been-sheaves of roses, white lilac and orange blossoms, the bridesmaids' turquoise bracelets, the medals

\footnotetext{
${ }^{26}$ The gender of the narrator is evident from the use of the feminine form "Convidada", the first word of the text (Tolliver Cigar 70).
} 
and jewels worn by the guests and the bride herself, bejewelled and swathed in silk and tulle.

The bride, however, had a reason to refuse to assent to the marriage vows, and this is revealed when the embedding narrator unexpectedly meets Micaelita three years later and she relates her side of the story. "El encaje roto", like “Champagne”, is unusual, among Pardo Bazán's short stories, in that the embedded narrator, Micaelita, the protagonist, is telling her own story. Arguably, "El encaje roto" is also unique in that it has a doubly female narration, with both the embedding and embedded narratorial voices being female-voiced. Bernardo, Micaelita said, had given her a family heirloom, a strip of antique lace to drape on her wedding dress, emphasising the monetary value of the heirloom, a mercenary touch which irked her. As she was walking towards the altar, she fantasised about how this lace, which appeared so fragile was strong and seemed to symbolise their future life together. Suddenly the lace caught on the door and ripped. Bernardo was looking at her as this happened and everyone present, she thought, would have seen the look on his face, “contraída y desfigurada por el enojo más vivo; sus pupilas chispeantes, su boca entreabierta ya para proferir la reconvención y la injuria” (1: 333).

At that moment her joy was overtaken by profound horror and she realised that the rumours about Bernardo's character and his tendency to violence were indeed justified. She further realised that she did not want to marry a man capable of such an outrage over what was, to her, a minor incident. And so, a few minutes later when the bishop asked Micaelita to commit herself forever to this man, "la verdad 
me saltó a los labios, impetuosa, terrible”, she told her friend, adding (that) "[a]quel ‘no' brotaba sin proponérmelo; me lo decía a mí propia...” (1: 333).

The reason for keeping her refusal to herself until that conversation at the spa, Micaelita claimed, was because it seemed so commonplace and ordinary, not a "serious" reason to walk away from Bernardo at the altar. It may have been difficult for Micaelita to explain that she refused to be married because of a momentary change of expression on Bernardo's face. However this expression confirmed something to Micaelita that was indeed serious - that reports of his violence had validity. The accepted societal practice of chaperoned engagements for the majority of couples had not allowed any real opportunity to discover the truth of her suspicions that her marriage could be unhappy.

Micaelita's split-second decision had certainly opened her to the ubiquitous el qué dirán, but it would appear to have saved her from a lifetime of domestic misery as marital violence in Spanish society was all too common. ${ }^{27}$ She decided, in that second, that a propensity to violence mattered, whereas public opinion did not and, by rejecting marriage to a violent man, she took her life into her own hands.

\section{"La boda"}

Regina, the protagonist of "La boda" was an uncommon, somewhat romantically inclined young woman, able to make her own decisions and resolutely carry them through. She was also fortunate in many respects, being well-educated and well-

\footnotetext{
${ }^{27}$ In Un viaje de novios (1881), Pardo Bazán portrays the accepted norm of domestic violence being a husband's "right" when Aurelio Miranda speaks about his wife Lucía: "Yo la abo... la abofeteo, porque pu... pu... puedo y me da la gana... Soy su marido" (441). Despite this attack the priest, Father Arrigoitia, says that Lucía cannot legally leave Aurelio because "iNo separe el hombre lo que Dios ha unido! Él volverá, volverá al lado de su esposa..., no lo dude usted" (448).
} 
read, not only in romances, but also in history and poetry. In addition, she had an "afición al teatro, insaciable; no al teatro alegre ni al sicalíptico: a los dramas y a las comedias serias y sentimentales" (3: 109). "La boda" is a story which invites the reader to consider the way in which a good education and a worldview beyond the domestic sphere influences female decision-making. It also alludes to the fact that a parentally-arranged marriage may, in the end, be a far better outcome for a young woman than a love-match where, as illustrated in "El encaje roto", the couple have no opportunity before the marriage to know each other's characters adequately.

Regina was not just educated, she was also attractive: a young woman who "[n]o pasaba inadvertida en ninguna parte, y tenía sus envidiosas y sus imitadoras" (3: 109). However, she was a girl with a certain romantic temperament which, perhaps, led to the fact that her life was dominated by her secret infatuation with her French teacher, Damián Antiste, (3: 109). Unfortunately, in Regina's eyes, Damián appeared to be completely unaware of her feelings and she was devastated when she noticed him discreetly passing notes to one of his richer students. Despite her still being of school-age, her mother was making arrangements for her to be married to Elías, an older man who was both "bien rico y generoso" and "bien pirrado estaba por la novia" (3: 109). ${ }^{28}$ Initially, Regina refused to accept Eliás as her suitor due to her all-consuming passion for Damián. However, when Regina reluctantly accepted that Damián was interested in her classmate rather than herself, she felt humiliated and disillusioned with "su amor muerto, su desengaño, paloma de blancas alas, rotas y sangrientas...” and she agreed to marry Eliás after all (3: 110).

\footnotetext{
${ }^{28}$ The age of consent in Spain at that time was 13 years. It was only in 2015 that it was raised, to 16 years <www.bbc.com/news/world-europe-33636920>.
} 
The narrative is a conventional third-person omniscient account with the opening paragraph in medias res, as Regina and Eliás's wedding guests arrived for the reception. The analepsis which follows provides the necessary background for the reader to understand the events of the next few minutes which make up the body of the story. As Regina and Elías arrived at their wedding reception they stepped from the bus and Damián suddenly appeared beside them. He had not been invited to the church ceremony but, Regina concluded, he had somehow inveigled himself into the reception gathering. He moved quickly, taking Regina's hand to help her alight before Eliás could and she felt that Damián's eyes "la devoraban" (3: 110). Regina looked radiant, and she knew it. She had triumphed, she thought.

Somewhat unexpectedly the wedding party separated for a few minutes and Regina took the opportunity to be alone with Damián, sheltered by some trees. In her excitement of being so close to him, she swooned but, on coming to, she realised, with shock and astonishment, what Damián was saying to her. He had known all along of her infatuation, he said, and now he was laughing at her feelings for him and mocking her. In an instant she realised that Damián was not the man she had imagined. She was astounded and embarrassed at first, then contemptuous and finally furious. She responded vehemently: “¡Miserable!' La palabra asomó a los labios, blancos de cólera. —iMiserable! — gritó en alto” (3: 111). Regina returned immediately to the reception, sought out her new husband and told him tenderly: "Mira que quiero sentarme a tu lado, ¿eh?” (3: 111). Throughout the luncheon Regina was "tierna [e] insinuante" towards him and Elías, for his part, was "loco de alegría" (3: 111). 
According to Hoffman, Regina realised that she had been manipulated by Damián and she, in turn, manipulates Elías, who at this point she does not love. Regina's actions in choosing to sit next to her husband and acting kindly towards him, Hoffman argues, show that she has chosen power over passion (“Transformations" 243-44). However, I would argue that "insinuante" has at least two other shades of meaning, "flirtatious" and "suggestive", either of which would not put Regina in quite such a cold, calculating light as Hoffman's suggestion. Regina is well educated and in all probability has learned to think for herself and to sum situations up quickly. An examination of the text fails to reveal anything negative at all about Elías. Quite apart from the fact that he was moneyed, he is described as generous and despite Regina's cold and offhand manner towards him-indeed, she had never uttered a kind word to him-he appeared to love her. Regina would have realised these facts and, although he may have seemed old to her, as a teenager, he gave every impression that he was a good man. Her romantic idealism concerning Damián has just failed her miserably and I argue that Regina was wise enough and quick-thinking enough to realise that it was now up to her to make this new marriage work for her future happiness. By the time that she returned to the wedding reception and joined her new husband she began on this new journey, a journey based on realism, not romanticism. Few, if any, of the stories examined here have "happy endings", but "La boda" at least offers the reader the distinct possibility that Regina and Eliás's marriage will be successful.

Pardo Bazán has created these five protagonists who, against the mores of their society, exercise agency. Some publicly, others privately, some spontaneously, others in a premeditated fashion. In each of the stories (and, in fact, in common with 
the previous seven stories) Pardo Bazán has produced a narrative that allows for a reading which conveys a subversive feminist message to her readers. Each story, to use her own metaphor, represents another foothold for her in the slow climb towards Spain's reclamation of "la reivindicación de los derechos de la mujer" (Pardo Bazán “Sobre “ Gómez-Ferrer 259). 


\section{Conclusion}

The focus of this thesis has been to demonstrate that Pardo Bazán's feminist opinions, which she articulated overtly in her essays and a few of her novels, are present, either directly or indirectly, in many of her short stories. Pardo Bazán was a self-proclaimed, lifelong Catholic and possessed both a strong sense of equality and of social justice, particularly in regard to the inferior social status of women in Spanish society, in addition to a dismissive attitude towards the prevailing Angel in the House construct.

As I have discussed throughout this thesis, she developed her own writing style to convey her opinions. The style which she adopted most frequently, that of using a male-voiced narrator, was unusual for a woman of her time. However it made her able to "transcend her gender and become ... an author, critic and public figure in the world of letters" (Bieder "Literature" 49).

Mastering the art of essay writing, Pardo Bazán propounded her views clearly and forcefully to her readers in literary essays published in a variety of magazines and newspapers. Her views on the education system, the law, the patriarchal attitude of the Catholic Church, the domination of the male in the marriage relationship, the gendered double standards operating in society and the lack of vocational opportunities for women were clearly and directly articulated. Each of the twelve stories that have been analysed can be read in line with the mores of fin de siècle Spanish society. However each one can also be read against the grain as mirroring a feminist subtext concerned with issues that Pardo Bazán raised in her essays. In 
contrast to her essays, the short stories studied here proffer an implicit rather than an overt feminist message. As a general rule, solutions to problems raised are not offered. The plight of the female protagonist is presented and it is left for the, mainly male, reader to discover the alternate readings and possible solutions as Pardo Bazán's readers were men who had the power to create the social change which they deemed necessary.

Much of Pardo Bazán’s fiction, both novels and short stories, was set largely in Galicia, with which she was familiar. Two stories from the third chapter, "El indulto" and "Las medias rojas", demonstrate her knowledge of and feeling for Galician campesinos; they both feature poor illiterate women facing domestic violence and entirely at the mercy of the men around them. Both use a male-voiced third person narrator, but still allow for alternative readings that draw attention to the subsistence-level lifestyle faced by many agricultural workers, the level of domestic violence in many households and the difficulties faced by illiterate women in legal matters. Describing the emigration agent in "Las medias rojas" as a "gancho" also gives a glimpse of the perils of emigration for young, pretty women, who may not realise that an "advance payment" to them may, in reality, constitute a commitment to prostitution at their destination. Both stories underline the ultimate lack of agency for campesinas; men control all aspects of their lives.

Inadequate female education and the lack of employment for women outside their family environment are among the issues raised by the texts of "Champagne" and "Náufragas". Pardo Bazán commented that in Spain it is said that "only two professions are open to women, that of tobacconist, or that of queen [while for] men, on the other hand every path lies open" (Women” 888). However, it is doubtful if 
either of these professions would spring to mind as possibilities for a poorly educated woman alone in the world. The two stories illustrate the speed with which a woman can lose her security, through widowhood or separation, leaving her penniless and vulnerable in the world outside her domestic sphere. The unnamed protagonist of "Náufragas" failed to obtain a housekeeping position for herself and her daughters, while the (also unnamed) protagonist of "Champagne" was simply desperate to leave the family home in the wake of a marital disgrace.

In both stories prostitution appeared to be the only solution. In "Náufragas" the teenage daughter would support her mother and sister, while the protagonist of "Champagne" has made the best of her life, appreciating the autonomy that she has achieved, although the reader is left pondering the cost to her. The issue of arranged, all but forced marriage for girls is also raised in "Champagne", where the protagonist was viewed almost as a chattel which could be handed on to a husband as she was becoming a nuisance for her step-mother. This narrative is notable for being one of Pardo Bazán’s very few which use a female voice, enabling the female protagonist to tell her own story. None of these women is able to exert any agency in their lives, although the protagonist of "Champagne" does appear relatively satisfied with her present position.

Gendered double standards were anathema to Pardo Bazán. Over two pages of "The Women of Spain" are devoted to her critique of the lack of piety in the male Spaniard's life, while still demanding an adherence to a true Catholic faith from their wives (884). As a practising Catholic, Pardo Bazán was not asking for the right of women to be free thinkers, but rather, that men be held to the same standards of behaviour. "Los huevos pasados" illustrates the gulf that could exist between males 
and females in this regard. It is one of Pardo Bazán's few humorous stories, the humour coming at the expense of the protagonist Sr. López as he unwittingly puts himself in the position of having to recite the Creed, an important tenet of the Catholic faith, in front of his daughters. It is a short, gentle story but, by making the father look something of a fool, it achieves its purpose of emphasising the gender bias in this area, with the male demanding a standard of belief and behaviour from the woman that he sees no need to accept for himself.

Pardo Bazán reserves her true venom for the all too prevalent, socially acceptable, church-sanctioned, moral double standard. Men, she says in her essay "La educación del hombre y de la mujer", are duplicitous and two-faced like Janus. One face, that of the attentive caring family man, is mocking and hypocritical, the other is laughing behind his wife's (or fiancée's) back while seeking "pleasure and distraction abroad” (Pardo Bazán “Women” 884). It applied, however, to all amorous relationships. Spanish society demanded sexual purity from a woman before marriage, while the man himself, as we have seen in "Sor Aparición" and "La culpable”, was able to seduce a young marriageable woman, seemingly without consequence to himself, and had no shame about allowing the woman to bear the life-long consequences of his pleasure seeking. These two stories uncompromisingly convey Pardo Bazán's distaste for this gendered double standard.

Nevertheless, some women did retaliate against philandering husbands, and Pardo Bazán has represented a particularly spirited attempt in "Paracaídas". The protagonist Celina discovered that a married woman was hampered legally if she wished to exercise her agency and leave her marriage with dignity, so instead of pretending to be a submissive and forgiving wife, as was expected of her, she opts for 
publicly shaming her husband. Private retaliation, although for bullying rather than adultery, was Clotilde's option in "Feminista", a wryly humorous story which reflects Pardo Bazán's views on patriarchal expectations and female submission in the marriage relationship.

Some of Pardo Bazán's views on marriage itself are included in the final three stories. Two feminist topics are raised in "La novia fiel": the moral double standard, and the Church's acceptance and endorsement of this, and the practically taboo matter of female sexuality. We have already noted Pardo Bazán's views on the double standard while her condemnation of the Church on this matter is clearly spelt out in “The Women of Spain” $(884,886)$. The protagonist of the story, Amelia, has taken a strong stand against her unfaithful novio by breaking off the relationship altogether but, again, at a great cost to herself.

Micaelita, in "El encaje roto" also had the courage to not marry her fiancé, but for a very different reason-the suspicion that her future huband had a tendency to violence. The dangers to the women from chaperoned engagements, with their inherent risk of "surface" conversations rather than frank discussions, and the lack of autonomy and self-determination for young women are incorporated in the subtextual reading. As in "Champagne, Pardo Bazán has used a feminine voice, enabling Micaelita to tell her own story. Both women have used their agency to make lifechanging decisions for themselves. The final story considers the value of a good education for girls and a worldview beyond the domestic influence, as factors which facilitate good decision making. It also offers the possibility of happiness for a woman in a parentally arranged marriage. It is the only one of these stories where marriage is discussed, to do so. 
I argued that each of these stories analysed here offers a reading which raises feminist issues, the majority of which I have correlated with statements taken directly from some of Pardo Bazán's published essays or other works. While I have highlighted the strong female characters who were, in many cases, willing and able to challenge and subvert the Spanish patriarchal society, I have also drawn attention to other, less fortunate women who succumbed to the gender-based injustices of Pardo Bazán's society. I have shown that each of the twelve selected stories can be read as having a feminist sub-text. By illustrating and problematising different aspects of the difficulties which faced many Spanish women, Pardo Bazán has been effective in disseminating, albeit at times subversively, her feminist views to a broader audience who might otherwise have been reluctant to consider such matters. 


\section{Bibliography}

Alberdi, Inés. Vida de Emilia Pardo Bazán. Eila, 2013.

Aldaraca, Bridget A. "El ángel del hogar: The Cult of Domesticity in NineteenthCentury Spain.” Theory and Practice of Feminist Literary Criticism. Edited by Gabriela Mora and Karen S. Van Hoof, Bilingual Press, 1982, pp. 62-87.

---. "The Medical Construction of the Feminine Subject in Nineteenth-Century Spain.” Vidal, pp. 395-413.

---. El ángel del hogar: Galdós and the Ideology of Domesticity in Spain. U of North Carolina P, 1991.

Álvarez Junco, José. “The Debate over the Nation.” Townson, pp. 18-41.

Arenal, Concepción. La mujer en su casa. Madrid, 1883. Google Books.

<https://books.google.com>. Accessed 25 May 2017.

---. La mujer del porvenir. Madrid, 1884. Google Books. <https://books.google.com>. Accessed 25 May 2017.

---. "La educación de la mujer.” 1896. NoBooks Editorial, 2015. $<$ www.nobooksed.com>. Accessed 1 April 2017.

Bieder, Maryellen. “En-gendering Strategies of Authority. Emilia Pardo Bazán and the Novel." Vidal, pp. 473-96.

---. "Plotting Gender/Replotting the Reader: Strategies of Subversion in Stories by Emilia Pardo Bazán.” Indiana Journal of Hispanic Literatures, vol. 2, no. 1, 1993, pp. 137-57. 
---. “Emilia Pardo Bazán and Literary Women: Women Reading Women’s Writing in Late $19^{\text {th }}$-century Spain.” Revista Hispánica Moderna, vol. 46, no. 1, 1993, pp. $19-33$

---. "Women, Literature, and Society: the Essays of Emilia Pardo Bazán." Glenn and Mazquiarán de Rodríguez. 1998, pp. 25-54.

Blanco, Alda. "Domesticity, Education and the Woman Writer." Vidal, pp. 371-93.

Bravo-Villasante, Carmen. Vida y obra de Emilia Pardo Bazán. Occidente, 1962.

Brown, Donald Fowler. The Catholic Naturalism of Pardo Bazán. U of North Carolina P, 1971.

Burgos, Carmen. El divorcio en España. Madrid: Romero, 1904. Google Books. <https://books.google.co.nz>. Accessed 1 April 2017.

Carr, Raymond. Spain 1808-1975. Clarendon Press, 1982.

Charnon-Deutsch, Lou. The Nineteenth-Century Spanish Short Story: Textual Strategies of a Genre in Transition. Tamesis, 1985.

---. "The Making of a Mass Media in Spain." Nineteenth Century Prose, vol. 32, no. 1, 2005, pp. 186-226.

Clèmessy, Nelly. Emilia Pardo Bazán como novelista (de la teoría a la práctica). Translated by Irene Gambra, Fundación Universitaria Española, 1981. 2 vols. Cornide Ferrant, Enrique. Mujeres estelares en la cultura gallega. Diputación Provincial de A Coruña, 1993.

Faus, Pilar. Emilia Pardo Bazán: su época, su vida, su obra. Fundación Pedro Barrié de la Maza, 2003. 2 vols.

Feeny, Thomas. “Pardo Bazán’s Pessimistic View of Love as Revealed in ‘Cuentos de amor”. Hispanófila, vol. 64, 1978, pp. 7-14. 
Furst, Lilian R. Realism. Longman, 1992.

Gaisor, Bonnie L. “The Economy of the Feminine in Emilia Pardo Bazán’s ‘Las medias rojas'” Hispania, vol. 9o, no. 4, 2007, pp. 747-54.

Garza, Efraín E. La reivindicación de los derechos de la mujer en diez cuentos de Emilia Pardo Bazán. Alexandria Library, 2013.

Gilbert, Sandra and Gubar, Susan. The Madwoman in the Attic: the Woman Writer and the Nineteenth-Century Literary Imagination. Yale UP, 1979.

Gilmour, Nicola M. Transvestite Narratives in Nineteenth-and Twentieth-Century Hispanic Authors: Using the Voice of the Opposite Gender. Edward Mellen, 2008.

Glenn, Kathleen M. and Mazquiarán de Rodríguez, Mercedes. Introduction. Glenn and Mazquiarán de Rodríguez, pp. 1-5.

---. Spanish Women Writers and the Essay: Gender, Politics, and the Self. U of Missouri P, 1998.

Glos, George E. “The Spanish Divorce Law 1981.” The International and Comparative Law Quarterly, vol. 32, no. 3, 1983, pp. 667-88.

Goldar, Ernesto. "La 'mala vida'." Buenos Aires 1880-1930: La capital de un imperio imaginario. Edited by Horacio Vázquez-Rial, Alianza Editorial, 1996, pp. 22853.

Gómez-Ferrer, Guadalupe. Introduction. La mujer española y otros escritos. Cátedra, 1999, pp.

Hemingway, Maurice. Emilia Pardo Bazán: The Making of a Novelist. Cambridge UP, 1983. 
Hernández, Juana Amelia. “Arenal, Concepción (1820-1893).” Pérez and Ihrie, pp. 3033.

Hilton, Ronald. “The Centenary of Emilia Pardo Bazán.” Books Abroad, vol. 26, no. 4, 1952, pp. 345-47.

Hoffman, Joan M. “Torn Lace and Other Transformations: Rewriting the Bride’s Script in Selected Stories by Emilia Pardo Bazán.” Hispania, vol. 82, no. 2, 1999, pp. 238-45.

---. “Ángel del hogar.” Pérez and Ihrie, 27-28.

Irizarry, Estelle. “Concepción Arenal and the Essay of Advocacy”. Glenn and Mazquiarán de Rodríguez, pp. 6-24.

Jagoe, Catherine. Ambiguous Angels: Gender in the Novels of Galdós. U of California P, 1994 .

---. "La enseñanza femenina en la España decimonónica." La mujer en los discursos de género: textos y contextos en el siglo XIX. Edited by Catherine Jagoe et al., Icaria, 1998, pp. 105-46.

Kirkpatrick, Susan. Las Románticas: Women Writers and Subjectivity in Spain 18351850. U of California P, 1989.

Lanser, Susan Sniader. The Narrative Act. Princeton UP, 1981.

---. “Toward a Feminist Narratology." Style, vol. 20, no. 3, 1986, pp. 341-63.

Lehan, Richard. “American Literary Naturalism: The French Connection.”

Nineteenth-Century Fiction, vol. 38, no. 4, 1984, pp. 529-57.

León, Fray Luis. La perfecta casada. Madrid, 1583. Biblioteca Virtual Miguel de Cervantes. <www.cervantesvirtual.com>.

Llorca Baus, Carlos. Los barcos de la emigración 1880-1950. Such Serra, 1992. 
McKenna, Susan M. Crafting the Female Subject: Narrative Innovation in the Short Fiction of Emilia Pardo Bazán. The Catholic U of America P, 2009.

Mandrell, James. "Realism in Spain: Galdós, Pardo Bazán, Clarín and the European Context." Neohelicon, vol. 15, no. 2, 2005, pp. 83-112.

Manjarrés, José de. Guía de señoritas en el gran mundo. Barcelona, 1885.

Nash, Mary. "Un/Contested Identities: Motherhood, Sex Reform and the Modernization of Gender Identity in Early Twentieth-Century Spain”. Constructing Spanish Womanhood: Female Identity in Modern Spain. Edited by Victoria Loreé Enders and Pamela Beth Radcliff, State U of New York P, 1999, pp. 25-50.

Nielfa, Gloria. “Family Law, Legal Reforms, Female Lawyers, and Feminist Claims in Spain 1868-1950”. New Perspectives on European Women’s Legal History. Edited by Sara L. Kimble and Marion Rőwecamp, Routledge, 2017, pp. 55-75. Pardo Bazán, Emilia. “Apuntes autobiográficos”, Los Pazos de Ulloa. Barcelona, 1886, pp. 5-92. Google Books. <https://books.google.com>. Accessed 1 April 2017. ---. “Concepción Arenal y sus ideas acerca de la mujer”. La mujer española, pp.198214.

---. Cuentos completos. Edited by Paredes Núñez, Galicia Editorial, 1990. 4 vols.

---. El viaje de novios. Madrid, 1881. Google Books. <https://books.google.com>. Accessed 1 April 2017.

---. "La cuestión académica”. La mujer española, pp. 75-82.

---. La cuestión palpitante. 1883. Edited by Rosa de Diego, Biblioteca Nueva, 1998.

---."La educación del hombre y la de la mujer”. La mujer española, pp.149-177. 
---. La mujer española y otros escritos. Edited by Guadalupe Gómez-Ferrer, Cátedra, 1999.

---."La mujer española." La mujer española, pp. 83-115.

---."La vida contemporánea”. La mujer española, pp. 276-28o.

---. Obras completas. Edited by Fundación José Antonio de Castro, Biblioteca Castro, 2004 .10 vols.

---. "Sobre los derechos de la mujer". La mujer española, pp.258-267.

---. "The Women of Spain.” Fortnightly Review. 1 June, 1889, pp. 879-904. <www.fortnightlyreview.co.uk>. Accessed 1 April 2017.

---. Torn Lace and Other Stories. Translated by María Cristina Urruela, MLA P, 1996. Paredes Núñez, Juan. “The Feminism of Emilia Pardo Bazán.” Cuadernos de Estudios Gallegos, vol. 40, no. 105, 1992, pp. 303-13.

Pattison, Walter T. Emilia Pardo Bazán. Twayne, 1971.

Pérez, Janet. "Winners, Losers and Casualties in Pardo Bazán’s Battle of the Sexes.” Letras Peninsulares, vol. 5, 1992, pp. 347-56.

---. "Subversion of Victorian Values and Idea Types: Pardo Bazán and the Ángel del hogar." Hispanófila, vol. 113, 1995, pp. 31-44.

---. Pérez, Janet and Ihrie, Maureen, editors. The Feminist Encyclopedia of Spanish Literature. Greenwood Press, 2000.

Prince, Gerald. Dictionary of Narratology. U of Nebraska P, 1987.

Rutherford, J. D. "Realism in Spain and Portugal." The Age of Realism. Edited by F. W. J. Hemmings, Penguin, 1974, pp. 265-322.

Salustio, Doctor. Carta a una joven sobre lo que debe saber antes de casarse. Madrid, 1865. Google Books. <https://books.google.com>. Accessed 3 May 2017. 
Santana, Mario. “An Essay in Feminist Rhetoric: Emilia Pardo Bazán’s 'El indulto’.” $M L N$, vol. 116, no. 2, 2001, pp. 250-65.

Scanlon, Geraldine. La polémica feminista en la España contemporánea. Translated by Rafael Mazarrasa, Akal, 1986.

Showalter, Elaine. "Killing the Angel in the House: The Autonomy of Women Writers." The Antioch Review, vol. 50, no. 1/2, 1992, pp. 207-20.

Sinués, María del Pilar. El ángel del hogar. Madrid: A. de San Martín, 1881. Google Books. <https://books.google.com>. Accessed 1 April 2017.

---. Verdades dulces y amargas: páginas para la mujer. Madrid, 1898. Google Books. <https://books.google.com>. Accessed 5 April 2017.

Thomas, Bronwen. Narrative: The Basics. Routledge, 2016.

Tolliver, Joyce. Cigar Smoke and Violet Water: Gendered Discourse in the Stories of Emilia Pardo Bazán. United U P, 1998.

---. Introduction. Pardo Bazán Torn Lace, pp. ix-xxiv.

---. “Knowledge, Desire and Syntactic Empathy in Pardo Bazán's 'La novia fiel'.” Hispania, vol. 72, no. 4, 1989, pp. 909-18.

---. “My Distinguished Friend and Colleague Tula’: Emilia Pardo Bazán and Literary-Feminist Polemics.” Recovering Spain’s Feminist Tradition. Edited by Lisa Vollendorf, MLA P, 2001, pp. 217-37.

---. “'Sor Aparición’ and the Gaze: Pardo Bazán’s Gendered Reply to the Romantic Don Juan." Hispania, vol. 77, no. 3, 1994, pp. 394-405.

Tortella Casares, Gabriel. The Development of Modern Spain: An Economic History of the $19^{\text {th }}$ and $20^{\text {th }}$ Centuries. Translated by Valerie Herr, Harvard UP, 2000. 
Townson, Nigel. “Anticlericalism and Secularization: A European Exception”. Is Spain Different? A Comparative Look at the $19^{\text {th }}$ and $20^{\text {th }}$ Centuries. Ed. Townson. Sussex Academic P, 2015, pp. 71-101.

Ugarte, Michael. “Carmen de Burgos (“Columbine”): Feminist Avant la Lettre.” Glenn and Mazquiarán de Rodríguez, pp. 55-74.

Varela Jácome, Benito. “Pardo Bazán y su 'Nuevo Teatro Crítico”. Cuadernos de estudios gallegos, vol. 7, 1952, pp. 159-64.

Vidal, Hernán. Editor. Cultural and Historical Grounding for Hispanic and LusoBrazilian Feminist Literary Criticism. Institute for the Study of Ideologies and Literature, 1989 .

Vilar, Pierre. Spain, a Brief History. Pergamon Press, 1977.

Villanueva, Darío, and González Herrán, José Manuel. “Introducciones”. Obras Completas, 10 vols.

Walter, Susan. "The Use of Narrative Frames in Four Tales by Emilia Pardo Bazán.” Hispania, vol. 90, no. 1, 2007, pp. 10-20.

---. From the Outside Looking in: Narrative Frames and Narrative Spaces in the Short Stories of Emilia Pardo Bazán. Juan de la Cuesta, 2009.

Woolf, Virginia. "Professions for Women.” Death of the Moth and other Essays. Harcourt Brace, 1942, pp. 235-42. 


\section{Appendix}

\section{Original Publication Details of the Short Stories}

“El indulto”. La Revista Ibérica (1883), La dama joven (1885), Cuentos de Marineda

(1892), Cuentos completos, vol. 1, pp. 122-27.

“Champagne”. Cuentos de amor (1898), Cuentos completos, vol. 1, pp. 293-295.

“Náufragas”. Blanco y Negro 946 (1909), Cuentos nuevos (2nd ed. 1910), Cuentos completos, vol. 1, pp. 141-44.

“Las medias rojas”. Por esos mundos (1914), Cuentos de la tierra (1922), Cuentos completos, vol. 3, pp. 195-97.

“Los huevos pasados”. Arco Iris (1899), Cuentos sacroprofanos (1899), Cuentos completos, vol. 3, pp. 449-50.

“Sor Aparición”. El Imparcial (1896), Cuentos de amor (1898), Cuentos completos, vol. 1, pp. $295-98$.

"La culpable". El Liberal (1898), Cuentos de amor (1898), Cuentos completos, vol. 1, pp. 303-304.

“Feminista”. Sud Exprés (1909), Cuentos completos, vol. 3, pp. 106-o9.

“Paracaídas”. La Ilustración Española y Americana 3 (1910), Cuentos Nuevos (2nd Ed. 1910), Cuentos completos, vol. 1, pp. 241-4.

“La novia fiel”. El Liberal (1894), Cuentos de amor (1898), Cuentos completos, vol. 1, pp. 304-307.

“El encaje roto”. El Liberal (1897), Cuentos de amor (1898), Cuentos completos, vol. 1, pp. 331-33.

“La boda”. Sud exprés (1909), Cuentos completos, vol. 3, pp. 109-11. 